\title{
THE POLITIGAL JOURNAL OF SIR GEORGE FOTTRELL
}

I3 Jany. I885

I think it may perhaps at some future stage of Irish politics prove useful to have from an eye witness some notes of the events now passing in Ireland or rather some notes of the inner working of the Government and of the Irish party. I have rather exceptional opportunities of noting their working. I have since I attained manhood been a consistent Nationalist and I believe that the leading men on the national side have confidence in my honour and consistency. On the other hand I am a Crown official \& I am an intimate personal friend of Sir Robert Hamilton, ${ }^{1}$ the Under Secretary for Ireland. My first introduction to him took place about I 8 months ago. I was introduced to him by Robert Holmes, ${ }^{2}$ the Treasury Remembrancer. At that time Sir Robert was Mr. Hamilton \& his private secretary was Mr. Clarke Hall who had come over temporarily from the Admiralty. Mr. Hamilton was himself at that time only a temporary official. Shortly afterwards he was induced to accept the permanent appointment as Under Secretary. From the date of my first introduction to him up to the present our acquaintance has steadily developed into a warm friendship and I think that Sir Robert Hamilton now probably speaks to me on Irish matters more freely than to anyone else.

I have always spoken to him with similar freedom and whether my views were shared by him or were at total variance with his I have never concealed my opinion from him.

I was in last October appointed Clerk of the Crown for Dublin City \& County \& I believe my appointment was the result of Sir R. Hamilton's intervention. I had not asked for the post. My first interview with Lord Spencer ${ }^{3}$ was that at which he offered me the post. A note of the conversation on that occasion is in my locked note book which I had when in the service of the Land Commission.

In December I884 Sir R. Hamilton sent for me to ask me my opinion as to the best tribunal to deal for Ireland with the question

See appendix.

${ }^{2}$ Robert William Arbuthnot Holmes (1843-I910), Treasury Remembrancer and Deputy Paymaster for Ireland (1882-I908).

${ }^{3}$ See appendix. 
of Boundaries under the Redistribution of Seats Bill. ${ }^{4}$ He told me his notion was to make the Irish Boundaries Commission out of exactly similar elements to those out of which the Scotch Boundaries Commission $^{5}$ had just been formed, viz. Sir J. Lambert ${ }^{6}$ the Head of the Ordinance Survey Dept., Sir F. Sandford, ${ }^{7}$ the Chief English Boundaries Commissioner \& I barrister.

I agreed in the wisdom of this. He then asked who would be the best barrister \& he said Naish ${ }^{8}$ had recommended Piers White QC. ${ }^{9}$ I cordially agreed.

He subsequently told me he had been asked by Lord Spencer to get me to ascertain my views of Gray $\mathrm{MP}^{\circ \circ} \&$ Sexton $\mathrm{MP}^{\mathrm{in}}$ on the subject $\&$ he asked me had I any objection privately to make the inquiry. I replied that my position of mind was that I would not on any account 'pump' the Irish members \& then detail to the Government anything which I thought the members might wish to conceal nor would I pump him or any other member of the Government \& then detail to the Irish members anything which he might wish to conceal but that I would willingly undertake any trouble with a view of making each side acquainted with the views of the other so as to promote harmony between them.

Gray was in London \& so was Sexton. I saw Tim Healy MP. ${ }^{12} \mathrm{He}$ preferred Carton ${ }^{13}$ to Piers White but he admitted that White would command confidence on all sides for his integrity and high character. I arranged to lunch with Sir R. Hamilton on the following Sunday. When I had lunched he said that Lord Spencer wished to see me. I walked over to the Vice Regal Lodge \& had a long talk about the

${ }^{4}$ Bill for the Redistribution of Seats at Parliamentary Elections: PP I884-5, IV, 85 .

${ }^{5}$ Report of the Boundary Commissioners for Scotland: PP I884-5, XIX, 499.

${ }^{6}$ Sir John Lambert (I8I5-1892), Permanent Secretary to the Local Government Board (I87I-I882).

${ }^{7}$ Sir Francis Sandford (1824-1893), first Baron Sandford (I89I), Secretary for the Education Office (1870-1884).

${ }^{8}$ John Naish (I84 I-I89o), Attorney-General (I884-I885) and Lord Chancellor of Ireland (1885, I886).

${ }^{9}$ A Roman Catholic barrister and liberal, later Chairman of the Liberal Union of Ireland: see Hamilton to Spencer, 5 December i884: AP, Add MS 77o6o; The Times, I5 March I888, p. 9 .

${ }^{\text {10 }}$ Edmund Dwyer Gray (1845-1888), Nat. MP for Co. Carlow (I880-1885) and for St Stephen's Green Division, Dublin (1885-1888), owner of the Freeman's Fournal.

${ }^{11}$ Thomas Sexton (I848-I932), Nat. MP for Co. Sligo (I880-1885) and for Sligo South (1885-1892), Lord Mayor of Dublin (1887-1889).

${ }^{12}$ Timothy Michael Healy (I855-I93I), Nat. MP for Co. Monaghan (I883-1885), for Londonderry South (I885-I886), and for Longford North (I887-I892), Governor-General of the Irish Free State (1922-I928).

${ }^{13}$ Richard Paul Carton (1836-I907), Commissioner of National Education, Chairman of the Queen's Colleges Commission (I884-1885). 
Boundaries Commission. I strongly urged the importance of making the Scotch \& Irish Commissions identical. I told Healy's opinion but I said that personally I had a much higher opinion of Piers White's ability than of Carton's. ${ }^{14}$

On that evening Lord Spencer sent Mr. Courtney Boyle, ${ }^{15}$ his private secretary, specially to London to arrange if possible for the appointment of the Commission on the suggested lines \& the Commission was next day appointed consisting of the following -

Sir J. Lambert - Sir F. Sandford

Piers White QG - Major McPherson ${ }^{16}$

\& Richard Burke [sic $]{ }^{17}$ Local Govt. Board Inspector.

All the Irish papers Whig, Tory \& Nationalist approved of the Commission. ${ }^{18}$

One day in December last Sir R. Hamilton went with me to Bray for a long walk. On our way out in the train we discussed the question of the renewal of the Crimes Act. I opposed its renewal except under the direst necessity. He admitted that his own view was that most of the provisions of the Act might be allowed to lapse but that it would be requisite to re-enact the change of venue clause $\&$ the special jury clause. ${ }^{19}$

I urged the pressing importance of bringing in a County Government Bill for Ireland. He admitted this - we discussed the details as to the multiple vote \& as to giving some supervising power to the Local Government Board. ${ }^{20}$

${ }^{14}$ Spencer informed Sir Charles Dilke, 'From sources independent of Sir R. Hamilton I hear that a row is getting up about the question': Spencer to Dilke, ro December I884: AP, Add MS 76924 .

${ }^{15}$ Courtenay Edmund Boyle (I845-I90I), private secretary to Lord Spencer (I868-I874, I882-I885), Assistant-Secretary to the Local Government Board (I885) and the Board of Trade (I886).

${ }^{16}$ John Cosmo Macpherson (Farquharson) (1839-1905), officer of Royal Engineers (I8591896), Executive Officer of the Ordnance Survey of the United Kingdom (1887-I894).

${ }^{17}$ As inspector for Dublin, Bourke had represented the Treasury in the settlement of arrears. Spencer claimed that he and White were the 'most influential' men available and that their impartiality was guaranteed: Spencer to Edward Gibson, I6, I9, and 26 December 1884, repr. A.B. Cooke and A.P.W. Malcolmson (eds), The Ashbourne Papers, I869-1913: a calendar of the papers of Edward Gibson, Ist Lord Ashbourne (Belfast, I974), pp. I79-I80.

${ }^{18}$ See The Times, 3 December 1884 , p. I2. For findings, see Report of the Boundary Commissioners for Ireland: PP I884-5, XIX, 499 .

${ }^{19}$ In the belief that 'anything that makes punishment more certain aids the prevention of crime', Hamilton recommended that these clauses become permanent laws: 'Memo. on the renewal of the Prevention of Crimes Act', I8 January I885: AP, Add MS 7733I.

${ }^{20}$ The Local Government Board, established in I872, assumed responsibilities for medical treatment and public hygiene formerly vested in the Poor Law Commissioners. 
Some days afterward he read for me at the Castle two memoranda which he had written for Lord Spencer - one on the subject of state advances \& the other on the subject of County Government. ${ }^{21}$

Gray returned from London some time in Dec. I spoke to him on the subject of the Crimes Act renewal ${ }^{22} \&$ the introduction of a County Government Bill. He quite agreed with my view that if the latter bill was introduced \& pushed on by the Government it would do more than anything else to quiet the country. I afterwards explained fully to Sir R. Hamilton Gray's view \& mine.

Some day early in the present month Sir R. Hamilton read for me a memorandum which he had written for Lord Spencer suggesting the best course to be followed by the Government in relation to Irish business in Parliament. ${ }^{23}$ This memorandum was very able \& manly. It strongly urged the introduction of a County Government Bill at once.

I told Sir R. H. that I intended to write a memorandum on the same subject \& that Charles Russell ${ }^{24}$ would give it to Mr. Gladstone. ${ }^{25}$ Sir R. H. approved of this course. I invited him to dine on Wednesday 7 Jany. to meet C. Russell \& Gray.

On 7 Jany Russell, Gray, Hamilton, R. Holmes \& Jonathan $\mathrm{Hogg}^{26}$ dined with me. A few days previously I wrote the promised memorandum $^{27} \&$ gave it to Hamilton to look over it. When he came to dinner he told me that he was delighted with the memorandum $\&$ that he was so struck with it that he had read it to Lord Spencer who also was really struck with it. Hamilton said, "It was just the complement of my memorandum as it dealt with the party aspect of the question which mine did not." I am in great hopes that the Government will introduce a County Government Bill for Ireland in the coming session.

\footnotetext{
${ }^{21}$ See 'State interference with industrial enterprise', i December I884 and 'Statement as to Local Government of Ireland', II February I885: CP/TNA, PRO 30/6/I27 (8), (II).

${ }^{22}$ The Prevention of Crime (Ireland) Act, I882 (45\& 46 Vict., c. 25 ) was due to expire and the Liberal ministry was considering its renewal.

${ }^{23}$ Hamilton argued that the concession of a measure of local government would remove a popular grievance and thus assist the operation of the Land Act: 'Memo. on the renewal of the Prevention of Crimes Act', I8 January I885: AP, Add MS 7733I.

${ }^{24}$ Charles Russell (I832-I90o), first Baron Russell of Killowen (I894), Lib. MP for Dundalk (r880-1885) and for South Hackney (I885-I894), KCB (I886), Attorney-General (I886, 1892-1894), Lord Chief Justice (1894).

${ }^{25}$ William Ewart Gladstone (1809-1898), Lib. MP for Midlothian (1880-1895), Prime Minister (I868-I874, I880-I885, I886, I892-I894).

${ }^{26}$ Jonathan Hogg (1847-1930), Chairman of William Hogg \& Company, treasurer of the Liberal Unionist Party and committee member of the Irish Loyal and Patriotic Union (1886), Governor of the Bank of Ireland (I90I-I902).
}

\section{${ }^{27}$ See Document 7.}


Afterwards Gray \& Hamilton had a long \& earnest conversation on politics for fully two hours.

Hamilton takes a deep interest in the cutting down of the Irish Bench to reasonable limits \& putting an end to the awful extravagance of the Irish legal establishment generally. He has told me several times that he reads over every now \& then my article on the Irish judicial establishment in the Fortnightly Review published in $1875^{28}$ \& that he thoroughly agrees with it.

I got Sexton last year to move for a return shewing the amount of civil business transacted before the Judges in Dublin \& on circuit. It discloses a state of things conclusively proving that the Irish Judges have scarcely any legal business to occupy them. ${ }^{29}$

The Bench is sure to be considerably reduced. On yesterday a meeting of the 'Benchers' was held. A letter from Lord Spencer was read asking for their opinion as to reducing the Irish circuits to 4 . This was strongly condemned. Baron Dowse ${ }^{30}$ moved that the Home Circuit might be abolished. This motion shewed an equal number of Benchers for \& against \& therefore the resolution was carried. This is satisfactory as it puts the Judges completely in the wrong. The Freeman attacks them strongly today. ${ }^{31}$ I find that Benjamin Whitney ${ }^{32} \&$ George Tyrell $^{33}$ two staunch Tory Solicitors are just as favourable as I am to cutting down the bench \& bar places \& emoluments to reasonable limits.

\section{I4 Jany. I885}

I went to the Under Secretary's Lodge today to see Sir R. Hamilton who was laid up with a cold. We had a talk about the Judges \& he told me that those Judges who had opposed the abolition of the Home Circuit, finding that there was a division of opinion among the Judges, had now come round to the theory that there ought to be only 4 circuits. We conversed about the reduction of legal charges in Ireland. He told me that he had reduced them from

\footnotetext{
${ }_{28}$ 'The Irish Judges', Fortnightly Review, 23 (March I875), pp. 408-421, and see his The Irish Fudges and Irish Chairmen (Dublin, 1876).

${ }^{29}$ See Return of Civil Cases in Ireland tried in Dublin and on Circuit, 1873-82: PP 1884, LXIII, 327 .

${ }^{30}$ Richard Dowse (I824-I89o), Lib. MP for Londonderry city (I868-I872), Baron of the Exchequer (1872-1890).

${ }^{31}$ See $F \mathcal{F}$, i3 January i885, p. 3.

${ }^{32}$ Sir Benjamin Whitney (I833-1916), Clerk of the Crown and Peace for Mayo, founder of Whitney \& Moore, solicitors (I882).

${ }^{33}$ George Gerald Tyrell, Clerk of the Crown and Peace for Armagh.
} 
over $\mathcal{E}_{\mathrm{I}}$ oo,ooo to $£ 79,000 .{ }^{34} \mathrm{He}$ also said he had very considerably reduced the constabulary estimate by stopping recruiting altogether for the present. The usual number of recruits per annum being 800 (eight hundred), he had reduced it to 30 for the past year - the annual wasting of the constabulary is about $800 .^{35}$

We spoke about the payment of Crown witnesses \& I recalled his attention to the witnesses' expenses in the trial of Fitzgerald, ${ }^{36}$ the supposed Fenian outrage monger in Dec. last, where I found that Mr. Peyton ${ }^{37}$ had recommended payment at a lower rate to Mr. O'Reilly ${ }^{3{ }^{3}}$ the Hotel Keeper, than to other witnesses in a similar rank of life. O'Reilly being the only Crown witness who gave evidence with hesitation for the Crown, that is, he was most guarded in saying that he could not conclusively identify the prisoner. Sir R. Hamilton said he feared my suspicions were too true \& that it apparently had been a habit with Crown Solicitors to pay witnesses "by results". He is most strongly opposed to any such detestable system \& he said he had issued instructions which would make it clear to Crown Solicitors that such a practice would not be tolerated by the Government. He has also put an end to the system of supporting Crown witnesses in a lavish fashion pending the trials at which they are to give evidence. $^{39}$

I mentioned to him that in relation to the change of venue clauses of the Crimes Act I believed that the Queen's Bench had, without any Crimes Act, full power to change venues in Criminal Cases. He said that if this was so it was most important \& I promised to look up the law \& let him know how it stood on the subject.

\footnotetext{
${ }^{34}$ Hamilton proposed to cut estimated expenditure on law charges and criminal prosecutions for $1885^{-1} 886$ from $£ 99,03$ I to $£ 79,206$ : Hamilton to Spencer, 5 and 23 December i884: AP, Add MS 7706o; Hamilton to Sir Henry Campbell-Bannerman, 29 January I885 and Hamilton to Sir Ralph Lingen, 3o January I885: CSO RP I885/I692 in RP $1885 / 2366$.

${ }_{35}$ Between 1883 and 1885 , the authorized force strength fell from I4,277 to I2,500: Treasury Blue Notes, 1894-I895: TNA, Ti65. For RIC expenditure, see CSO RPs I884/I5076, I884/II84I, I885/40II.

${ }^{36}$ Patrick Neville Fitzgerald (I85 I-I907), commercial traveller, representative for Munster on the Supreme Council of the IRB (I878), tried and acquitted of treason felony in November 1884: see Owen Magee, The IRB: the Irish Republican Brotherhood from the Land League to Sinn Fein (Dublin, 2005), pp. 127-I29.

${ }^{37}$ Randle Peyton (b. I820), crown solicitor for Leitrim, Sligo, and Roscommon (I874I885).

${ }^{38}$ Edward Albert O'Reilly, hotel proprietor in Wormwood-gate, Dublin. For his deposition, see Queen against Feremiah Lowry and Others: brief on behalf of the Crown: NLI, MS 5508 .

${ }^{39}$ Hamilton proposed that all crown witnesses should be paid at the minimum rate unless satisfactory reason was given for paying more: Hamilton to Spencer, 23 December 1884; circular to crown solicitors, I2 January I885: CSO RP I885/2366.
} 
I lent him A.M. Sullivan's ${ }^{40}$ memorandum for the Pope respecting the Parnell fund to read..$^{41}$ J.E. Kenny ${ }^{42}$ had lent this to me.

\section{I5 Jany. I885}

I sent to Hamilton a carefully prepared memorandum shewing the law \& practice in Ireland in relation to the power of the Queen's Bench Division to change the venue in Criminal Cases. ${ }^{43}$

\section{I6 Jany. I885}

I rode out to see Hamilton at the Under Secretary's Lodge. We discussed the above mentioned memoranda [sic] which he told me he had sent to his private secretary, without telling him from whom it came, in order that he might ask the Atty-Genl. why it was that the Government had set such store by the clause in the Crimes Act in relation to change of venue.

We discussed Dilke's ${ }^{44}$ \& Chamberlain's ${ }^{45}$ recent speeches. ${ }^{46}$ Hamilton's view is that these two statesmen have agreed between them that at the General election they will bid for the radical vote in England with a view of forming a radical Government of which Chamberlain would be Prime Minister. He believes that Gladstone will not continue in office as First Lord after the end of the coming session.

\section{I7 Jany. I885}

I met Thomas A. Dickson MP ${ }^{47}$ today. I asked him how the Liberal Party now stood in the north of Ireland. He replied that if there was to

\footnotetext{
$4^{\circ}$ Alexander Martin Sullivan (I829-I884), Home Rule MP for Co. Louth (I874-I880) and for Co. Meath (1880-I882), editor and proprietor of The Nation (1858-I877), author of influential accounts of Irish history.

${ }^{41}$ Sullivan penned several articles on the matter for The Nation in May 1883 and, in January 1884, published his Observations on the religious and political situation in Ireland for the information of church leaders: T.D. Sullivan, A.M. Sullivan: a memoir (Dublin, I885), pp. I53-I57.

${ }^{42}$ Joseph Edward Kenny (1845-1900), Nat. MP for Co. Cork South (1885-1892), surgeon to the North Dublin Union Hospital.

${ }^{43}$ And see his 'Memorandum showing the usual course of criminal proceedings in Ireland', 22 December i884: CSO RP 1885/2366.

${ }^{44}$ Sir Charles Wentworth Dilke (I843-19II), Lib. MP for Chelsea (I868-1886), President of the Local Government Board (I882-I885).

${ }^{45}$ Joseph Chamberlain (1836-I9I4), Lib. MP for Birmingham (I876-I885), Lib. U. MP for Birmingham West (I885-I9I4), President of the Board of Trade (I88o-I885), President of the Local Government Board (1886).

${ }^{46}$ Dilke spoke at Kensington on I3January: The Times, I4January I885, p. 6; Chamberlain appeared at Ipswich the following day: The Times, 15 January i885, p. 7.

${ }^{47}$ Thomas Alexander Dickson (I833-I909), Lib. MP for Co. Tyrone (I88I-I885), Lib. U. MP for St Stephens Green Division, Dublin (1888-I892).
} 
be any attempt to renew the Crimes Act the Liberal party in Ireland would be annihilated \& that, for his part, if any such attempt were made he would denounce it.

23 Jany. 1885

I wrote to Dickson a few days ago suggesting that he would write to Lord Spencer or Sir R. Hamilton expressing the opinions which he had expressed to me in the above conversation. He replied that he had done so already.

I received from Charles Russell two letters of which I kept copies \& then returned them. One was from Sir Charles Dilke to whom Russell had sent a copy of my memorandum on County Government. Dilke's letter was simply, "But I should regard it as a great calamity that a County Govt. Bill for Ireland should be introduced before County Govt. for England". The other letter was from Herbert Gladstone who says that he had given the memorandum to his father who had read it in the train on his way from Hawarden to London \& that he was greatly struck with its clearness \& force \& that he had sent it to Lord Spencer for his opinion..$^{8}$

I showed these letters on yesterday to Sir R. Hamilton.

30 Jany. I885

Russell has sent me Chamberlain's letter to him on the same subject. Chamberlain's letter encloses a copy of a letter which he wrote to Mr. Dingnan $^{49}[$ sic] of Walsall on I7 Dec. 84 in which Chamberlain pronounces in favour of an extension of local government to Ireland which would include among the matters to be exclusively dealt with by an Irish Assembly all questions of education \& land law..$^{50}$

I not only shewed this letter to Sir R. Hamilton but I gave him a copy of it.

Feby. 1885

I met T.A. Dickson MP at the levee..$^{{ }^{1}}$ He promised to call on me to discuss fully as to the danger \&c. of renewing the Crimes Act. He

${ }^{4}$ See Document 7. Gladstone returned to London early on 20 January I885: GD, XI, p. 279 .

${ }^{49}$ William Henry Duignan (1824-I9I4), Director of the Walsall Wood Colliery Company, Mayor of Walsall (I868-1869). An antiquarian and etymologist, he travelled widely within the United Kingdom: C.D.H. Howard, "The man on a tricycle": W.H. Duignan and Ireland, I88I-5', IHS, I4, no. 55 (March I965), pp. 246-26o.

${ }^{5}$ Chamberlain to Duignan, i7 December i884:JCP, JC8/3/I/24.

${ }^{5^{1}}$ The first levee of the season was held on 3 February 1885: The Times, 3 February 1885 , p. 6. 
called \& showed me a proof copy of a lecture proposed to be delivered by him in Liverpool in a few days but he said that owing to the dynamite explosion in the Houses of Parliament it would be impossible to address any English meeting on Irish affairs. ${ }^{5^{2}}$ The proposed lecture is admirable in tone. It goes dead against any renewal of the Crimes Act \& urges the immediate granting of County Boards. I was so struck by the manly tone of the lecture that I told him all I had done \& read for him the memoranda \& letters. He was very much pleased \& said that now that he found I had paved the way, by expressing so strongly to the Executive the importance of relying on an extension of freedom instead of resorting to coercion, he would work still harder to inculcate the same advice. I advised Dickson to publish his lecture as a pamphlet. ${ }^{53}$

I3 Feby.

I received a letter from Dickson stating that he had strongly urged his views again but he feared without avail as "Redmond's speeches were quoted as an evidence of the necessity for renewing the Crimes Act". ${ }^{54}$

I7 Feby.

I met T. Harrington $\mathrm{MP}^{55}$ he said he wished to warn me that I was much blamed because I had undertaken the task of bringing about an understanding between Sir R. Hamilton \& Dr. Walsh ${ }^{56}$ of Maynooth, who has just been appointed Vicar Capitular on the death of Cardinal McCabe which took place a few days ago. ${ }^{57}$ I replied that if the accusation against me was that Hamilton \& Dr. Walsh dined at my table together some months ago I plead guilty but I must reserve to myself the right of inviting to my private table any guest I please.

\footnotetext{
${ }^{52}$ The explosion occurred on 24 January 1885: K.R.M. Short, The Dynamite War: IrishAmerican bombers in Victorian Britain (Dublin, 1979), pp. 205-208.

${ }^{53}$ See Thomas A. Dickson, Committee on Irish Affairs, Paper No. 4: an Irish policy for a Liberal Government (London, I885).

${ }^{54}$ William Hoey Kearney Redmond (I86I-I9I7), Nat. MP for Wexford (I883-I885), for Fermanagh North (1885-1892), and for Clare East (I892-I917). During demonstrations at Carndonagh, Co. Donegal and Newtonbarry, Co. Wexford, Redmond had advocated the boycotting of tenants occupying evicted farms: The Times, 2 February I885, p. 6; 3 February I885, pp. 6, 9 .

55 Timothy Charles Harrington (I85 I-I9Io), Nat. MP for Co. Westmeath (I883-1885) and for Harbour Division, Dublin (1885-1910), Secretary of the Irish National League (I882-I89I), proprietor of the Kerry Sentinel.

${ }^{56}$ William Joseph Walsh (I84I-I92I), professor of moral theology and President (I8801885) of St Patrick's College, Maynooth, Archbishop of Dublin (I885-I92I).

${ }^{57}$ Edward MacCabe (1816-1885), Archbishop of Dublin (I879-1885). He died suddenly on in February.
} 
24 Feby.

It is announced in today's papers that the Prince and Princess of Wales will visit Ireland early in April \& will hold a levee \& drawing-room $\&$ that in anticipation of their so doing the Lord Lieutenant's levee advertised for early in March is abandoned..$^{8}$

There is much speculation as to the meaning of this move. In Parliament last night Gladstone in reply to Lewis ${ }^{59}$ of Londonderry point blank refused to say whether the Crimes Act would be renewed. ${ }^{60}$ My impression is that it will not.

28 Feby.

The division took place last night on the motion for a vote of censure on the ministry in relation to their Egyptian policy \& conduct. The division showed a majority of only $\mathrm{I}_{4}$ for the ministers. The Irish party numbered $42 \&$ voted solid against the ministers. ${ }^{61}$

I saw Sir Robt. Hamilton this morning \& I urged him very strongly to do everything he could to induce the ministry at once to announce the proposed introduction of a County Government Bill for Ireland. He thoroughly agreed with me that it would be wise to introduce a bill for this purpose without delay \& agreed also that the very fact of the Irish party having voted against the ministry would enable the ministry to escape odium in England in the event of introducing such a bill, by showing that its introduction was not the result of any bargain or 'treaty'.

$2^{\text {nd }}$ March

Robert W. Holmes, Brougham Leech, ${ }^{62}$ Mr. Williams, Solicitor of Wakefield $^{63} \&$ myself today held our first meeting as Commissioners to enquire into the working of the Registry of Deeds Office. ${ }^{64}$

\footnotetext{
$5^{8}$ See The Times, 24 February 1885 , p. 10.

${ }^{59}$ Sir Charles Edward Lewis (I825-1893), Con. MP for Londonderry city (I872-I886) and for Antrim North (I887-I892).

${ }^{60}$ Gladstone declined to discuss the legislation until after the Redistribution Bill was passed: Hansard, CCXIV, cols I047-1048.

${ }^{61}$ See The Times, 2 March I885, p. 8. On 23 February, John Morley had tabled a motion opposing the ministry's plan to send troops to Khartoum: Hansard, CCXIV, col. IO7I.

${ }^{62}$ Henry Brougham Leech (I843-I92I), professor of international law and jurisprudence at Dublin University (1878-I888). A pronounced unionist, he wrote 'Is Ireland overtaxed?' in reply to Robert Giffen's home rule proposals (Journal, 7 January 1886): The Times, II May i886, p. I6; 26 March i92I, p. II.

${ }^{63}$ William L. Williams, solicitor to the justices of the West Riding, Yorkshire, registrar to the West Riding Registry, Wakefield.

${ }^{6}$ The commission was established by the Treasury in December I884 to recommend improvements: see Registry of Deeds Office (Dublin): PP I887, LXVII, 43 I.
} 
Io March

On today the voting of the Parish Priests \& Chapter of Dublin for the selection of an archbishop took place. ${ }^{6_{5}}$ The result was as follows,

$\begin{array}{lr}\text { Dr. Walsh - } & 46 \\ \text { Dr. Donnelly }^{66}- & \text { I2 } \\ \text { Dr. Tynan }^{68}- & 3 \\ \text { Dr. Woodlock }^{69}- & \frac{2}{63}\end{array}$

Only one absentee Dr. Verdon ${ }^{67}$ who is in Rome.

I received a letter from C. Russell asking could I suggest any medium course as to the renewal of the Crimes Act. I wrote in reply strongly urging him to use his influence with the ministry to dissuade them from asking for its renewal at all.

\section{I March}

Sir R. Hamilton returned this morning from Gibraltar after an absence of nearly a month on a trip for his health. I saw him for a few minutes \& remarked to him that the absence of crime in the country was almost complete \& that I hoped we had therefore heard the last of attempts to renew the Crimes Act. He said that when he saw the newspapers at Portsmouth he was struck by observing news of disturbances and upheavals in almost every part of the British Dominions except Ireland. He says he has not read a line or heard a word spoken about Ireland for a month.

\section{$\mathrm{I}^{\text {st }}$ May}

In London staying at the National Liberal Club. I came over at the instance of the Council of the Irish Law Society to smooth the passage through the House of Commons of the bill introduced by Lord Fitzgerald ${ }^{70}$ in the House of Lords to amend the law relating to the status \&c. of solicitors in Ireland..$^{71}$

\footnotetext{
${ }^{6}$ See The Times, I I March i885, p. Io.

${ }^{66}$ James Donnelly (I823-I893), Bishop of Clogher (I864-I893).

${ }_{77}$ Michael Verdon (I838-I9I8), Vice-rector of the Irish College in Rome, Bishop of Dunedin (I896).

${ }^{68}$ Patrick J. Tynan, private secretary to Cardinals Paul Cullen and Edward McCabe.

${ }^{69}$ Bartholomew Woodlock (I8I9-I902), President of All Hallows College, Rector of the Catholic University, Dublin, Bishop of Ardagh and Clonmacnois (I879-1895).

${ }^{70}$ John David Fitzgerald (I815-I889), first Baron Fitzgerald (I882), Lib. MP for Ennis (I852-I860), justice of Queen's Bench, Ireland (I860-I882), Lord of Appeal (I882-I889).

$7^{1}$ Bill to amend Laws for Regulation of Profession of Solicitors in Ireland: PP I884-5, V, 473 .
} 
I saw John Morley, ${ }^{72}$ MP for Newcastle, at the House \& had a long talk with him. He asked me as to the condition of Ireland regarding crime \& I told him that the country was practically free of crime \& that unless there should happen to be a very bad harvest this year immunity from crime would probably continue. He told me that the question of renewal of the Crimes Act was at present under the consideration of the Cabinet \& that the only member of the Cabinet really urgent in favour of renewal was Lord Spencer, but that as he insists upon the renewal he is backed up by Lord Hartington ${ }^{73} \&$ others. He believes that if non-renewal be decided upon Lord Spencer would resign \& that Trevelyan ${ }^{74}$ considers himself bound in honour to unite his fortunes with Lord Spencer's on this question, so that Spencer's resignation would also mean Trevelyan's secession \& the united effect would probably be to burst up the Cabinet. Morley will steadily and determinedly oppose the renewal. He asked me what provision in the Crimes Act did I regard as most important. I told him that Sir R. Hamilton considered the most necessary to be - change of venue special juries \& tribunal of 2 resident magistrates for summary trial of boycotting \& such like offences. Morley says that Jenkinson ${ }^{75}$ told him the most important provision was - secret inquiries - \& charging compensation for injuries on the incriminated localities. ${ }^{76}$ He says also that Dilke \& Chamberlain will not consent to renewal of the Crimes Act unless a compensation be made by introducing some important reform of Ireland at the same time. I suggested that if this was so the radicals ought to press for the introduction of a bill for County Boards in Ireland this session. Morley suggests the immediate establishment in Ireland of a representative board of say 50 members for all Ireland with Parnell ${ }^{77}$ at their head, leaving to this board the settlement of land questions \& the distribution of all money constituted by Ireland towards education. He promises to come to Ireland at Whitsuntide.

${ }^{72}$ John Morley (1838-1923), first Viscount Morley of Blackburn (1908), Lib. MP for Newcastle upon Tyne (I883-I895), Chief Secretary for Ireland (I886, I892-I895).

${ }^{73}$ Spencer Compton Cavendish (I833-1908), Marquess of Hartington (1858) and eighth Duke of Devonshire (I89I), Lib. MP for North-East Lancashire (I880-I885) and for Rossendale (I885-I89I), Chief Secretary for Ireland (I870-1874), Secretary of State for War (1882-I885).

${ }^{74}$ George Otto Trevelyan (I838-I928), second Baronet (I886), Lib. MP for Hawick Burghs (I868-1886) and for Glasgow Bridgeton (1887-I897), Chief Secretary for Ireland (I882I884), Chancellor of the Duchy of Lancaster (I884-1885), Secretary of State for Scotland (1886, I892-I894).

${ }^{75}$ See appendix.

${ }^{76}$ For the clauses of the Prevention of Crime (Ireland) Act, I882, see Virginia Crossman, Politics, Law and Order in Nineteenth-Century Ireland (Dublin, 1996), pp. 224-226.

${ }_{77}$ Charles Stewart Parnell (I846-I89I), Nat. MP for Co. Meath (I875-1880) and for Cork city (I880-1890), President of the Irish National Land League (I879-I88I) and of the Irish National League (I882-I89o), Chairman of the Home Rule Party (I880-I890). 
$2^{\text {nd }}$ May

I called at the Thatched House Club ${ }^{78}$ to see if Escott, ${ }^{79}$ the Editor of the Fortnightly Review was there. He was \& he asked me to call on him tomorrow as he was very anxious to talk over some matters with me.

$3^{\text {rd }}$ May

I called on Escott. He wanted to get all the information he could about the Crimes Act. I explained its main provisions to him \& told him the clauses which Sir R. Hamilton attached most importance to. He then told me that the Cabinet was at open war about the question of renewal or non-renewal \& that a minister had as much as told him that it was about an even chance that the Cabinet would break up on the question. Escott's view is that Lord Spencer is the only member urgently anxious for renewal but that he is dogged on the point \& that if he brings Lord Hartington \& the Whig section of the Cabinet with him the result will be that Lord Spencer will wreck the Government \& that Gladstone, Chamberlain \& Dilke will retire from the Cabinet. If Gladstone retires Escott thinks he, Gladstone, will never again join in public life but if, on the other hand, Gladstone can retain power he believes that he will not abandon public life while he lives. He says that Dr. Andrew Clark ${ }^{80}$ has practically told Gladstone's family that if the Prime Minister retires from public life he will probably die in a few months.

I find that Escott hates Wilson ${ }^{81}$ of the Times. He says he is an ill-conditioned dyspeptic canting fellow.

\section{May}

I saw Sir Robert Hamilton today \& told him what Morley \& Escott had mentioned to me. He said that he was not altogether surprised at what I mentioned although he had not heard any details. He repeated that the only provisions in the Crimes Act he laid much stress by are those for change of venue - special juries \& making intimidation a crime. These he considers absolutely necessary. The change of venue

\footnotetext{
${ }^{78}$ The Royal Navy Club of I785, which met at the Thatched House Tavern in St James Street, before relocating to Willis's Rooms in 1862 .

79 Thomas Hay Sweet Escott (I844-I924), journalist and editor of the Fortnightly Review (I882-I886).

${ }^{80}$ Sir Andrew Clark (I826-I893), Physician to the London Hospital (I853-I886), President of the Royal College of Physicians (I888-I893), personal physician to W.E. Gladstone (I866I893).

${ }^{81}$ Edward Daniel Joseph Wilson (1844-I9I3), contributor to and leader writer for The Times (1870-1903). His opposition to the Land League and home rule was described as 'the great work of his life': The Times, 3o June igi3, p. II.
} 
provision he would extend to England, \& he says that the intimidation provisions are virtually in force already in Scotland.

He added that what he would wish to see done this year is the enactment of

(a) a measure renewing the provisions above stated.

(b) a measure establishing County Government.

(c) a measure abolishing the Viceroyalty.

$\mathrm{He}$ is in hopes that the very acuteness of the crisis in the Cabinet respecting (a) may enable (b) \& (c) to be brought forward \& carried this session. ${ }^{82}$

He was very anxious to obtain from me an explanation of the absence of all the Irish Bishops from the Prince of Wales's levee. ${ }^{8_{3}} \mathrm{My}$ explanation is that the Bishops are no longer leaders but followers \& that in absenting themselves they simply yielded to the popular wish to show disapprobation of Lord Spencer's regime.

\section{I4 May}

I saw Sir R. H. at the Castle today \& spoke about the Crimes Act \& County Government. He did not state what course the ministry would pursue, in fact he said that he did not yet know what decision had been arrived at, but he plainly expected that a County Government Bill would be introduced \& pressed this session.

We spoke about the prospects of Dr. Walsh being appointed Archbishop of Dublin \& he agreed with me that it would be a misfortune if he were not appointed. "What we want" said he "in public positions in Ireland is men who approach their duties with sympathy for the people - Such men command influence with the people \& the sense of responsibility developed by their position sobers them even if at first they may be extreme in their views".

\section{I6 May}

The papers of this morning contain Gladstone's statement made last night as to the intentions of the Government. The statement is very disappointing - no County Government Bill, no Purchase Bill, nothing but some "valuable \& equitable" provisions of the Crimes Act, to use Mr. Gladstone's words. ${ }^{84}$

The Ministers are certainly though I suppose unwittingly playing into Parnell's hands. He will now be able to lash the constituencies in Ireland into a rage on the very eve of the General election.

\footnotetext{
${ }^{82}$ See Document 9.

$8_{3}$ The levee took place on 9 April i885: The Times, io April i885, p. Io.

${ }^{8}$ See Hansard, CCXCVIII, cols 626-63I.
} 
I8 May

The newspapers this morning announce the new Irish Law Appointments: ${ }^{85}$ John Naish Chancellor, Samuel Walker ${ }^{86}$ Attorney General \& The MacDermot ${ }^{87}$ Solicitor General.

I saw Sir R. H. today. He said that he never suffered more blank disappointment than in reading Gladstone's speech announcing Crimes Act renewal \& no reforms for this session. He also said that when history comes to be written men will see how different a part Lord Spencer has played from that which is popularly attributed to him.

\section{I May}

Mr. Gladstone on yesterday mended his hand by stating that the ministry had on consideration resolved to introduce a Land Purchase Bill and a Labourers Act Amendment Bill for Ireland. ${ }^{83}$

\section{May}

This is Whitsunday. Sir R. Hamilton, R. Adams $^{89}$ \& L. Waldron ${ }^{90}$ came out to me to Ballybrack to have a ramble about the hills. Sir R. spoke to me about the renewal of the Crimes Act \& I again strongly opposed the clauses giving to the Attorney General power to change venues \& require special juries. After we had walked to the top of the scalp we all sat down for a rest and the conversation happened to turn upon Parnell. Some one asked what was the motive power in Parnell. Adams replied that he believed Parnell's strongest passion was hatred of England. Sir R. H. asked why should Parnell hate England, was he not educated in Cambridge? Adams replied that he believed Parnell had stated that while at Cambridge \& up to the date of the execution of the 'Manchester Martyrs ${ }^{\text {'91 }}$ he had not devoted a

${ }^{85}$ The appointments became necessary upon the sudden death of Sir Edward Sullivan, the Lord Chancellor of Ireland: The Times, I8 May I885, p. Iо.

${ }^{86}$ Samuel Walker (I832-I9II), Lib. MP for Londonderry (I884-I885), Solicitor- and Attorney-General for Ireland (1883-1885, I885, I886), Lord Chancellor for Ireland (I892I895, I905-I9II).

${ }_{87}^{87}$ Hugh Hyacinth MacDermot (1834-1904), Solicitor- and Attorney-General for Ireland (I885, I886, I892-I895).

${ }^{88}$ See Hansard, CCXCVIII, cols $97 \mathrm{I}-972$.

${ }^{89}$ Richard Adams (1846-I908), journalist for the Cork Examiner and the Freeman's fournal (I868-I873), barrister on the Munster circuit (I873-I894), county court judge for Limerick (1894).

${ }_{90}^{\circ}$ Laurence Ambrose Waldron (1858-1923), Chairman of the Dublin and Kingston Railway and Dublin United Tramways (1896), commissioner of National Education, son of Laurence Waldron MP (I8II-I875).

${ }^{91}$ William Allen, Michael O'Brien, and Michael Larkin were executed on 23 November I867 for the murder of a police sergeant during an attempt to rescue the Fenian leader Thomas Kelly from custody in Manchester. 
thought to Irish politics, but that he was driven wild with rage at that event \& began then to study Irish political questions with eagerness and as a result he has acquired a downright hatred of England. Sir Robert then amazed us by asking who were the Manchester Martyrs \& why did their execution excite anger in Ireland. Adams explained the particulars of the offence \& of the trial of Allen, Larkin \& O'Brien \& the facts seemed quite new to Sir Robert. I could not resist the temptation of pointing out to him that his want of acquaintance with the details or even with the outlines of an event which had thrilled the Irish Race all over the world was a very strong argument in favour of Home Rule for Ireland, for if he, an able and keen man always alive to public events passing around him, knew so little about an event which every Irishman was fully acquainted with \& which had caused fierce controversy for years in Ireland it was reasonable to assume that the majority of Englishmen were still less acquainted with Irish affairs. This observation evidently went home. Sir Robert was silent for many minutes \& he plainly felt the force of what I had said.

In the evening, Sir R. H., Adams, Waldron, Richd. O'Shaughnessy, ${ }^{92}$ late MP for Limerick, \& G.V. Hart, ${ }^{93}$ Revising Barrister for Dublin, dined with me.

\section{May}

I dined this evening with E. Dwyer Gray MP, the company included Dr. Walsh, Vicar Capitular, Sir Charles Dilke MP, Lyulph Stanley MP ${ }^{94}$ Lord Brownlow, ${ }^{95}$ the Bishop of Bedford ${ }^{96}$ Chief Justice Morris, ${ }^{97}$

${ }^{92}$ Richard O'Shaughnessy (b. I842), Home Rule MP for Limerick city (I874-I883), twice considered for the post of Under-Secretary for Ireland: Trevelyan to Spencer, I7 May I882; Spencer to Trevelyan, 4 March I883: AP, Add MSS 76944, 76952.

${ }_{93}$ George Vaughan Hart (I84I-I9I3), Revising Assessor for Dublin (I88I-I89I), Regius Professor of Feudal and English Law, Trinity College (I890-1909).

${ }^{94}$ Edward Lyulph Stanley (I839-I929), fourth Baron Sheffield (I909), Lib. MP for Oldham (1880-I885).

${ }_{95}$ Adelbert Wellington Brownlow Cust (I844-I92I), third Earl Brownlow (I867), Con. MP for Shropshire North (I866-I867), Parliamentary Secretary to the Local Government Board (1885-1886), Paymaster-General (1887-1889).

${ }^{96}$ The Revd William Walsham How (1823-1897), Bishop-suffragan of Bedford (I879I888), Bishop of Wakefield (I888-1897). Brownlow and How were members of the Royal Commission on the Housing of the Working Classes, which was then sitting in Dublin: The Times, 27 May I885, p. 6.

${ }^{97}$ Michael Morris (1827-1904), first Baron Killanin (1900), Lib. MP for Galway (18651867), justice of Common Pleas (1867-1887), Lord Chief Justice of Ireland (I887-1889), an opponent of home rule but a critic of the shortcomings of Irish government. 
Jesse Collings MP, ${ }^{98}$ Thos Dickson MP, Alderman Meagher MP, ${ }^{99}$ the Lord Chancellor \& others. ${ }^{100}$

I sat beside Jesse Collings. He told me that he \& Chamberlain live together in London. He believes that Chamberlain is more likely than Dilke to become Prime Minister \& he thinks that Dilke shares this view. He says that Dilke \& Chamberlain are thoroughly loyal to each other. But for the fact that the complication about Russia was not quite at an end he believes that both Dilke \& Chamberlain would have left the Cabinet before the $\mathrm{I} 5^{\text {th }}$ May. They are determinedly hostile to any renewal of the Coercive Act \& nothing but the fear of being thought cowardly for deserting the Cabinet in the midst of their foreign troubles would have induced them to remain members of a Cabinet pledged to renew any portion of the Crimes Act. He says that both Chamberlain \& Dilke are in favour of a scheme which would virtually be Home Rule \& are in favour of granting it at once. They would have not only County Boards but also a Central Assembly or Council in Dublin, elected not appointed \& endowed with legislative powers in relation to all matters affecting Ireland alone. He is MP for Ipswich, a constituency in which there is not a single Irishman, \& yet he says that owing to his persistently supporting the Irish party \& boldly expressing in Parliament \& to his constituents his belief in liberty as the only panacea for Ireland his constituents are practically united in condemning coercion \& advocating extension of free institutions to Ireland.

After dinner, when we had gone up to the dining room, I took Dickson to one side to learn from him the explanation of the election in Antrim last week at which Sinclair ${ }^{101}$ the Liberal Candidate succeeded in beating Lord O'Neill, ${ }^{102}$ the Tory Candidate, by I 39 votes ${ }^{103}$ Dickson explains the election as a protest against coercion.

He says that he, Dickson, put prominently before the Presbyterian voters the iniquity \& folly of renewing any portion of the Crimes Act \& that his sentiments on this point were enthusiastically cheered. Sinclair pledged himself to oppose coercion in every form. While we were speaking Sir Charles Dilke came over, sat down beside me $\&$ entered into an animated discussion in reference to the Crimes

\footnotetext{
${ }^{98}$ Jesse Collings (I83 I-I920), Lib. MP for Ipswich (I880-I886), Parliamentary Secretary to the Local Government Board (I886).

${ }^{99}$ William Meagher, Lord Mayor of Dublin (1884), Nat. MP for Co. Meath (1884-1885).

${ }^{100}$ For Dilke's account of the evening, see his diary, 26 May I885 (copy): JCP, JC8/2/I.

${ }^{101}$ William Pirrie Sinclair (1837-I90o), Lib. MP for Co. Antrim (I885) and for Falkirk district (I886-I892), favoured reform of Irish government but opposed home rule.

${ }^{102}$ Edward O'Neill (1839-1928), second Baron O'Neill (I883), Con. MP for Co. Antrim (1863-1880), owner of 66,00o acres at Shanes Castle, Co. Antrim.

${ }^{103}$ The election took place on 2r May I885; Sinclair polled 397I votes and O'Neill 3832.
} 
Act. I openly told him that in my opinion Lord Spencer was wrong in asking to have those provisions of the Act renewed which would give the Attorney General of the day the power of changing venues \& obtaining special juries merely by his own fiat. He asked why I held this opinion \& I replied because under the Common Law the Judges have the power of changing the venue when it is proven to them that a fair trial cannot be had in the venue where the crime was committed. This seemed new to Sir Charles \& [he] was much struck with it \& wrote it down. I told him that I had prepared some time ago a memorandum giving full particulars as to the state of the law in relation to change of venues ${ }^{104} \&$ he asked me to let him have a copy of it \& also if I could to let him have a memorandum expressing generally my views on the Crimes Act. I promised to send these to him.

We had an interesting chat about the authorship of the letters of Junius. ${ }^{105}$ Sir C. Dilke's grandfather ${ }^{106}$ was perhaps the best informed man in England on this question. He was quite satisfied that the letters were not written by Sir Philip Francis ${ }^{107}$ or by Lord George Sackville. ${ }^{108}$ He never formally accepted the claims of any one man to be the author but he considered that in all probability the author was either Dr. Mason ${ }^{109}$ Chaplain to the King, or John Wilkes. ${ }^{\text {I10 }}$ Sir Charles Dilke said that his grandfather regarded Macaulay ${ }^{\mathrm{II}}$ as a slap dash writer who did not use sufficient diligence in investigation before writing.

\section{${ }^{104}$ See Journal (15 January $\mathbf{1 8 8} 5$ ).}

${ }^{105}$ Junius was the pseudonym of the writer who contributed a series of brilliant polemical letters to the Public Advertiser between $\mathrm{I} 76 \mathrm{~g}$ and $\mathrm{I} 772$, fiercely criticizing the ministries of the Duke of Grafton and Lord North: Francesco Cordasco, Funius and His Works: a history of the letters of Junius and the authorship controversy (Hillsdale, NJ, I986).

${ }^{106}$ Charles Wentworth Dilke (I789-I864), editor of the London Magazine (I824) and the Athenaeum (I830), author of several influential articles on the subject of Junius.

${ }^{107}$ Sir Philip Francis (I740-I8I8), amanuensis to William Pitt (I76I-I762), councillor of the Governor-General of Bengal (I774-1780), MP for the Isle of Wight ( $\left.1784^{-1} 790\right)$, for Bletchingly (1790-1798), and for Appleby (1802-1807), first identified as Junius by John Taylor in I816, a view supported by modern statistico-linguistic analysis: Alvar Ellegard, Who was funius? (Stockholm, 1962).

${ }^{108}$ George Sackville Germain (I716-I785), first Viscount Sackville (I782), British general but dismissed from the service for neglect of duty at the battle of Minden (I759), MP for Dover (I74I-I746), for Hythe (I76I-I768), and for East Grinstead (I768-1782), Chief Secretary for Ireland ( $175^{\mathrm{I}-\mathrm{I} 756)}$, Colonial Secretary ( $\left.1775^{-1782}\right)$, adopted the name Germain in 1770.

${ }^{109}$ William Mason (1725-1797), King's chaplain (I757), canon of York (I762), prominent in agitation for parliamentary reform (1780), literary executor for Thomas Gray; see his The Poems of Mr. Gray, to which are prefixed memoirs of his life and writings (York, I775).

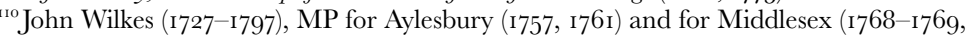
I774-I790), co-founded the North Briton, arrested for libelling George III ( $\left.{ }^{7} 763\right)$ and expelled from the House of Commons in I769, when his case was taken up by Junius.

${ }^{I I I}$ Thomas Babington Macaulay (I800-I859), first Baron Macaulay (I857), Lib. MP for Calne (1830-I832), for Leeds (I832-I834), and for Edinburgh (I840-I847, I852-I856), 
27 May

John Morley MP for Newcastle called on me today. I told him of the conversation which I had last evening with Dilke \& he was much pleased at Dilke asking for the memorandum from me. He mentioned that after he (Morley) had seen me in London he met Dilke \& told him my views, adding that "Fottrell is a man whose scent of Irish difficulties I have now for some years found to be rarely at fault".

Morley told me what he knew about the late Cabinet struggles on the subject of the Crimes Act \& from what he told me, joined to what I had already heard from Jesse Collings, I think that events occurred somewhat in this way -

Lord Spencer demanded a renewal of such portions of the Crimes Act as would give -

I. Change of venue

2. Special jury on the fiat of the Attorney General

3. Summary jurisdiction in cases of boycotting and intimidation 4. Secret enquiry.

Chamberlain, Dilke \& Gladstone strongly opposed any renewal but after a big fight they gave in, whereupon Lord Spencer said "I am not going back to Ireland with a rod in pickle \& nothing else". When asked what else he wanted, he said a County Government Bill for Ireland. Chamberlain \& Dilke promptly agreed but they said in effect "understand that what we mean is a bill which will not alone establish Boards in each County for the business of such County exclusively but which will also establish a central elective assembly in Dublin with legislative powers for exclusively Irish affairs." This proposition struck Lord Spencer as too rapid \& sweeping \& thereupon it was resolved that no bill dealing with Local Government should be introduced this session. It was also agreed that no Land Purchase Bill should be introduced.

So matters remained until the 20 May when Gladstone, dreading the effect of Dickson's crusade against the Government on account of the policy of coercion \& no remedial legislation, suddenly announced in Parliament without consulting Dilke or Chamberlain that the Government would introduce a Land Purchase Bill. This was regarded by Chamberlain \& Dilke as a cancellation of the entire Cabinet agreement \& accordingly they are now pressing again to have coercion abandoned in toto. 
28 May

I read for Morley portions of the memorandum which I am preparing for Dilke \& he highly approved of them. He told me that but for the Russian complication ${ }^{112} \&$ the certainty that Lord Salisbury's ${ }^{113}$ advent to power would mean a Russian War, not only Chamberlain and Dilke but even Gladstone himself would have resigned sooner than sanction a renewal of any part of the Crimes Act.

He tells me that since Trevelyan has left Ireland his views have been much modified, so much so that when at the Cabinet Council he urged objection on principle to a renewal of any part of the Crimes Act, Lord Spencer blurted out, "It is strange that when you were my Chief Secretary you never expressed these lofty sentiments."

I took Morley up to the Castle to lunch with Sir R. Hamilton. No one was present save the three of us. After lunch we discussed with our cigars the question of renewal of the Crimes Act. Sir Robert advocated the renewal of the provisions for change of venue, special jury \& summary jurisdiction for boycotting. Morley \& I took the opposite side. In the course of the discussion Sir Robert astounded me by saying that the Conspiracy Act of $1875^{114}$ did not apply to Ireland. I replied that within the last few days I had occasion to look into the Act \& that I was quite clear it did apply to Ireland. Sir Robert said that the burden of the advice given to him \& Lord Spencer by the legal adviser of the Castle ${ }^{\mathrm{I1}}$ was to the effect that the Act did not apply.

Morley expressed his profound astonishment at this statement and mentioned that he had met at Edward Gibson's MP ${ }^{16}$ last evening

\footnotetext{
${ }^{112}$ A skirmish at the Afghan-Russian border on 30 March had threatened to bring Britain and Russia into armed conflict: see R. A. Johnson, 'The Penjdeh incident, I885', Archives: The Journal of the British Records Association, 24, no. Ioo (April I999), pp. 28-48.

${ }^{113}$ Robert Arthur Talbot Gascoyne Cecil (1830-1903), third Marquess of Salisbury (I868), Con. MP for Stamford (I853-I868), Foreign Secretary (I878-I880, I885-I886, I886-I892, I895-I900), Prime Minister (I885-I886, I886-I892, I895-1902).

${ }^{114}$ The Conspiracy and Protection of Property Act, I875 (38 \& 39 Vict., c. 86) was designed to regulate picketing during trade disputes. Section seven made it an offence, punishable by up to three months' imprisonment, to compel another person to abstain from doing any act that they had a legal right to do by violence or intimidation: A.E. Musson, British Trade Unions I800-I875 (London, I972), pp. 62-63; RIC Inspector-General's circular, 3I January I88г: TNA, HO г84/гi6.

${ }^{115}$ The Law Adviser counselled the Irish executive and magistracy on points of law. The post was abolished in 1883 .

${ }^{116}$ Edward Gibson (I837-1913), first Baron Ashbourne (1885), Con. MP for Dublin University (1875-1885), Attorney-General (1877-1880) and Lord Chancellor of Ireland (1885-1886, I886-I892, I895-1905).
} 
at dinner the Master of the Rolls, ${ }^{117}$ and that he (the Master) has told him not only that the Act did apply to Ireland but that in his opinion it would enable the Executive to deal with all questions such as intimidation or boycotting which might arise in Ireland.

Sir Robert's objection as to the change of venue has something in it. He says he was advised that under the ordinary law a change of venue could not be moved for until after a bill had been found against the accused by the Grand Jury of the venue in which the crime was committed \& that therefore a change of venue would always involve a delay of the trial. There is something in this but not much. The delay would be more prejudicial to the prisoner than to the Crown. Morley rather 'stumped' Sir Robert by quoting the evidence of Lord (then Mr. Justice) Fitzgerald before the Lords Committee on Irish Jury Law ${ }^{\text {I18 }}$ (in I88I I think) in which that Judge strongly expressed his dissent from the proposal to give to the Attorney General the power by his simple fiat of changing venues. Hamilton thinks that at the General election the Liberals will have an overwhelming majority in England \& Scotland.

\section{May}

Having completed my memorandum as to the Crimes $\operatorname{Act}^{119}$ I forwarded it today to Sir Charles Dilke in the Reform Club whither he always, as I learn from Morley, gets his private letters addressed so that they may not be opened by his secretary.

\section{3o May}

I saw Morley today at the Shelbourne Hotel ${ }^{120}$ and told him I had forwarded the memorandum to Dilke but that I had been turning over in my mind whether it would not be improper for me, an Irish Crown official, to give a copy to him who had a motion down in his name in opposition to the ministry. ${ }^{121}$ He pondered for a moment \& then said "you are quite right \& I shall not take a copy. We Liberals in England shall have occasion during the next Io or I5 years to make

\footnotetext{
${ }^{117}$ Andrew Marshall Porter (I837-I919), Lib. MP for Co. Londonderry (I88I-I883), Solicitor- and Attorney-General for Ireland (I88I-I883, I883), Master of the Rolls (I883I906).

${ }^{118}$ The committee was appointed in May I88г: Select Committee of the House of Lords on the Operation of Irish Jury Laws as regards Trials by Jury in Criminal Cases: PP I88I, XI, I. For Fitzgerald's evidence on venue changes, see pp. $454^{-} 457$.

${ }^{119}$ Not traced.

${ }^{120}{ }_{27}$ St Stephens Green, Dublin.

${ }^{121}$ On 2I May, Morley gave notice of an amendment to a proposal to renew the Crimes Act on the ground that the cessation of exceptional crime made it unnecessary: The Times, 22 May I885, p. 6, and see his letter to the editor (I June I885), The Times, 3 June I885, p. 8.
} 
great use of you so don't play yourself out but act with circumspection. I am glad you suggested to me the distinction between giving such a memorandum to a Cabinet minister \& giving it to an outsider, especially to a member who has given notice of a hostile motion on the subject dealt with by the memorandum".

\section{I May}

I today wrote to Sir Robert Hamilton, who is on a fishing excursion at Lough Sheelin, ${ }^{122}$ telling him I had prepared the memorandum \& forwarded it to Sir Charles Dilke \& telling him that if he wished to see a copy of it I should take one to him on his return to Dublin. I thought it more honourable and manly to write this to Sir Robert, lest he or Lord Spencer might fancy that I was plotting behind their backs.

I had a long talk on yesterday with William $\mathrm{O}^{\prime}$ Brien $\mathrm{MP}^{\mathrm{123}} \&$ also with T. Harrington MP. They believe that the ministry will not press any portion of the Crimes Act even though they may introduce a bill containing some of its provisions. Harrington says his mind inclines to the belief that at the General election the Irish party will aid Dickson MP and candidates of his stamp against the Tories in Ulster, but that nothing is yet decided. He does not think that the Liberals will have an overwhelming majority in England \& Scotland because he thinks that, as all constituencies will under the Franchise Act be 'one man' constituencies, ${ }^{124}$ local influences will be stronger than ever $\&$ that in the Counties local influences will tell for the Tories. O'Brien's view seems to agree as to this.

I urged O'Brien to direct his attention to working up in United Ireland $^{125}$ solid practical questions such as, the working of the new Constitution in Canada since the legislative functions were divided between one Central Dominion Parliament \& two Provincial Assemblies; the working of the new Constitution of Hungary since it obtained Autonomy ${ }^{126}$ the development of manufactures in Belgium; the local administration of Switzerland. He promised to do what he could in this direction but he said that it is very difficult to obtain writers competent to work up such subjects in an interesting manner. We discussed County Government \& a Central Assembly in Dublin.

\footnotetext{
${ }^{122} \mathrm{~A}$ trout fishery situated on the border between counties Cavan, Meath, and Westmeath.

${ }^{123}$ William O'Brien (1852-I928), Nat. MP for Mallow (I883-I887) and for Cork NorthEast (1887-I892), editor of United Ireland (I88I-I890), founder of the United Irish League (I900).

${ }^{124}$ In December 1884 , the Representation of the People Act abolished all two-member constituencies.

${ }^{125} \mathrm{~A}$ weekly newspaper established by the Land League in I88I.

${ }^{126}$ In 1867 , the Canadian Confederation was created by the British North America Act, and the Dual Monarchy of Austria-Hungary was established by the Ausgleich.
} 
He says that Parnell would not accept any settlement which would not leave to Irish control the Police Force of the whole of Ireland, nor would he consent to the Central Assembly being elected indirectly by the County Boards instead of directly by the constituencies.

He expressed a high opinion of Lord Hartington.

\section{June}

I went to the Four Courts ${ }^{127}$ today to see John Naish take his seat as Irish Lord Chancellor. I am 36 years of age \& I remember already to have seen eight different Irish Chancellors \& of them only two, viz. John Naish \& John Thomas Ball,,${ }^{128}$ are now alive. Eheu fugaces, Postume, Postume, labuntur anni! $!^{129}$

\section{June}

I dined last night with Dr. Nedley. ${ }^{1{ }^{10}}$ Among the guests was Sir Rowland Blennerhassett, ${ }^{131}$ MP for Kerry, who told some anecdotes of much interest. Among them was the following. In the year 1874 Sir Rowland was staying with Lord Acton ${ }^{132} \&$ Mr. Gladstone was also there. Sir Rowland \& Gladstone had one evening a warm discussion as to the abilities as a statesman possessed by the Duke of Wellington. ${ }^{133}$ Gladstone depreciated \& Sir Rowland praised him. Next morning Sir Rowland was walking in the demesne when Gladstone joined him \& renewed the discussion, \& as an instance of the folly and weakness of judgement shewn by the Duke in politics he told that on one occasion the Duke \& Sir Robert Peel, ${ }^{134}$ being members of the same Cabinet, the council was breaking up when the Duke who was standing with his back to the fire called Peel and said to him "Peel I wish you would turn

\footnotetext{
${ }^{127}$ Designed by James Gandon and built on Merchants Quay, Dublin (I786-I802), the seat of the Irish high court was named after its four oldest divisions: Chancery, King's Bench, Exchequer, and Common Pleas.

${ }^{128} \mathrm{John}$ Thomas Ball (I8I5-I898), Con. MP for Dublin University (I868-I875), Lord Chancellor of Ireland (1875-1880).

${ }^{129}$ 'Alas, Postume, Postume, the fleeting years are slipping by', the opening lines of Horace, Ode 2.I4.

${ }^{130}$ Thomas Nedley (1820-I899), surgeon to the vice-regal household and Dublin Metropolitan Police, member of Lord Randolph Churchill's Dublin circle: Roy Foster, Lord Randolph Churchill: a political life (Oxford, I98I), pp. 40-42.

${ }^{13}{ }^{1}$ Sir Rowland Blennerhassett (1839-1909), Lib. MP for Kerry (1880-1885).

${ }^{132}$ John Emerich Edward Dalberg Acton (1834-1902), first Baron Acton of Aldenham (1869), Lib. MP for Carlow (1859-1865), co-founder of The English Historical Review (1886).

${ }^{133}$ Arthur Wellesley (1769-1852), first Duke of Wellington (I8I4), Chief Secretary for Ireland (I806-I808), Master-General of Ordnance (I8I8-I822), Foreign Secretary (I8221827), Prime Minister (1828-1830).

${ }^{134}$ Sir Robert Peel (I788-I850), Chief Secretary for Ireland (I8I2-I8I8), Home Secretary (I822-I827, I828-I830), Prime Minister (I834-I835, I84I-I846).
} 
over in your mind how land transfer could be simplified in Ireland, I don't understand how it is to be done but I am quite satisfied that it must be done for unless the land system there be changed as to enlarge the number of owners of land, there will be a strike against rent before this century is over \& if that occurs then the resources of Constitutional Government will have been almost exhausted". This dictum Mr. Gladstone regarded as conclusive evidence of the Duke's want of judgement.

In Mr. Gladstone's Guildhall speech in I88I made as a prelude to the arrest of Parnell, Gladstone amid cheers said "Mr. Parnell will find that the resources of civilization are not yet exhausted". ${ }^{335}$ Sir Rowland says that this was clearly an allusion to the Duke's dictum \& was so understood by those who remembered the incident related by Gladstone to Sir Rowland.

Sir Rowland told a thing which was new to me, viz. that Lord Palmerston ${ }^{136}$ when Prime Minister urged J.D. Fitzgerald (now Lord Fitzgerald) to give up the bar \& accept the post of Chief Secretary for Ireland but that Fitzgerald said he could not afford to do it.

Sir Rowland says that Lord Spencer recommended Naish for the Irish Chancellorship but Gladstone was opposed to him \& in consequence the post was offered to Lord Fitzgerald but on the condition that if the bill now before Parliament for reducing the number of Irish judges \& reducing the salary of the Chancellor from $£ 8000$ to $£ 6000$ should pass, Lord Fitzgerald should take the reduced salary. ${ }^{137} \mathrm{He}$ refused the offer. Sir Rowland thinks that even then Naish would not have got the post only for Sir Henry Thring, ${ }^{13^{3}}$ the parliamentary draughtsman, who has a very high opinion of Naish $\&$ spoke very strongly in his favour to Mr. Gladstone. ${ }^{139}$

The conversation turned upon Mr. Trevelyan MP and Sir Rowland said that Mr. Trevelyan was anything but a well read man, even in the literature of the period about which he wrote. I said that his early years of Charles James Fox was a book not only very charming in style, but written apparently from an abundance of knowledge, \& that in

\footnotetext{
${ }^{135}$ The speech was delivered at Leeds Cloth Hall on 7 October I88I and Parnell was arrested six days later.

${ }^{136}$ Henry John Temple (1784-1865), third Viscount Palmerston (1802), Secretary of State for War (I809-I828) and for Foreign Affairs (I830-I834, I835-I84I, I846-I852), Prime Minister (I855-1858, I859-1865).

${ }^{137}$ Bill to amend Supreme Court of Judicature Act (Ireland), I877: PP I884-5, V, 531.

${ }^{138}$ Sir Henry Thring (I8I8-I907), first Baron Thring (I886), Parliamentary Draughtsman (1850) and Counsel to the Treasury (1869). He prepared the Home Rule Bill of r886.

${ }^{139}$ Gladstone finally conceded to Spencer's request when Fitzgerald endorsed Naish as the best administrator among the candidates: Spencer to Gladstone, I8, 24, 26, and 29 April, 6 May 1885; Gladstone to Spencer, 25 April, 8 May I885; Edward Hamilton to Spencer, 6 and II May i885: AP, Add MS 76862.
} 
reading it one was led to feel that the author was using up only a very few of a large quantity of material in his mental store. ${ }^{140}$ Sir Rowland as an example of the narrow range of Mr. Trevelyan's reading said that on one occasion he (Sir Rowland) asked him what he thought of some statement in De Tocqueville's Ancien Regime et la Revolution ${ }^{141}$ \& to his astonishment he found that Trevelyan had never read the book or even heard of it.

I knew Mr. Trevelyan pretty well when he was here as Chief Secy $\&$ it certainly did surprise me to find how few books he had in any of his rooms. Indeed it would be little exaggeration to say that he had not any books at all \& his pictures as he told me himself one day were not his, but belonged to Jephson, ${ }^{1{ }^{42}}$ his private secretary, who removed them when he married the rich London girl who has set him up in life.

\section{June}

Sir Rowland Blennerhassett came out to me today to Ballybrack to lunch after which we had a chat of several hours duration while we smoked our cigars. He had previously sent me the Contemporary Review for June 1885 containing an article by him on Peasant Proprietorship in Ireland in which, after giving much information of interest on the subject of the creation of an occupying proprietary in foreign countries, he recommended the establishment in Ireland of a Land Commission to purchase from such landlords as would be willing to sell their lands at 22 years ['] purchase of the judicial rent. ${ }^{143}$ We discussed this article \& I dissented from many of its recommendations \& I told Sir Rowland that in my opinion Irish landlords as a rule were not likely to get more than I5 or 16 years['] purchase of their rents. He said that the article was written by him last year to influence Mr. Gladstone \& to induce him to bring in a land purchase bill \& that it had been privately printed \& circulated among the members of the Cabinet. ${ }^{144}$ He believed it did not convert Gladstone who has previously been opposed to any purchase scheme. I knew that Gladstone had been opposed to the policy of aiding purchase by tenants on anything like a large scale \& I told Sir Rowland the following anecdote in

${ }^{140}$ The Early History of Charles Fames Fox (London, I880).

${ }^{141}$ Charles De Tocqueville, L'Ancien Regime et la Revolution (Paris, I856).

${ }^{142}$ Henry Jephson (1844-19I4), private secretary to the Under-Secretary and Chief Secretary of Ireland (1872-1884), he married Julie Reiss in I884. His works include The Platform: its rise and progress (London, I892).

${ }^{143}$ 'Peasant proprietors in Ireland', Contemporary Review, 47 (June I885), pp. 866-88I.

${ }^{144}$ See W.F. G[ullinan], 'Purchase of land (Ireland). Notes on the various schemes proposed from time to time', 3o June $\mathrm{I}_{885}$ : $\mathrm{CAB} 37 / \mathrm{I}_{5} / 35$. 
connection with land purchase. When Gladstone's Land Bill of $\mathrm{I}_{88} \mathrm{I}^{145}$ was passing through Committee I urged Charles Russell to move that the entire purchase money should be addressed. I could not persuade him to do this but I did induce him to propose an amendment in favour of advancing four-fifths of the purchase money. He moved this amendment whereupon Gladstone left his seat on the Treasury Bench, came to Russell sat down beside him \& said "Don't press this amendment, it is a small thing in itself as the difference between $3 / 4$ $\& 4 / 5$ is trifling but moreover it is unnecessary for believe me I have made the tenure clauses of the bill so attractive that I shall by them wean the Irish peasant from the idea of purchasing his holding". ${ }^{146}$

Sir Rowland capped this by telling me that when some years ago he in conversation said to Gladstone that it was absolutely necessary for permanent peace in Ireland to bring about a sale of a large part of the land here to the tenants, Gladstone roundly accused him of trying to undermine the Irish landlords \& to render society here wholly democratic.

We alluded to the effect produced upon Irish politics by the execution of the Manchester Martyrs a propos of which Sir Rowland mentioned at the time of their conviction D'Israeli $[\mathrm{sic}]^{147}$ was in power \& he was anxious that Allen, O'Brien \& Larkin should not be hanged, but Gladstone let it be conveyed to him that any reprieve should be denounced by him, Gladstone. Sir Rowland knew that this was so by reason of a communication which he had at the time with Lord O'Hagan, then Judge O'Hagan. ${ }^{14^{8}}$ O'Hagan had been a pet of Gladstone's \& Sir Rowland knowing this urged O'Hagan to write strongly to Gladstone to get him to use his influence in favour of commuting the capital sentence. Gladstone replied in a letter couched in what Sir Rowland calls 'The English Grocer politician's style' denouncing the idea of asking for a reprieve \& telling O'Hagan that he, Gladstone, felt it was intolerable that in the first centre of England's manufacturing industry a policeman should be shot down, \& that he, Gladstone, would denounce any attempt to obtain mercy for, or a remission of the capital sentence passed upon Allen, O'Brien \& Larkin. Disraeli had in this as in many other instances a true instinct; Gladstone had no instinct at least for Irish affairs. He has reasoning

\footnotetext{
${ }^{145}$ Bill to Further Amend Law Relating to Occupation and Ownership of Land in Ireland: PP I88I, III, 7.

${ }^{146}$ For Russell's proposed amendments, see Hansard, CCLXI-CCLXIII.

${ }^{147}$ Benjamin Disraeli (1804-188I), first Earl of Beaconsfield (I876), Chancellor of the Exchequer (I852, I858-I859, I866-I868), Prime Minister (I868, I874-I880).

${ }^{148}{ }^{8}$ Thomas O'Hagan (1812-I885), first Baron O'Hagan (I870), Lib. MP for Tralee (I8631865), justice of Common Pleas (1865-1868) and Lord Chancellor of Ireland (1868-1874, I880-I88I).
} 
power \& he has a desire to do right, but he never understands an Irish situation intuitively. For example, it is amusing to hear that when Gladstone came over to Ireland shortly after having written his pamphlet on 'Vaticanism', ${ }^{49}$ he mentioned that the cordial reception afforded to him by priests \& people shewed that the Irish clergy were of his mind as regards 'Vaticanism' \& were opposed to Pope Pius the $9^{\text {th }} .{ }^{5^{\circ}}$ Disraeli would never have made such a blunder. Again, Disraeli as far back as 1870 saw that for the stability of society in Ireland it was necessary to increase the number of owners of land here, \& he was anxious that the entire fund arising from the disestablishment of the Irish Church should be used as a guarantee fund to save harmless the state against loss in a big scheme for sale to tenants in Ireland, but Lord Cairns ${ }^{15 t}$ opposed him \& he therefore kept his counsel to himself. ${ }^{152}$ (This anecdote was told to me about 18 months ago by the Marquis of Waterford. ${ }^{153}$ ) In this instance his instinct was right, while Gladstone shews that he lacks instinct.

Disraeli was an awful sinner against Ireland. He saw the light, but he deliberately avoided it because it did not suit him to follow it. Gladstone has sinned through what theologians call invincible ignorance'.

When Sir Rowland was at the University of Berlin he became acquainted with Prince Bismarck ${ }^{154} \&$ he has kept up the acquaintance ever since. He has a very high opinion of his massive sense. Bismarck is in public awfully rude, in private life Sir Rowland says that he is only rude if he happens to dislike you, but if he regards one with favour or thinks that there is anything in one, he is very pleasant \& courteous. His mainspring politically is 'Socialism'. He regards the struggle between Capital \& Labour as the great problem of the near future \& all his influence is exerted to increase the share of profit now conceded to Labour by Capital. He is detested by the big merchants of Germany $\&$ it is owing to the preponderance of merchants \& manufacturers or,

\footnotetext{
${ }^{149}$ The Vatican Decrees and Vaticanism (London, 1874) and Vaticanism: an answer to replies and reproofs (London, I875).

${ }^{150}$ Giovanni Maria Mastai-Ferretti (I792-I878). As Pope Pius IX (I846-I878), he promulgated the dogma of papal infallibility.

${ }^{151}$ Hugh McCalmont Cairns (1819-1885), first Earl Cairns of Garmoyle (I867), Con. MP for Belfast (I852-1866), Lord Justice of Appeal (I866-I868), Lord Chancellor (I868, I874-I880).

${ }^{152}$ See E.D. Steele, Irish Land and British Politics: tenant-right and nationality $1865^{-70}$ (Cambridge, 1974).

${ }^{153}$ John Henry de la Poer Beresford (1844-1895), fifth Marquess of Waterford (I866), Lib. MP for Co. Waterford (I865-1866).

${ }^{154}$ Otto Eduard Leopold, Prince von Bismarck (1815-1898), Prime Minister of Prussia (1862-I873, I873-I89o), Chancellor of Germany (187I-I89o).
} 
in other words, of representation of capital in the German Parliament that Bismarck is so often defeated in the Chamber. ${ }^{155}$

Bismarck demands a strong Central Government for dealing with foreign affairs but for domestic purposes he is quite opposed to centralisation. For example he had always opposed the substitution of an Imperial sign on the coinage, in place of the sign of the country, duchy or whatever it may be which issues the coin. Prussia has on its coins the head of King William, ${ }^{156}$ Bavaria has on its coin the head of its own chief \& Bismarck says that it should so continue.

Sir Rowland says that Sir Henry Thring is opposed to the renewal of any part of the Crimes Act, he (Sir Henry Thring) says "Those $\mathrm{d}$ - d fellows at Dublin Castle are always asking for more powers even when they have them already". ${ }^{157}$

Sir Rowland expressed a high opinion of the straightforwardness \& ability of the Marquis of Hartington. I told him that Wm O'Brien had said much the same thing \& he told me that the Marquis of Hartington had told him that he held a high opinion of Wm O'Brien because he was so transparently honest.

We spoke about the prospect of the Crimes Act smashing up the ministry, Sir Rowland believes that the Crimes Act renewal bill will not alone not be pressed but that it will not be even introduced \& that still Lord Spencer will not resign.

\section{June}

While I was writing this last night the note of my conversation with Sir Rowland Blennerhassett, Mr. Gladstone was fighting in the House of Commons the death struggle of his ministry. Mr. Childers, ${ }^{1,5^{8}}$ the Chancellor of the Exchequer, had to provide i m millions sterling for war expenses in the Sudan \& Afghanistan. He proposed to raise this sum partly by an increase in the Income Tax and partly by an increase of 2/- per gallon on whiskey and a slight increase on beer. Against the increase of the whiskey \& beer duties the Irish party \& the Conservatives united with the result that at half past one of the morning the ministry was defeated by 12 votes. ${ }^{159}$ The Irish party was

\footnotetext{
${ }^{155}$ See Rowland Blennerhassett, 'Prince Bismarck', Nineteenth Century, 26 (June I89o), pp. $688-707$.

${ }^{156}$ Wilhelm of Hohenzollern (1797-I888), King of Prussia (I86I-I888), Emperor of Germany (1871-1888).

${ }^{157}$ For Thring's formal position, see his 'Procedure for Trial (Ireland) Bill: memorandum', 6 June I885: AP, Add MS 77331.

${ }^{158}$ Hugh Culling Eardley Childers (I827-I896), Lib. MP for Pontefract (I860-I885) and for Edinburgh South (I886-I892), Chancellor of the Exchequer (I882-I885), Home Secretary (I886).

${ }^{159}$ The motion was rejected by $264: 252$. See Hansard, CCXCVIII, col. I5II.
} 
organised for the fray very quietly, no preliminary public whip was made but the members were quietly got over from Dublin \& elsewhere $\&$ a solid muster of 38 of the party surrounded Parnell. They marched in a body into the opposition lobby and when a few minutes later the division list was handed to the opposition teller and it was known that the Government was defeated a scene ensued which beggars description. Lord Randolph Churchill ${ }^{60}$ stood up on the seat and whirled his hat round his head yelling like a red indian, the contagion spread like wildfire, Healy, O'Brien \& almost the entire body of Irish members with one accord burst into a roar of "coercion", "Spencer", "Buckshot". ${ }^{61}$ The uncontrolled excitement lasted for several minutes, Parnell being apparently the only cool man present. His only sign of emotion was a slightly increased pallor of the cheek.

Trevelyan said to Sir Wm. Harcourt ${ }^{162}$ (I suppose not intending his observation to be overheard but it was overheard by Dawson ${ }^{163}$ ) "I knew that Lord Spencer would do it".

Mr. Gladstone moved the adjournment of the House till today.

On reaching my office this morning I found awaiting me a letter from Mr. Joseph Chamberlain MP, the President of the Board of Trade, reminding me that he had been introduced to me some time ago in London and asking me to get him information on the following points

I. The details of the system - list and functions of the several local authorities in Ireland, their composition and mode of election or nomination \& details as to the system of Castle Administration.

2. Illustrations of the delay, irritation, inefficiency or extravagance produced by this highly centralised \& non-representative administration. ${ }^{164}$

${ }^{160}$ Lord Randolph Churchill (I849-I895), Con. MP for Woodstock (1874-1885) and for Paddington South (1886-1890, I892-1895), Secretary of State for India (I885-1886), Chancellor of the Exchequer (I886).

${ }^{161}$ A reference to a former Irish chief secretary, William Forster, who had authorized the use of buckshot as a 'non-lethal' alternative to round shot when policing Land League demonstrations: Stephen Ball, 'Crowd activity during the Irish Land War, I879-9o', in Peter Jupp and Eoin Magennis (eds), Crowds in Ireland, c. I720-I920 (Basingstoke, 2000), pp. 2I2-248.

${ }^{162}$ Sir William George Granville Venables Vernon Harcourt (1827-1904), Lib. MP for Derby (I880-I895), Home Secretary (I880-I885), Chancellor of the Exchequer (I886, I892I895), professor of international law, Cambridge University (I869-I887).

${ }^{163}$ Charles Dawson, Nat. MP for Co. Carlow (I880-I885), Lord Mayor of Dublin (I8821883).

${ }^{164}$ See Document 10. 
I also found a long letter from Escott, the Editor of the Fortnightly Review, enclosing a rough draft of an article on local government in England, Ireland \& Scotland written by or at the direction of Chamberlain and asking me as a personal favour to lick the Irish portion into shape. His letter is very urgent and he says in it that I can have as much space as I wish in the Fortnightly Review for the Irish portion of the article. I replied stating that I would be in London on the morning of the $12^{\text {th }}$ inst \& that I would call on him with all the materials which I can collect.

I called to the Castle to see Sir Robert Hamilton who wrote to me on yesterday asking me to let him see my memorandum on the Crimes Act. He was in very low spirits. He acknowledged that any renewal of the Act was now hopeless and he is in dread that intimidation will raise its head afresh and in a formidable shape \& that he will not be able to cope with it by the ordinary law. ${ }^{165} \mathrm{He}$ was really affected as he spoke to me \& almost with tears in his eyes he said that he was grieved to the heart to see men whose good intentions he recognised working against him to prevent the Executive getting powers which he believed essential to peace \& quiet in Ireland. I said "Sir Robert I have worked against you in this matter \& I have used every means to persuade you \& others that there is no part of the Crimes Act essential, but I plainly tell you I should be doing an unkind as well as a mean action if I told you anything which I did not honestly believe. My judgement may be wholly wrong but anyway if I am to be of any use to you or to Ireland it is by honestly proclaiming not what is palatable but what I believe to be true". He shook my hand warmly \& I don't think my sturdy stand against his opinion \& wishes will lessen, but rather I think it will tend to cement, our friendship.

Later in the day I saw Sir Robert for a moment \& he told me that Mr. Gladstone has resigned \& that he would go tonight to Balmoral to place his resignation in the hands of Her Majesty.

I2 June

I arrived in London this morning and am staying with Charles Russell QC for a few days. I called on Mr. Chamberlain and had a discussion of about an hour's duration with him on the subject of the article for the Fortnightly Review on Local Government in Ireland. His scheme is

(a) County Councils elected one third by landlords \& two thirds by tenants

\footnotetext{
${ }^{165}$ Hamilton had stated, 'I cannot conceive of anything which would be more disastrous to the preservation of order than that the idea should get abroad that intimidation is no longer a crime': Hamilton to Spencer, 6 June I885: GP, Add MS 44312, fos I45-146.
} 
(b) Gentral Assembly in Dublin elected by the County Councils but in the election the representatives of the landlords \& tenants respectively on the County Councils would vote separately eg if the number of members to be sent by each County Council to the Central Assembly should be 3, the landlord representatives should elect one member \& the tenant representatives should elect 2 members. He justifies this proposition by saying that the local taxes are contributed in the proportion of $1 / 3$ by landlords $\& 2 / 3$ by tenants. What he told me satisfies me that he \& Parnell have discussed the matter \& that the scheme proposed is the result of an understanding between them. I have promised Escott \& Chamberlain that I will write the entire article.

Chamberlain told me that while the fight in the Cabinet about the Crimes Act was going on, he \& Dilke wanted to get the above scheme introduced into Parliament this session. It would have been a tough job to carry it but they were prepared to go to work at once on it \& make a great effort to get it through this session. This information tallies with what I heard from John Morley on the $27^{\text {th }}$ May.

I learned a strange thing today. The Prince of Wales recently met Charles Russell \& he spoke very earnestly to him about the Crimes Act \& in favour of its renewal. Russell took a determined stand against its renewal \& the Prince urged him strongly to modify his attitude \& withdraw from opposing the renewal. Russell would not budge an inch \& he believes that the action of the Prince is the result of his recent visit to Lord Spencer. ${ }^{166}$

The Queen has accepted Mr. Gladstone's resignation.

\section{I5June}

I completed the article on local government last evening \& took it this morning to Escott. He was surprised at the rapidity with which I had done it.

I attended at the opening of the House of Commons today \& witnessed a curious scene. The first order of the day was the consideration of the Lords amendment in the Redistribution of Seats Bill. Sir Drummond Wolfe $[s i c]^{167}$ moved the adjournment of the question on the ground that the Lords had introduced into [the] bill clauses for accelerating the completion of the revision so as to allow the new election to take place in November. Sir Charles Dilke

\footnotetext{
${ }^{166}$ The Prince of Wales paid a state visit to Ireland in April 1885 (see Journal 24 February, 4 May 1885).

${ }^{167}$ Sir Henry Drummond Wolff (I830-1908), Con. MP for Portsmouth (1880-I885), member of Churchill's 'fourth party'.
} 
explained that these clauses had been introduced at the insistence of Lord Salisbury to save both houses the trouble of considering a separate bill for the purpose. Sir Stafford Northcote ${ }^{168}$ confirmed Dilke's statement \& therefore everyone expected to see Sir D. Wolfe's [sic] opposition collapse, but instead of any collapse what occurred was that Lord Randolph Churchill stood up \&, throwing over both Lord Salisbury \& Sir Stafford, vigorously supported Sir Drummond Wolfe's [sic] motion \& to the still greater surprise of everyone present, up stood Sir Michael Hicks Beach ${ }^{169} \&$ took the same line. A division was challenged with the result that into the Government lobby walked Sir Stafford Northcote \& Sir Richd. Cross, ${ }^{170}$ \& into the opposition lobby walked Lord Randolph Churchill, Sir Michael Hicks Beach, $\mathrm{Chaplin}^{171}$ \& several other prominent Tories. The division showed 33 $\mathrm{I}$ for the ministry \& 35 for the Churchill opposition. ${ }^{172}$

The division is a subject of amusement to the Radicals who consider the new ministry as broken up before it could be formed.

I6 June

Lord Randolph Churchill has triumphed. Sir Stafford Northcote has been thrown over by Lord Salisbury. He is not to lead the House of Commons but is to be 'kicked up stairs'. He takes a peerage \& some office of dignity \& unimportance, Lord Privy Seal or some such post. ${ }^{173}$ Sir Michael Hicks Beach is to be Chancellor of the Exchequer \& leader of the House of Commons \& Lord Randolph is to be Secretary of State for India with a seat in the Cabinet.

\section{I7 June}

I got the proof of the article on local government this morning \& having revised it I took it to Escott. He asked me to see Chamberlain about it. I did so \& I found him writing out a speech which he is to

\footnotetext{
${ }^{168}$ Sir Stafford Henry Northcote (1818-1887), first Earl of Iddesleigh (I885), Con. MP for Devon North (1866-1885), Chancellor of the Exchequer (I874-1880), First Lord of the Treasury (I885-I886), Foreign Secretary (I886-I887).

${ }^{169}$ Sir Michael Edward Hicks Beach (I837-I9I6), first Earl St Aldwyn (I9I5), Con. MP for East Gloucestershire (1864-I885) and for Bristol West (I885-I906), Chief Secretary for Ireland (I874-I878, I886-I887), Chancellor of the Exchequer (I885-I886, I895-I902).

${ }^{170} \mathrm{Sir}$ Richard Assheton Cross (I823-I9I4), first Viscount Cross of Broughton-in-Furness (1886), Con. MP for Lancashire South-West (I868-I886), Home Secretary (I874-188o, I885-1886), Secretary of State for India (I886-I892).

${ }^{171}$ Henry Chaplin (1840-1923), first Viscount Chaplin (I916), Con. MP for MidLincolnshire (I868-I906), Chancellor of the Duchy of Lancaster (I885-I886).

${ }^{172}$ The result was $333: 35$. See Hansard, CCXCVIII, cols I540-I555.

${ }^{173} \mathrm{He}$ was appointed First Lord of the Treasury.
} 
deliver tonight at Holloway, ${ }^{174}$ so I arranged to call on him on Friday next to discuss the article.

I saw Lord Randolph Churchill at the Carlton Club \& had a long talk with him about Ireland. ${ }^{175} \mathrm{He}$ asked me did I believe the ordinary law was sufficient to keep the peace in Ireland. I said yes \& he then told me he had all along opposed coercion \& that he believed it was to his action that the Irish party might attribute the abandonment of coercion because his action had stimulated the Radicals to take up a strong attitude in opposition to coercive legislation for Ireland. He is in favour of County Boards in Ireland but he saw great difficulties in giving a National Council, but he thinks that if the Tories come in at the General election they will offer to the Irish party a scheme of local government for Ireland so wide that the Irish party will be sorry to lose it. He does not believe it is probable that the Tories will have an absolute majority at the election because they have against them Ireland, Scotland \& Wales, but he said "If our party show sense \& courage we may at the election win 280 seats \& this number would enable us to carry on the Government by an understanding with the Irish party."

He has a great admiration for Parnell whom he considers a greater man than O'Connell. ${ }^{176} \mathrm{He}$ says that Parnell's instincts are Parliamentary \& Constitutional \& he looks to him as a Conservative force among the Irish party after the election, when there will be probably many new \& young men in this party whom he will have to control.

We spoke about Lord Spencer \& I said that while I had a high opinion of Lord Spencer's character I regarded him as a man who from his condition of mind could never understand Ireland. Lord Randolph said "I have a very poor opinion of Lord Spencer, I have always told his colleagues that it was a gross blunder to make him Lord Lieutenant of Ireland for he is a small minded, vain, obstinate, dull man".

I find that on the subject of land purchase in Ireland Lord Randolph is in favour of allowing any scheme for the purpose to be carried out by the County Boards to whom, \& not to the tenant farmers, the state should advance money. ${ }^{177}$

\footnotetext{
${ }^{174}$ See The Times, 18 June 1885 , p. 7.

${ }^{175}$ See Dilke's diary, I3 July 1885 (copy): JCP, JC8/2/I; and Foster, Lord Randolph Churchill, p. 23 I.

${ }^{176}$ Daniel O'Connell (1775-1847), co-founder of the Catholic Association (I823), MP for Clare (I828-I847), founder of the Loyal National Repeal Association (I840), Lord Mayor of Dublin (I84I-I842).

${ }^{177}$ For Fottrell's position on this question, see Fottrell to Churchill, I3 July I885: RCHL I/6. 69o.
} 
The impression left upon my mind by my conversations with Chamberlain and Lord Randolph is that there is remarkably little difference between the political opinions held by one $\&$ those held by the other.

\section{I8 June}

I called on W.H. Smith $\mathrm{MP}^{178}$ this morning at his house no. 3 Grosvenor Place \& had a long and interesting conversation with him about Ireland. He asked me did I think that the ordinary law of the land would suffice to keep peace there \& I said certainly for this up to the meeting of the new Parliament, but that if there was then no attempt made to remedy the centralised system of government in Ireland so as to give power to the localities \& to Irishmen at home to manage local and domestic matters in Ireland there would be such a revulsion of feeling that a very serious agitation would at once begin \& that it might lead to crime. I also told him that the fact of last harvest having produced abundant food \& turf rendered any immediate outbreak of crime highly improbable. He said he quite understood my view but that the influence of a dry season in Ireland in producing comparative content by reason of an abundance of fuel was one which Englishmen could not understand.

He is evidently in favour of abandoning coercion of every kind. We discussed the question of land purchase in Ireland. He is quite opposed to Government fixing any definite number of years' purchase of the landlords' interest \& I think he would be anxious to let the Irish Counties borrow the purchase money on the security of the rates \& then lend it to the tenant purchasers. However, he thinks that possibly a measure might be carried this session to enable the entire purchase money to be lent direct by the state on the condition that the vendors should allow proportion of the purchase money to be retained for a certain number of years as a guarantee. He asked me what would I think of a plan which would hold out to the tenant purchaser an inducement to pay up his instalments more rapidly than contract would bind him to do, \& when I replied that if such a plan could be devised it would be most useful \& likely to be availed of he told me he had got calculations made very carefully which shewed him that an instalment of say $f_{\mathrm{I}} \mathrm{I} 2$ payable 35 years hence could without loss to the state be redeemed now by a payment of say $£ 5$, so that it would be possible to hold out a strong inducement to the tenant purchasers

\footnotetext{
${ }^{178}$ William Henry Smith (I825-I89I), Con. MP for Westminster (I868-I89I), Secretary of State for War (1885, I886), Chief Secretary for Ireland (1885-1886), First Lord of the Treasury and Leader of the House of Commons (1887-I89I).
} 
in a good year to pay up more than the year's instalment. This seems very simple \& I told him I thought it would be effective.

\section{I9June}

I saw Chamberlain today at his house. We discussed the article which I had written for the Fortnightly Review \& he expressed himself much pleased with it \& said "it will kick up the devil of a row". He mentioned that before he had written the memorandum which had been sent to me as the basis of the article, he had obtained from Parnell a written memorandum of his views on the subject \& in Parnell's memorandum there was no mention made of handing over the control of the police to County Boards or to the National Council. ${ }^{179}$ He therefore struck out the sentence in the article which stated that the control of the police should be vested in the County Boards, but at the same time he said that he did so not because of his own unwillingness to entrust the police to the Board but because he feared the proposal might arouse bitter \& dangerous opposition. ${ }^{\mathrm{I} 0}$

The newspapers this morning referred to a hitch which had arisen in Lord Salisbury's arrangements for forming a Cabinet, but they did not state how the hitch had arisen. ${ }^{18 t}$ Chamberlain told me that Lord Salisbury had asked for a pledge from Mr. Gladstone's ministry on two points -

I $^{\text {st }}$ That the Liberals would not oppose any financial proposals which the new Government might make for raising taxes to pay the expenditure for the year or else that the new Chancellor of the Exchequer should be at liberty to pay the bills simply by issuing Exchequer bills \& thus tide over the difficulty till next year.

$2^{\text {nd }}$ That the entire time of the House of Commons should be given to the new Government till the end of the session. Chamberlain said that he had opposed the proposition to give such pledge which he considered manifestly unreasonable. The result of the deadlock might be that the Liberals would have to come back to power again. I said I hoped not, for I thought it would be much better for them to be free for the few months preceding the General election, to which Chamberlain replied that he agreed with me but that it was to be remembered that if the Liberals came back now, they would go into office on very different terms from those which existed before they had resigned,

\footnotetext{
${ }^{179}$ See William O'Shea's memorandum, i4 January i885: JCP, JC8/8/I/36, repr. The Times, I3 August I888, p. 8; and see 'A scheme for the improvement of local govt. in Ireland': AP, Add MS 77329 .

${ }^{180}$ See Richard Barry O'Brien, The Life of Charles Stewart Parnell, I846-I89I, 2 vols (London, I899), II, p. I38.

${ }^{182}$ See 'The political crisis', The Times, I9 June i885, p. 6.
} 
because coercion was now dead \& that was the only question about which the Cabinet was in danger, as under no circumstances would he \& Dilke have continued members of a Cabinet pledged to coercion. I said that if the Liberals returned to power he ought to come over to Ireland as Chief Secretary, but he answered that he would not do so, that they would put the Vice-Royalty in Commission, appoint a Chief Secretary who would not object to Dilke \& Chamberlain coming over to Ireland \& making speeches, \& that he \& Dilke were quite prepared to go over to Ireland in this fashion, but that it would be worse than useless for him to go over at present as Chief Secretary because he would not do better as Chief Secretary than any one else in as much as he, under the present system of Government, would have no bodies of authority \& persons of popular confidence to whom he could refer for information \& that he would therefore have to rely on the police.

\section{I June}

This being Sunday I arranged with Charles Russell to go down to Epsom to see the Country House, Tadworth Court, which he has bought \& for which he is paying $£ 22,000$. It is a very handsome old place with 150 acres of a park. The house is between $2 \& 3$ centuries old \& is very fine..$^{122}$

The political crisis still continues.

I9 [22] June

I today saw Oxford for the first time. Laurence Waldron \& young Charles Russell ${ }^{183}$ came with me. I was deeply impressed with the venerable \& artistic air of most of the Colleges, especially of Oriel, Trinity, Magdalen \& Christchurch.

\section{June}

The crisis is over. Lord Salisbury has not received the assurances which he asked for, but he received some general expression of good will from Gladstone.

I attended the House of Commons today \& heard Gladstone announce that Lord Salisbury had definitely accepted office. Mr. Gladstone immediately moved the adjournment of the House and then the members of Gladstone's ministry left the front bench on the

\footnotetext{
${ }^{182}$ The house was built by Leonard Wessel at Banstead in I694.

${ }^{18}{ }^{18}$ Charles Russell (1863-1928), son of Sir Charles Russell, solicitor to the Canadian government (I896).
} 
Government side of the House and on tomorrow they will take their places on the opposite bench. ${ }^{184}$

I dined with Mr. Chamberlain at his house, 40 Prince's Gardens. The party consisted of Sir Charles Dilke, John Morley, Jesse Collings, Chamberlain, his daughter and myself. The conversation during dinner was all political \& Miss Chamberlain ${ }^{185}$ joined in it \& seemed to understand the drift of it very well. Chamberlain asked me to get him definite information as to the personnel of the Irish Board of National Education, \& as to the powers of the board and also as to the amount of interference exercised by the Local Government Board on Municipal Councils \& Boards of Guardians in Ireland.

Chamberlain is personally in favour of handing over the control of the police to elective County Boards in Ireland. My opinion was asked \& I said that while theoretically it would be right to vest control of the police in the Boards, I could not conceal from myself as a practical politician that the transfer of police jurisdiction to popular boards would at present be a dangerous experiment because I felt satisfied that in agrarian disputes for rent \&c. the popular boards would not aid the Sheriff in carrying out unpopular proceedings. Morley took my view \& quoted a statement made to him a couple of years ago by John Dillon MP ${ }^{186}$ who said "If you give us the police, the English control of Ireland is at an end". Collings took part against me, Dilke held his tongue.

I have now had a few opportunities of judging of Chamberlain \& of Dilke \& my impression is entirely in favour of Chamberlain as the abler $\&$ bigger man. Dilke is clever, knows a good deal \& has his knowledge carefully docketted. He has not a spark of genius nor a trace of humour. He is noisy \& self-assertive - tells stories without much point \& laughs loudly at them. He says things of his supposed friends which shew a womanly spite. I should say he has no political instinct but he reads his brief carefully \& is painfully accurate \& respectable. I think he knows that Chamberlain is his superior. They are very friendly \& seem to rely thoroughly on each other. I fancy that Dilke is a man without any bowels of compassion \& that he would ride roughshod over any one who stood in his way. Chamberlain has a much better manner than Dilke. He is more open \& less self conscious. He speaks frankly or, if not really frank, he is able enough to impress his hearers with his

\footnotetext{
${ }^{184}$ Hansard, CCXCVIII, cols I618-1622.

${ }^{185}$ Beatrice Chamberlain (1862-1918), eldest daughter and (prior to Chamberlain's second marriage in I888) chatelaine of his household: Peter Marsh, Foseph Chamberlain: entrepreneur in politics (New Haven, CT and London, I990), p. 3 or.

${ }^{186} \mathrm{John}$ Dillon (I85 ${ }^{\mathrm{I}-\mathrm{I} 927)}$, Nat. MP for Co. Tipperary (I880-I883) and for Mayo East (1885-1918), co-leader (with William O'Brien) of the Plan of Campaign (1886-1892), Deputy Leader of the Irish Parliamentary Party (I900-1918).
} 
frankness. He has political instinct \& his politics seem to have their root in a desire to improve the condition of the masses. I do not mean to say that he is not ambitious, but I do think that Chamberlain is capable of making personal sacrifices for the good of others \& I doubt if the same could be said for Dilke.

The new Lord Lieutenant for Ireland is to be Lord Carnarvon ${ }^{187}$ \& the Chief Secretary is to be Sir William Hart Dyke. ${ }^{188}$ We discussed the character of these politicians \& I found that all present had a very poor opinion of Lord Carnarvon. They say he is small \& antipetty. He means however not to be a cypher. He sent today for Courtney Boyle, Lord Spencer's late private secretary, \& for Mr. Campbell Bannerman, ${ }^{189}$ the Chief Secretary, to coach him on Irish affairs. Of Sir W. Hart Dyke the company agreed that he is a kindly good natured fellow with very little capacity. Edward Gibson, the Irish Lord Chancellor, is to have a seat in the Cabinet \& a peerage.

\section{June}

I met Sir Rowland Blennerhassett at the Athenaeum Club. He introduced me to Lord Houghton ${ }^{190}$ whom I was anxious to see as I remembered to have read somewhere that he said he had himself performed the miracle of the liquefaction of the blood of St Januarius. ${ }^{191}$ I asked him about this statement \& he told me that on one occasion he was travelling with the late Archbishop $\mathrm{McHale}^{192}$ in Italy and that they put up at the Convent in which the blood of St Januarius is deposited. It is kept in a cellar or underground cave. Dr. MacHale told the superior that Lord Houghton believed in the miracle whereupon the Superior said that Lord Houghton could next day hold the vessel containing the blood \& that he would see it liquefy. On the next day accordingly the vessel was brought up from the cave \& handed to Lord Houghton, who was told to hold it up before the people in the Church. He did so and the blood or whatever other

\footnotetext{
${ }^{187}$ Herbert Henry Howard Molyneaux (I83 ${ }^{\mathrm{I}-\mathrm{I} 890}$ ), fourth Earl of Carnarvon (I849), Colonial Secretary (I866-I867, I874-1878), Lord Lieutenant of Ireland (I885-I886).

${ }^{188}$ Sir William Hart Dyke (I837-I93I), Con. MP for Mid-Kent (I868-I885) and for Dartford (I885-I906), Chief Secretary for Ireland (I885-I886).

${ }^{189}$ Henry Campbell-Bannerman (I836-I908), Lib. MP for Stirling Burghs (I868-I9o8), Chief Secretary for Ireland (1884-I885), Secretary of State for War (I886, I892-I895), Prime Minister (1905-1908).

${ }^{190}$ Richard Monckton Milnes (1809-I885), first Baron Houghton (I863), Con. and Peelite MP for Pontefract (1837-I862), President of the London Library (I882-I885), scholar and advocate of religious equality.

${ }^{191}$ Patron saint of Naples. As bishop of Beneveto, he was beheaded in 304 during Diocletian's persecution of the Christians. The miracle is said to happen twice a year at the Duomo in Naples and at the Church of San Gennaro at Solfatara in Pozzuoli.

${ }^{192} \mathrm{John}$ McHale (I79I-I88I), Archbishop of Tuam (I834-I88I).
} 
substance was in the vessel did gradually change from a viscous substance to a fluid. Lord Houghton attributes the liquefication to the change in the temperature. The vessel is shaped somewhat like a carriage lamp \& the hand has of course considerable power of altering the cool temperature in which the vessel while in the cellar was placed.

Lord Houghton knew Daniel O'Connell. He remembers a conversation which they had about repeal of the Union, this took place about the year i847. Lord Houghton asked O'Connell did he consider Repeal feasible \& O'Connell replied, that he could not tell how long the change might take to come about, but he felt sure that in the long run Ireland would be politically connected with the only country in Europe of the same religion as herself, \& near enough to protect her, he meant France.

Sir Rowland Blennerhassett is doing his best to induce the Tory Cabinet to bring in a purchase bill for Ireland this session. I told him he might put out of his head all thought of inducing the Tories to propose a bill fixing the price at which the land is to be purchased.

A telegram has been this morning received from Rome announcing that the Pope has appointed Dr. Walsh Archbishop of Dublin.

\section{June}

Lord Spencer today held a farewell reception \& then left Ireland for good. I was detained in court all day \& therefore I was not able either to attend the reception or watch Lord Spencer's progress through Dublin on his way to Westland Row. ${ }^{193}$ I told him in confidence my share in the production of the article in the coming number of the Fortnightly on local government. ${ }^{194}$ Sir Robert asked me for the outlines of Chamberlain's scheme, \& when I had told them to him he asked me how Chamberlain proposed to deal with the question of ascertaining the amount to be contributed each year by the Imperial Exchequer to Irish domestic purposes. I said that Chamberlain proposed to leave this question to be dealt with each year by the Imperial Parliament. "Then", said Hamilton, "a serious danger will arise for on this side of the Channel you will have in the Central Council of Ireland a body possessed of national authority who will keep constantly demanding an increased contribution from the Imperial Exchequer, and if this

\footnotetext{
${ }^{193}$ See Fottrell to Spencer, 2 July I885: AP, Add MS 77152. Spencer made farewell visits on I9 June and departed from Kingstown on 22 June: The Times, 20 June I885, p. 12; 23 June I885, p. 6.

${ }^{194}$ 'The Radical Programme (No. VII): local government in Ireland', Fortnightly Review, 44 (July I885), pp. I-I6. For Gladstone's view of this article, see GD, XI, pp. 652-653.
} 
demand be refused there will be a risk of great friction between the National Council \& the Imperial Parliament. The National Council would then be opposed to the Imperial Parliament \& to whatever Executive would remain in Ireland to represent the Home Office, in whom the control of the police would be vested, \& no Executive could stand against the declared hostility of so strong a body as the National Council!".

Sir Robert then said "you have been very frank with me \& I shall now be frank with you. I recommended Lord Spencer to suggest to the Cabinet (a) the immediate establishment of County Boards with owners \& occupiers representatives on them (b) a Central Board elected partly by the ratepayers \& partly by the managers of the national schools throughout Ireland (c) that to this Central Board should be given the entire control of primary education in Ireland \& the distribution of the Imperial grant as well as of local contributors for education, the imperial grant to be definitely fixed at the figure which would represent the average of the last five years, such figure to remain fixed irrevocably for 5 years, leaving it to the Central Board to supply by local taxation any further money which might be needed".

This, said Sir Robert, "would have been a start in the direction of free local government. It would have trained Irishmen to undertake the work of administration while at the same time, as the Central Board would be one created to deal only with education, it would not have had such a strong position as would enable it to be a menace to the Executive in Ireland or to the Imperial Parliament." ${ }^{95}$

Before we could finish the discussion Sir Thomas Steele, ${ }^{196}$ Commander of the Forces, came in to consult Sir Robert Hamilton as to the necessity of providing a military escort for Lord Carnarvon, who is to arrive on Monday morning as Lord Lieutenant of Ireland $\&$ therefore I left \& adjourned our discussion till some other occasion.

28 July

Since I wrote the preceding note, events have moved quickly. Lord Carnarvon has assumed his duties as Lord Lieutenant \& has made himself quite a popular character. He drives about Dublin without an escort and he has made several speeches in answer to addresses and in many of these utterances he has shown a breadth of sympathy which is in strong contrast with the rigid replies of Lord Spencer, whose honesty of nature was appreciated by those

\footnotetext{
${ }^{195}$ See Document 9.

${ }^{196}$ Sir Thomas Montague Steele (I820-I89o), commander of Dublin military district (I872-1874), Commander-in-Chief in Ireland (1880-I885).
} 
few who know him well, but whose haughty, unintentionally haughty, \& cold demeanour rendered it impossible for him to impress Irishmen favourably.

Parnell has brought forward a motion for an enquiry into the Maamtrasna, Barbavilla, \& Crossmaglen convictions \& he rested his case mainly upon the first named of these cases. ${ }^{197}$

The Tory Government yielded in the main to his motion. They refused a public enquiry, but they promised that the Lord Lieutenant would himself carefully enquire into the cases. As a result of this concession there has been a furious howl from the Liberal press in England \& the Tories are denounced as traitors and immoral politicians because they have "surrendered to Parnell". It will be interesting to watch whether this alleged agreement with Parnell will seriously injure the Tory party in England at the General election.

Edward Gibson, the Irish Lord Chancellor, has been created a peer under the title of Lord Ashbourne. He has introduced a Land Purchase Bill which if it passes ought to do a deal of good to this country by promoting the purchase by tenants of their holdings. ${ }^{198} \mathrm{I}$ had some slight influence on the policy of the Bill. I was asked by Robert Holmes to call on Lord Ashbourne in reference to the Bill which it was known he was preparing. I did so \& I soon saw that his notion was to leave the working of the bill to one of the existing Land Commissioners \& to one additional Commissioner. I pointed out to him that if he followed this line his bill would inevitably fail because there was not a possibility that the existing commissioners could perform successfully their present work of dealing with appeals from the sub Commissioners, much less perform that work plus the work of land purchase. He then asked what would I suggest. I said that the best thing would be to appoint a separate Commission \& give them power to utilise such portions of the Land Commission staff as might be suitable for the purposes of this work. I pointed out that 2 Commissioners would probably suffice for the work at the beginning \& that a salary of $£ 2000$ a year would command good men. Lord Ashbourne said the session was so far advanced that it would be impossible in the time at the disposal of the Government to elaborate a scheme for appointing an entirely fresh Commission \& that the new man or men selected should be grafted on the existing Commission. I replied that if they were to be grafted they should be

\footnotetext{
${ }^{197} \mathrm{On}$ I7 July, Parnell requested that the government 'institute strict inquiry into evidence' surrounding these and two other 'agrarian' cases: Hansard, CCXCIX, cols Io64-II50.

${ }^{198}$ Bill to Provide Greater Facilities for Sale of Land to Occupying Tenants in Ireland: PP I884-5, II, 305; Hansard, CCXCIX, cols I040-I049.
} 
grafted in such a way as would leave them entirely independent of the existing Commissioners, for if not failure was inevitable. He asked me whom would I suggest as Commissioners. I said Mr. Edmund Murphy ${ }^{199}$ of Dunfanaghy, the Board of Works Arbitrator, was in my opinion the man best suited of all the men I knew for the post of Commissioner \& that he certainly ought to be selected as one of the new men, \& as for the other I said that the Government ought to try to get a man like myself. I said that I mentioned myself with perfect freedom in as much as the post would be no gain to me at all, because my present post of Clerk of the Crown \& my private practice placed me financially in fully as good a position as a Commissionership could do.

Lord Ashbourne adopted my suggestions in the main points. John Dillon has come back from America. ${ }^{200} \mathrm{He}$ seems to be in excellent health. He spent last Sunday fortnight with me \& we had a long talk about Irish affairs. I explained to him what I had done in connection with the article in the Fortnightly attributed to Chamberlain. He agreed with me that it was a gain to get Chamberlain committed even so far. He, John Dillon, is anxious that the process of obtaining freedom of Government in Ireland should be gradual, for he believes that the more gradual it is the more usefully it will be availed of by the Irish nation. I told him that Chamberlain's own view is that the control of the police should be vested in the County Boards. John Dillon said that if County Boards were established \& if large powers of taxation \& of local control were vested in them, it was inevitable that the control of the police should be soon given to these Boards, because once it became apparent that the police force was being maintained merely to assist landlords in getting their rents, the English people would kick against paying an enormous yearly sum merely for the benefit of Irish landlords, \& the Irish people would never consent that the charge of this huge force should be thrown on Irish rates unless control of the force was vested in Irish boards.

We spoke about the Land Purchase Bill. John Dillon's opinion is that it will be availed of largely if the landlords shew a willingness to accept reasonable prices for the land, \& if they do not he thinks there will be something like a strike against rent so as to bring the landlords to their senses. His view is that the purchase price of Irish land will be almost i6 years['] purchase of the judicial rent. Sir Robert Hamilton

\footnotetext{
${ }^{199} \mathrm{He}$ later served briefly on the Evicted Tenants Commission: Ff, I5 October I892, p. 5 .

${ }^{200}$ In I883, Dillon temporarily withdrew from politics and spent two years on his brother William's ranch at Castlerock, Colorado: F.S.L. Lyons, Fohn Dillon (London, 1968), pp. 70-7I.
} 
says about 15 years['] purchase is the figure he would prophesy as the average.

On last evening I had a very interesting dinner party here at Dunmera. ${ }^{201}$ The company was Sir Charles Gavan Duffy, ${ }^{202}$ Sir Robert Hamilton, Lord Justice Barry, ${ }^{203}$ Professor Galbraith, ${ }^{204}$ Richard Owen Armstrong, ${ }^{205}$ Laurence Waldron, Major Miley, ${ }^{206}$ my father ${ }^{207}$ \& myself. After dinner we had a long discussion on the subject of Home Rule. Duffy propounded the proposition that it would be safer to grant a separate Parliament at once to Ireland than to begin by establishing County Boards and a Central Council such as Chamberlain suggested. Hamilton took the opposite side. I suggested that the main difficulty was the question of landlord \& tenant, because if complete freedom of legislation were conferred on the Irish Parliament there would be a risk of the landlord's interest being practically confiscated. Duffy said that this difficulty could be met. I asked how. He replied by enacting in the Act giving the separate Parliament a provision that there should not be any compulsory expropriation of landlords, \& that in the Act a maximum price of say 20 years['] purchase should be fixed as the limit for state advances for purchase, but that subject to this maximum limit both landlord \& tenant should be left free to bargain for the price of all land to be sold. Duffy suggested that provisions could also be inserted for securing full freedom to Protestants against Catholic oppression. I said that I believed such provisions would be wholly unnecessary as there was really no danger of Catholics in Ireland striving to oppress Protestants.

I suggested as the next greatest danger the question of a protective tariff. Duffy met this by saying that a provision could be introduced prohibiting the imposition of a protective tariff, but leaving liberty to the Irish Parliament to grant bounties if they thought it wise to do so. He believes that such bounties would be \& ought to be given.

\footnotetext{
${ }^{201}$ His home at Ballybrack, Co. Dublin. A keen cyclist, Fottrell regularly made the round trip to his office in Dublin: Irish Times, 2 February 1925, p. 8.

${ }^{202}$ Sir Charles Gavan Duffy (I8I6-I903), founder of The Nation (I842), of the Irish Confederation (1847), of the Tenant League (1850), and of the Independent Irish Party (1852), Prime Minister of Victoria (1871-I872).

${ }^{203}$ Charles Robert Barry (I823-I897), Lib. MP for Dungarvan (I865-I872), justice of Queen's Bench, Ireland and Lord of Appeal (1872-1883).

${ }^{204}$ Joseph Allen Galbraith (1818-1890), professor of mathematics, Trinity College, Dublin, advocate of Irish home rule.

${ }^{205}$ Richard Owen Armstrong, Director of the Artisans' Dwellings Company of Dublin.

${ }^{206}$ James Miley (1846-I9I9), military officer on departmental staff (1875-I898), Secretary of Finance for the Military Department, Government of India (I898-I902).

${ }^{207}$ George Drevar Fottrell Snr (1813-1887), solicitor. Fottrell's mother, Ellen, had died in I867, aged forty-six.
} 
Hamilton asked would Duffy propose to have both an Irish Parliament \& Irish representatives in the Imperial Parliament. Duffy's reply was to the effect that he personally would care very little whether the Irish had representatives in the Imperial Parliament or not, provided that the Irish people were not called on to contribute to foreign wars but that his belief was that the best course for both countries would be:

(a) to fix now once \& for all the ratio of contribution by Ireland for ordinary Imperial purposes.

(b) to enact that Ireland should send representatives to Westminster.

(c) to enact that Ireland should contribute to the expense of foreign wars in the proportion of her ordinary contribution to Imperial expenses.

Hamilton said would not this give to Ireland more than Canada or any other British Colony possessed. I said no. Canada it is true has no representatives in the Imperial Parliament, but on the other hand she is not called on to contribute to Imperial expenses; the moment you decide that Ireland must contribute to the expense of foreign wars you must necessarily give her a voice in deciding whether or not such wars are to be undertaken.

I called today to the Castle to see Sir Robert Hamilton. I found him quite enthusiastic in his delight at our discussion of last evening. He was greatly struck with Duffy who he says is one of the most interesting men he has ever met. He told me that this morning he was with Lord Carnarvon to whom he mentioned where he had been dining last evening \& the company whom he had met, \& that he mentioned to Lord Carnarvon that my house was the only place where he was able to meet men in touch with the people. He detailed to Lord Carnarvon the whole discussion which we had \& which evidently has made a great impression on him (Hamilton). He said that there was one point suggested last evening about which he had grave doubts, viz. that if an Irish Parliament were granted at once there were many moderate men now without any influence on public affairs in Ireland who would seek to be elected to the Irish Parliament \& would form a moderate party there. He asked what was my opinion in the matter. I said that I felt satisfied there would be many moderate men who would obtain influence in an Irish Parliament but who were at present absolutely kept out of public life because they had nothing round which they could rally, they could not honestly support the existing order of things because they regarded it as a rotten condition of things, but they would rally round a man who in an Irish Parliament would seek to prevent headlong legislation. Hamilton said that if he were 
satisfied on this point he would be glad to see an Irish Parliament established at once.

We laughed at the way in which Chamberlain's suggestions in the Fortnightly Review of this month were derided last evening by all the company as being entirely inadequate. It is certainly a very good criterion of the rapidity with which we are moving to find that on the $27^{\text {th }}$ day of the month a scheme is, by a mixed company of Irishmen, decried as wholly inadequate which on the $\mathrm{I}^{\text {st }}$ of that month was denounced as revolutionary.

3o July

This mornings papers announce that Farquharson, the manager of the Dublin Branch of the Munster Bank, absconded on the day before yesterday \& that his accounts shew defalcations amounting to $f 70,000 .{ }^{208}$

I breakfasted this morning with Sir Charles Gavan Duffy at the Shelbourne Hotel. Our party consisted of Sir Charles and his wife, ${ }^{209}$ Sir Robert Hamilton \& myself. I had suggested to Duffy on the evening when he dined with me that it would be useful if he \& I and Hamilton could meet somewhere to have a quiet chat about Irish affairs \& acting on this hint he asked us to breakfast. When we had finished our meal Lady Duffy retired \& we lighted our cigarettes \& straightaway plunged into an animated discussion. Our subject was the establishment of an Irish Parliament. Hamilton remarked that he had been carefully considering the arguments put forward by Duffy at my house on the $27^{\text {th }}$ July in favour of the immediate establishment of an Irish Parliament, but that there was one matter about which he was in grave doubt, viz. how in such an assembly it could be secured that property would be adequately represented. Duffy replied that the difficulty had occurred to him and that he was satisfied it could be met in more ways than one, but that one way of effectually securing an adequate representation of property seemed to him quite feasible. His proposal was that Ireland should be divided into say 33 or 34 electoral districts corresponding in general to the Irish Counties \& that each district should return to the Parliament 3 members, but that each elector should be permitted to give not 3 but only 2 votes \& (as I understand his proposal) that our elector should be at liberty to give both his votes to one candidate. The result would be that the landlord

\footnotetext{
${ }^{208}$ Farquharson fled to Spain and subsequently evaded arrest: The Times, 30 July I885, p. IO; 3I July I885, p. Io; I August I885, p. 5; 3 August I885, p. 4 .

${ }^{209}$ Louise (née Hall), a niece of Duffy's second wife, Susan (d. 1878), became his third wife in I88I. They had four children before Louise died in childbirth in February I889.
} 
minority would file all their votes in favour of a single candidate in each constituency \& that they would thereby secure at the onset one third of the representation. With such a proportion secured to the landlords at the start they would, amid the ever varying contingencies of a Parliament, be able to make their influence felt because on many questions they would be able in practice to attract the support of a section of the non landlord representatives, \& a compact body of 33 members out of Ioo would always be so powerful a factor in divisions as to be certain of wielding substantial influence. Hamilton urged that such a system of minority representation would be a novelty in the history of the World, but Duffy promptly met the objection by pointing out that a system of representation such as he advocated had been for some years in operation in the Cape of Good Hope, where it had been found to work well. ${ }^{210}$ I pointed out to Duffy that the fact of both Hamilton \& myself being ignorant of the fact that such a system existed in the Cape of Good Hope was a strong argument in favour of the suggestion which I had made to him (Duffy) at a former interview, that he should write, for say the Freeman, a series of short articles describing the constitution of several colonies of Great Britain. He acquiesced in the wisdom of this suggestion \& promised to act on it.

I asked him would he propose to have in Ireland two chambers or only one. He replied "certainly two. I should have both a lower chamber or House of Commons \& an upper chamber or Senate. The Senate should consist of say 60 members, whose qualification should be laid down in the Act establishing the Parliament. They should consist for example of certain ex officio members, e.g. the Catholic Primate \& the Protestant Primate \& of members elected by a constituency more limited than that which would elect the members of the lower chamber, say for example that for the lower chamber the constituency should be founded on household suffrage and for the Senate that it should be founded on a $f, 20$ annual valuation. The first members of the Senate should be named in the Act of Parliament establishing the constitution and they should be selected so as to give a fair representation to the several schools of political opinion in Ireland".

Duffy considers that a constitution established on such a basis as he described would be absolutely a protection against any violent inroad upon the rights of property.

Hamilton was greatly struck with Duffy's views \& thanked him cordially for the information which he had given. After Hamilton \& I had taken our departure we walked together as far as Trinity College

\footnotetext{
${ }^{210}$ See Alpheus Todd, Parliamentary Government in the British Colonies (London, I880),
} pp. $64-74$. 
\& Hamilton spoke as if he considered that Duffy's views might be put into action in the course of the next few months.

I should mention that when Duffy had developed his views I said "but as a matter of practical politics what would you suggest as a means of giving prompt effect to your opinions". His reply was that the ministry should privately take counsel with Parnell as the recognized leader of the Irish people and that they should promise him privately that if they came back into power at the General election they would bring forward a scheme for establishing an Irish Constitution, \& that the details of the scheme should meanwhile be settled by a small private commission of say 5 or 6 men of whom Parnell should be one.

\section{$I^{\text {st }}$ August}

Hamilton has a very high opinion of Lord Carnarvon's abilities as well as his character.

$2^{\text {nd }}$ August

Dr. Walsh was today consecrated Archbishop of Dublin.

$5^{\text {th }}$ August

I saw Sir Robert Hamilton today at the Castle. He read for me a very full report which he had made immediately on his return from breakfasting with Sir Charles Gavan Duffy on the $\mathrm{I}^{\text {st }}$ inst. ${ }^{211}$ This report which is an almost word for word reproduction of the discussion between Sir Robert Hamilton, Sir Charles Gavan Duffy and myself was prepared in order that it might be laid before Lord Carnarvon, $\&$ it was sent by Sir Robert to Lord Carnarvon the evening of the Ist inst. Lord Carnarvon was at that time in London. ${ }^{212}$ The fact of our conversation having been reduced promptly to writing and forwarded to the Lord Lieutenant who is also a Cabinet Minister is significant.

Parnell on last evening made a very broad \& statesmanlike speech in Parliament on the second reading of the Irish Land Purchase Bill. ${ }^{2{ }^{23}}$ It was extremely moderate and was plainly intended to help on the working of the Purchase Scheme. Davitt ${ }^{214}$ has for the last couple

\footnotetext{
${ }^{211}$ See Document II.

${ }^{212}$ Where he was secretly meeting with Parnell at ${ }^{5} 5$ Hill Street, Mayfair: L.P. Curtis, Coercion and Conciliation in Ireland, I880-92: a study in Conservative Unionism (Princeton, NJ, I963), pp. 49-54.

${ }^{213}$ See Hansard, CCG, cols II03-1108.

${ }^{214}$ Michael Davitt (I846-I906), chief arms purchaser for the IRB, imprisoned on a charge of incitement to murder (1870-1877), instrumental in the foundation of the Land League of
} 
of weeks been unsparing in his denunciation of the bill as a mere measure of relief for Irish landlords. Parnell's speech therefore means war between himself \& Davitt \& in such a contest I shall back Parnell to win all along the line.

I saw Harrington MP today at the rooms of the National League \& had a long talk with him about the political situation. I told him that the Solicitor General for Ireland (John Monroe $)^{25}$ had mentioned to me that boycotting was beginning to be very troublesome in the south of Ireland, \& I impressed upon Harrington the importance of curbing so dangerous a propensity. He told me that the most troublesome County in Ireland at present is Wexford \& that in that County men who, when agitation involved personal risk had slunk away, were now endeavouring to earn a cheap popularity by encouraging, if not outrage, at least a violation of the law by boycotting, holding of Land League Courts \&c., and that he, Harrington, was so profoundly impressed with the danger of such disorders spreading that he had written to Parnell saying he would resign his post as Organiser \& Secretary of the National League, \& that in consequence of the representation made by him (Harrington) to Parnell, the latter had made his moderating speech on the Land Purchase Bill.

He said that when Parliament should have risen Parnell would come over to Ireland to exercise his personal influence in repressing not alone outrage, but all violation of the law.

\section{Augt.}

I saw Reed, ${ }^{216}$ the Divisional Magistrate, today. He is stationed at Athlone but his duties recently have called him down to Clare. He says that Clare is greatly disturbed \& that outrages of an aggravated character have recently increased in that County \& he fears there will be a disturbed winter in that part of the Country. ${ }^{217}$

\section{Augt}

I saw Edmund Dwyer Gray MP today at the Freeman Office. He told me what is the accepted version among Parliamentary men in

Mayo and the Irish National Land League (1879), Nat. MP for Cork North-East (I893) and for Mayo South (1895-1899).

${ }^{215}$ John Monroe (1839-1899), Solicitor-General for Ireland (1885), justice of the Landed Estate Court, Ireland (1885-1895).

${ }^{216}$ Andrew Reed (1837-I9I4), Sub-Inspector of the Irish Constabulary (1860), private secretary to the Inspector-General (I868-I879), CI of Donegal (I879-I88I), head of Crime Division (I88I-I884), Assistant IG (I882), DM for Western Division (I884-I885), IG of RIC (I885-I900).

${ }^{217}$ See MCRs (W), for July and August I885: CSO RPs I885/I6982, I6945. 
London as to the scandal which has overwhelmed Sir Charles Dilke. It appears that Dilke has for some time past been unduly intimate with Mrs. Donald Crawford whose husband ${ }^{218}$ was Secretary to the Lord Advocate for Scotland under Gladstone's Government. ${ }^{219}$ This Mrs. Crawford is sister to the widow of the late Ashton Dilke, ${ }^{220}$ the brother of Sir Charles.

The liaison was, it is said, discovered owing to Mrs. Crawford having recently gone home with Sir Charles Dilke for the indulgence of their illicit intercourse, \& having when in his bedroom perceived that another woman, also his lover, was there, a revelation which gave Mrs. Crawford such a shock that she rushed from the house, drove home to her husband's house, fell into a violent fit of hysterics \& then confessed all. The injured husband has instituted proceedings for a divorce and Sir Charles Dilke is for the moment at all events shunned by all his associates in the House of Commons. He has broken down in health under the strain \& it is openly stated by the Pall Mall Gazette that he will retire altogether from public life. ${ }^{221} \mathrm{It}$ is some confirmation of my view as to Chamberlain's pluck to find that while all other friends seem for the moment to have deserted Sir Charles Dilke, he, Chamberlain, has stuck to him, has had him down at his home near Birmingham to recruit his health, \& when Dilke a few days since reappeared for an hour or so in the House of Commons, Chamberlain in the most marked manner was friendly \& cordial with him while the rest of his associates slunk away from him.

Dilke \& Chamberlain have abandoned their intended visit to Ireland..$^{222}$

Gray mentioned that Chamberlain had been very badly treated by some members of the Irish party. I asked in what way had he been badly treated. Gray replied that before Chamberlain wrote the article for the Fortnightly Review he had been assured that if he made a pronouncement on those lines he should have the support of the Irish party, \& that now he finds that their support is given not to him but

\footnotetext{
${ }^{218}$ Donald Crawford (I837-I9I9), legal secretary to the Lord Advocate (I880-I885), Commissioner for Parliamentary Boundaries (1885), Lib. MP for Lanarkshire N.E. Division (1885-I895); he married Virginia Smith in I88I.

${ }^{219}$ John Blair Balfour (1837-1905), first Baron Kinross (1902), Lib. MP for Clackmannan and Kinross (I880-I899), Lord Advocate (I88I-I885, I886, I892-I895).

${ }^{220}$ Ashton Dilke (1850-1883), Lib. MP for Newcastle upon Tyne (1880-I883), editor of the Weekly Dispatch; he was survived by his widow, Margaret Mary (née Smith).

${ }^{221}$ See 'The break-up of the Liberal Party', $P M G, 3$ August I885, p. I. For the Crawford divorce, see Roy Jenkins, Sir Charles Dilke: a Victorian tragedy (London, I958), pp. 215-370.

${ }^{222}$ Their plan to visit Ireland was sabotaged by Parnell, who instigated a nationalist press campaign against them, and the withdrawal of offers of hospitality from the Catholic hierarchy: F.S.L. Lyons, Charles Stewart Parnell (London, I977), pp. 288-29o.
} 
to the Tories. This tallies with what Chamberlain himself told me in London.

II Sep.

I have not written any notes for over a month during about one half of which time I was absent on vacation. The campaign of the General election will soon open and it will be interesting to watch the effect of the events which have occurred during the past few months.

Parliament rose about the I ith of August. The Land Purchase Bill \& the Labourers (Ireland) Bill, 1885 \& also the Endowed Schools Bill passed into law. ${ }^{223}$ The Land Purchase Bill authorises the Land Commission to advance the entire purchase money to Irish Tenants purchasing their holdings, the advance being repayable by instalments at the rate of $\delta 4$ per cent during 49 years. The Labourers Act I885 extends \& simplifies the operation of the Labourers Act of I883 - the Endowed Schools Act establishes a Commission to control \& divide for the benefit of all denominations in Ireland the endowment for intermediate education hitherto exclusively enjoyed by Protestants. These Acts represent a substantial gain for the Irish people. ${ }^{224}$

The Tory Government still holds its popularity in Ireland \& the English Liberals are visibly nettled at such a result.

On Parnell's return to Ireland he made two important speeches, the first of which was delivered by him at Arklow about the middle of August. In this he spoke of the difficulties which Irish manufacturers have [to] contend with owing to the English manufacturers being so well equipped that they are able always to undersell the manufacturer till they break him, \& then they recoup themselves by raising their prices. He declared that in his opinion it was necessary for the success of Irish manufactures that the Irish people should be able to impose protective duties for a time at least.

His next speech was delivered at a dinner given to him at the Imperial Hotel, Dublin by the members of the Irish Parliamentary Party. This was about the 25th August. ${ }^{225}$ In this speech he said that

\footnotetext{
${ }^{223}$ Bill to amend Labourers (Ireland) Act, I883, and for other purposes connected with Labourers' Dwellings in Ireland: $P P$ I884-5, II, I87. Bill to Re-organise Educational Endowments of Ireland: $P P$ I884-5, I, 445. Parliament was prorogued on I4 August.

${ }^{224}$ Purchase of Land (Ireland) Act, I885 (48 \& 49 Vic., c. 73); Labourers (Ireland) Act, I 883 (46 \& 47 Vic., c. 6o); Labourers (Ireland) Act, I885 (48 \& 49 Vic., c. 77); and Educational Endowments (Ireland) Act, 1885 ( 48 \& 49 Vic., c. 78 ), which diverted $f_{1}$ I 40 , ooo of endowment funds to Catholic schools and colleges.

${ }^{225}$ Parnell spoke at Arklow on 20 August and at Dublin on 24 August: The Times, 22 August I885, p. 6; 25 August I885, p. 4.
} 
hitherto the Irish party had purposely abstained from pushing in Parliament directly the question of self government for Ireland but still that this course of action had been dictated by a resolve to impress upon England the necessity of granting Self Government to Ireland \& that their efforts had not been unsuccessful, but that in this next session of Parliament the efforts of the party would be concentrated upon a determined effort to win for Ireland a freedom fully as great as she enjoyed under Grattan's Parliament but without a House of Lords.

On the following day the Irish Parliamentary Party held a meeting at which they passed resolutions declaring that the best way of selecting candidates for Irish constituencies would be by holding County Conventions to decide on the selection, \& that Mr. Parnell \& the Irish Party were entitled to be taken into consultation in reference to such selections. ${ }^{226}$

The members then agreed to take the following pledge individually \& collectively and recommended that no Irish constituency should elect any candidate who would refuse in writing to bind himself by the same pledge. The pledge was to the following effect -

"I promise to sit, act, and vote with the Irish party led by Mr. Parnell and in the event of a majority of the party convened by notice for the purpose deciding that I have violated the pledge I undertake to resign my seat., ${ }^{{ }_{227}}$

Meanwhile, Mr. Chamberlain had made, or else made a few days after Parnell's pronouncement, a strong radical speech in which he confined himself to English affairs but sketched out for England a very advanced radical programme. ${ }^{228}$

A few days afterwards Lord Hartington at Waterfoot made a Whig speech in which he plainly dissented from Chamberlain's policy $\&$ as regards Ireland, he alluded to Parnell's speech \& said that Parnell's policy of wringing from Parliament freedom for Ireland was impossible. ${ }^{229}$

Parnell was a few nights afterward entertained at a dinner by the Lord Mayor at the Mansion House and in his speech there he alluded to Lord Hartington's statement somewhat in the following terms "There are politicians in England who tell us that to win freedom for Ireland is impossible. It may be that they are right, but if we are

\footnotetext{
${ }^{226}$ The meeting took place at the offices of the Irish National League in Sackville St, Dublin, on 25 August I885: The Times, 26 August I885, p. 7.

${ }^{227}$ See Lawrence W. MacBride, The Greening of Dublin Castle: the transformation of bureaucratic and judicial personnel in Ireland, I892-1922 (Washington, DC, I99I), pp. 46-47.

${ }^{228}$ Chamberlain spoke at Hull on 5 August i885: The Times, 6 August I885, p. 6.

${ }^{229}$ Hartington spoke on 29 August i885: The Times, 3i August i885, p. 8.
} 
prevented from obtaining freedom for Ireland we can at least make all things impossible for those who seek to prevent us."

This sentiment was received with rapturous applause. Parnell then alluded to the rumours of some outrages having recently taken place in Kerry \& he very emphatically \& earnestly exhorted the Irish tenants to abstain from all outrage \& he warned the Irish landlords to be moderate in their demand for rent as this season was a very bad one. ${ }^{230}$

On the 8 September 1885 Chamberlain attended a meeting at Warrington \& made a big speech in which he stuck to his guns as regards to the radical programme. ${ }^{231}$

Lord Randolph Churchill early in September 1885 made a speech at Sheffield in which he confined himself to lauding the success of his Government in putting foreign affairs to rights \& his only allusion to Ireland was a short one defending the Government for having allowed the Crimes Act to lapse. He did not mention Parnell's name. ${ }^{232}$

On the 8th Sep I885 Chamberlain spoke at Warrington. He reiterated the radical programme \& he then launched out into a discussion of Parnell's speeches. He said in effect that there was an alliance between Parnell \& the Tories \& he used the following words, "Well now what is Mr. Parnell's programme. He says that in his opinion the time has come to abandon altogether attempts to obtain remedial measures or subsidiary reforms and to concentrate the efforts of the Irish representatives upon the securing of a separate and independent Parliament which is to consist of a single chamber and whose first object it is to be to put a protection duty against all English manufacturers. Then he says in the second place that he expects Whig \& Tory will vie with one another in helping him to a settlement on his own terms; and he says in the last place that if any party seeks to make this object impossible that he and his party will make all things impossible for them. Well, gentlemen, I am not a Whig and I certainly am not a Tory but speaking for myself I say that if these and these alone are the terms on which Mr. Parnell's support is to be obtained I will not enter into the compact."

I think it well to keep a copy of all the portions of Chamberlain's speech which relate to Ireland \& therefore I have taken the following cutting from the Freeman's fournal. ${ }^{233}$

\footnotetext{
${ }^{230}$ 'Moonlight' raids were carried out in north Kerry on 18 and 27 August, and Parnell delivered his speech on I September: The Times, 28 August I885, p. 4; 2 September I885, p. 6.

${ }^{231}$ See The Times, 9 September i885, p. 6.

${ }^{232}$ Churchill spoke on 4 September 1885 : The Times, 5 September 1885, p. 6.

${ }^{233}$ Cutting inserted into journal: see FF, 9 September I885, p. 4 .
} 
The commentaries of both the Freeman's fournal \& of almost all shades of the English press on this speech are to the effect that Mr. Chamberlain has pledged himself against any separate legislature for Ireland, but I think that he has been far too astute to do anything of the kind. He has pledged himself against allowing an Irish legislature to impose a protection tariff against English goods, but this is the extent of his pledge as I read the speech.

Dr. Walsh, the new Archbishop of Dublin, entered Dublin about a week ago. He met with a very enthusiastic reception from the people but the absence of the richer class of Catholics was most marked. In reply to an address presented to the Archbishop on his arrival he emphatically stated his opinion that peace \& content could never reign in Ireland until she had won a separate legislature. ${ }^{234}$

This is, I believe, the first instance in History on which a Roman Catholic Archbishop of Dublin openly expressed himself in favour of an Irish Parliament. Dr. Walsh's declaration renders it certain that the Irish Bishops to a man may now be counted among Mr. Parnell's followers. I doubt if the same could at any time after 1829 have been said of O'Connell.

Charles Russell QC MP came to Dublin a couple of days ago. I had a long chat with him today. He told me that he met Dr. McEvilly, ${ }^{235}$ the Roman Catholic Archbishop of Tuam, on the day before yesterday $\&$ that the latter told him there was considerable political apathy in the West of Ireland \& that he accounted for it by the fact that the farmers believe they have got from politics nearly all the personal benefit they are likely to receive, \& that they object to the prospect of men of a low social position being almost the only candidates for parliamentary honours owing to the imposition of the 'pledge' formulated by Parnell; the ground for that objection is not however their dislike of being represented by men of a comparatively low social position, but is their belief that they, the farmers, will be called upon to contribute to the support of members who have not means of their own to support them.

\footnotetext{
${ }^{234}$ Walsh spoke on his arrival at Kingstown and in reply to an address from the Corporation of Dublin at Westland-row station on 4 September i885: The Times, 5 September I885, p. 7; Patrick J. Walsh, William f. Walsh, Archbishop of Dublin (Dublin, 1928), pp. I79-18I.

${ }^{235} \mathrm{John}$ MacEvilly (I8I6-I902), Archbishop of Tuam (I88I-I902), a powerful advocate of tenant right and home rule.
} 
This may be true. I doubt its accuracy \& I venture to predict that west of the Shannon there will not be a candidate returned who will not take the Parnell pledge.

I8 Sep.

Mr. Chamberlain has made another speech. His audience on this occasion being the Liberals of Glasgow. ${ }^{236}$ His language regarding Ireland \& Mr. Parnell's demands was much more conciliatory than were his utterances at Warrington.

John Morley MP made a speech at Hackney on the $16^{\text {th }}$ inst in support of Charles Russell's candidature. ${ }^{237}$ It was a manly, outspoken speech. Regarding Ireland he said "there was not anything very terrible and shocking in Mr. Parnell's views about a protective tariff for Ireland - at least it ought not to be to a Tory Government who had appointed a Commission to elicit opinion in favour of a protective tariff for England. Of course, the Liberal party could give no countenance to such questions and would do their best to persuade the Irish people that they would be doing themselves a great mischief if they resorted to such a course, but there were other demands which Mr. Parnell had made \& they should go to meet these views \&." Short of separation, he would go as far as he could and he hoped his party would go as far as they could to meet the views of the Irish nation, as soon as they were quite sure what the views of the Irish nation were. "In my opinion no solution would be adequate which did not recognize \& attract to itself the indestructible national sentiment of the Irish people".

I dined on the ${ } 5^{\text {th }}$ inst. with Fr. Thomas Finlay SJ, ${ }^{23^{23}}$ the Rector of Belvedere College Dublin, to meet the Archbishop. Our party included the Archbishop, the Provincial of the Jesuits, several priests of the order \& the following MPs, Wm. O'Brien, E. Dwyer Gray, T. Harrington \& C. Dawson. Besides Wm. O'Brien was Sir Thomas Grattan Esmonde Bart., ${ }^{239}$ a young man of about 22 years of age who, as Fr. Finlay told me, is a very strong Parnellite. I asked Fr. Finlay was Sir Thomas's Parnellism acquired with a view to securing a seat in Parliament. He said no, that the young man had become an Irish Nationalist from sincere conviction.

\footnotetext{
${ }^{236}$ Chamberlain addressed the Glasgow Liberal Association on I5 September 1885: The Times, I6 September I885, p. 7 .

${ }^{237}$ Morley spoke at Clapton on I6 September I885: The Times, I7 September I885, p. 4.

${ }^{238}$ Thomas Aloysius Finlay (I848-I940), Rector of Belvedere College, Dublin (I882-I887), professor of philosophy and political economy, Royal University of Ireland (I883-I930).

${ }^{239}$ Sir Thomas Henry Grattan Esmonde (1862-1935), Nat. MP for Dublin South (18851892), later a senator of the Irish Free State and Chairman of the National Bank.
} 
I spoke to O'Brien after dinner. He seemed struck with young Esmonde \& said that if Esmonde asked him his opinion he would counsel him to remain out of Parliament because he perhaps did not know how painful a position he might be taking up by entering Parliament as an Irish Nationalist, but that if Esmonde was determined on his course he thought that he would make a good candidate for the dangerous division of Dublin City.

I8 Sep.

Mr. Gladstone has broken silence by issuing a manifesto of 6 columns in length, in which he proclaims that he is ready to lead his party at the General election. The manifesto is published in this evening's papers $\&$ it deals with every branch of politics both domestic \& foreign. ${ }^{24^{\circ}}$ His allusions to Ireland occupy about a column. The principal sentence in the Irish portion runs as follows,

"In my opinion not now for the first time delivered the line is clear within which any desires of Ireland constitutionally ascertained may, $\&$ beyond which they cannot, receive the assent of Parliament. To maintain the supremacy of the Crown, the unity of the Empire and all the authority of Parliament necessary for the conservation of that unity is the first duty of every representative of the people, but subject to the governing principle every grant to portions of the Country of enlarged powers for the management of their own affairs is in my view not a source of danger but a means of averting it and is in the nature of a new guarantee for increased cohesion, happiness and strength. I believe that history \& posterity will consign to disgrace the name and memory of every man be he whom he may and on whichever side of the Channel he may dwell that having the power to aid in an equitable settlement between Great Britain and Ireland shall use that power not to aid but to prevent or retard it."

I wrote a couple of days ago to Sir Rowland Blennerhassett, sending him the two articles of Sir C. Gavan Duffy which have already appeared on the subject of 'Colonial Constitutions' ${ }^{2_{24}}$ and asking him (Sir Rowland) to write an article or two in a similar style on the subject of the constitution of Bavaria, shewing the degree of dependence and of independence which that Country enjoys in relation to the German Empire.

\footnotetext{
${ }^{24^{\circ}}$ See The Times, i9 September i885, p. 8.

${ }^{241}$ For Duffy's proposals for an Irish parliament, see 'Appeal to the Conservative Party', National Review, 4 (February I885), pp. I42-I44.
} 
24 Sep.

On yesterday I received a letter from Sir Robert Hamilton's private secretary saying that the Lord Lieutenant (Lord Carnarvon) would be glad to see me today at the Viceregal Lodge. I went out and saw him and we had a long conversation on the present state of affairs in Ireland. ${ }^{2{ }^{2}}$ His Excellency asked me could I give him any information as to the ability or inability of the tenants to pay their rents this winter and as to the course which the landlords would take in reference to such rents. I replied that I believed the Irish tenant was not dishonest, that he would pay his rent if he could do so, firstly because he was well disposed to pay his rent if he could pay \& next because he had a mortal dread of law costs. Lord Carnarvon said he shared this opinion. I then remarked that as far as I could learn the majority of Irish tenants this year would not be able out of the year's harvest to pay their rents in full, and that if the landlords as a body pressed for the full rents $\&$ proceeded to evict in the case of non-payment there would be an organised resistance on the part of the tenants, which I feared would lead to very bad work. He said he also shared this opinion. He asked me to get him any information I could quietly obtain on these points \& I promised to do so. He then discussed the question of Home Rule. I told him that I was a determined nationalist \& that I was so because I believed that it was hopeless to expect peace until the people began to feel responsibility all round, \& that they would never feel this until they became aware that practical effect would be given to the doctrines which they might support with their voices \& votes. Lord Carnarvon said "the great difficulty is of course the Land Question, no English party can consent to abolish all safeguards for landlords' property". I replied that I should be sorry to see Irish landlords left without safeguards. Lord C., "what then would you do to give safeguards." I replied that I thought the plan suggested by Sir C. Gavan Duffy in his conversation with Sir R. Hamilton \& myself would answer, viz. to have two chambers. One containing say Ioo members of whom each of the 32 Counties should return 3, each voter being entitled to vote only for 2 \& each voter being if so minded allowed to give his 2 votes for one candidate. This would give to property a representation of $1 / 3$ at the start. The second chamber or Senate to consist of say 6o members, all in the first instance nominated by the Crown so as to fairly represent all different interests, \& of this Senate a certain proportion, say ${ }^{\mathrm{I}} / 3$, to be recruited every 5 years by election by County Boards on some restricted franchise. Furthermore, I said give a guarantee by inserting

\footnotetext{
${ }^{242}$ See Document $\mathbf{4}$ and Alan O'Day, Parnell and the First Home Rule Episode (Dublin, I986), p. 97.
} 
in the Constitution a provision that compulsory expropriation should never be resorted to.

Lord C., "that is very good so far as it goes, but how would you prevent the landlords being ruined by a tax being put on their property of such an oppressive nature as virtually to deprive them of their property." I replied that it was hard off-hand to devise a safeguard of absolute demonstrable efficacy but that I believed there was a large element of latent conservatism in Ireland which I believed would come into play when we had an Irish responsible Parliament.

Lord Carnarvon, "well, probably you are correct."

\section{Sep.}

I saw Sir Robert Hamilton today \& I asked him how stood the Crime Statistics. He said that the record of outrage was not increasing but that boycotting was in many places prevalent, ${ }^{243} \&$ he observed that United Ireland most injudiciously had for weeks past been setting forth a string of reports from local branches of the National League detailing most circumstantially the particulars of boycotting, \& that it was from United Ireland that the Standard had culled its couple of columns of Irish intelligence on which that paper based its demand for renewed coercion for Ireland. ${ }^{244}$ I said I would do my best to put a stop both to boycotting \& to the reports of it by speaking to the prominent nationalist members.

I called on T. Harrington MP at the National League rooms \& I spoke to him on the subject of boycotting \& of the reports thereof. I found him fully as strong as myself in his condemnation of the folly of the League branches in allowing boycotting \& in the sub editor of United Ireland ${ }^{245}$ in publishing the reports. He told me he had already written peremptorily to some of the branches demanding the expulsion of their Secretaries for aiding and abetting in unjustifiable boycotting proceedings, \& that if his demand was not complied with he would get the offending branches cut off entirely from the League. $\mathrm{He}$ also promised to write to William O'Brien MP, the Editor of United Ireland, calling his attention to the importance of omitting the boycotting reports.

\footnotetext{
${ }^{243}$ Between June and September I885, the number of persons boycotted in Ireland increased fourfold to 885: Stephen Ball, 'Policing the Land War: official responses to political protest and agrarian crime in Ireland, 1879-9I' (unpublished $\mathrm{PhD}$ thesis, University of London, 2000), p. 255.

${ }^{244}$ See United Ireland, I9 September I885, p. 3, and 26 September I885, p. 2; Standard, 24 September I885, p. 4. For Carnarvon's response to the latter article, see Carnavon to Hicks Beach, 25 September i885: CP Add MS 60825, fo. 9 I.

${ }^{245}$ James O'Connor (I836-I9IO), journalist and long-time member of the IRB, sub-editor of United Ireland (I88I-I890), Nat. MP for Wicklow West (I892-I9I0).
} 
3 Oct.

United Ireland of this week is admirable in tone. It discounternances boycotting in a succession of short articles very well written \& I observe that in the branch reports there is no mention of boycotting save to condemn it.

5 Oct.

A few days ago a long letter appeared in the Irish papers addressed by Mr. John Ferguson ${ }^{246}$ of Glasgow to Mr. Chamberlain. The letter was an appeal in Ferguson's bombastic style to 'Joe Chamberlain' to side with Parnell in his demand for a separate Parliament in Ireland. ${ }^{247} \mathrm{~A}$ couple of days afterwards Chamberlain's answer appeared \& it was as follows -

"To John Ferguson Esq.

"Highbury Moor, Birmingham September 21, I885

"DEAR SIR - I have only time to acknowledge briefly your letter of the $I^{\text {th }}$ inst. as regards the Irish question. You will do me the justice to acknowledge that in writing to you some time ago, and before any idea had got abroad of Mr. Parnell's recent manifesto, I stated that I was conscientiously opposed to a separate Parliament for Ireland, believing as I did, and do, that it would be absolutely ruinous to the best interests of Ireland, as well as dangerous to the security of England. I hope you will carefully consider the terms in which I made my statement at Warrington, and that you will see that they are full of sympathy for Irish grievances and respect for Irish leaders; but I cannot alter my conviction upon the main point. - I am yours truly,

\section{J. CHAMBERLAIN" ${ }^{\prime 2}{ }^{8}$}

I was very sorry to see this letter of Chamberlain's \& I wrote to tell him so \& to tell him, furthermore, that from close observation of public opinion in Ireland I had become satisfied that during the past couple of months the idea of a separate legislature for Ireland with full legislative power in Ireland, save as regards control of the forces military \& militia \& save as to the imposition of a tariff, had made surprising progress even among the richer people in Ireland,

\footnotetext{
${ }^{246}$ John Ferguson (1836-I9o6), Irish nationalist and co-founder of the Scottish Labour Party (I888).

${ }^{247}$ See $F \mathcal{F}$, 18 September i885, p. 6.

${ }^{248}$ See The Times, 29 September i885, p. 6.
} 
\& I earnestly asked him not to pledge himself publicly against such a legislature. ${ }^{249}$

He wrote me a friendly letter asking me whenever I should be in London to call on him to discuss Irish affairs with him, but adding that nothing could in his opinion alter his view that a separate parliament would [not] at present be desirable or possible, that he hoped the 'National Council' referred to in the Fortnightly Review article would in course of time acquire very important powers, but that he was himself surprised at the vehemence of the English feeling against further concessions to Ireland, \& that he believed it would be probably more easy to arouse a strong anti-Irish feeling throughout England than to carry at present a measure even so advanced as that sketched in the Fortnightly Review article. ${ }^{250}$

I9 Oct.

A few days ago a speech was made in Pontefract by the Right Honble Mr. Childers, the Ex Chancellor of the Exchequer, in which he formulated a detailed scheme of Home Rule for Ireland. ${ }^{251} \mathrm{He}$ declared that the Imperial Parliament should have control of foreign affairs, Customs, Post Office \& the army \& navy but as for anything else it could be left to the national assemblies of Ireland \& of Scotland, if it were deemed desirable to set up such an assembly for Scotland.

John Dillon spent yesterday with me \& we discussed the present position \& prospects of politics in Ireland. I was amused at hearing from him that when he \& Parnell were in the train a few days ago on their way to the Cork Convention, ${ }^{252}$ Parnell read Childers' speech \& turning round to Dillon said to him without a smile "I really think that after all we shall find that we ought to deal with the Liberals. I fear that the Tories will not be able to do for us all we want".

Parnell is certainly a thorough politician. He cajoled Chamberlain into publishing the Fortnightly Review article - he then turned over to the Tories so as to get them well into his net, \& now he is quite ready to join the Liberals in dishing the Tories.

I asked John Dillon had Parnell made up his mind whether it would be better to have a Parliament in Dublin and at the same time send members to the Imperial Parliament or whether it would be preferable

\footnotetext{
${ }^{249}$ See Document 16.

${ }^{250}$ See Document 17.

${ }^{251}$ Childers spoke on I2 October I885: The Times, I3 October I885, p. I2.

${ }^{252}$ The convention, held on 12 October 1885 , was the most significant county assembly to be held prior to the general election: The Times, i3 October 1885, p. 6; Ff, i3 October I885, p. 5 .
} 
to have only the Irish Parliament \& for Ireland to have no share in the Imperial Parliament.

Dillon said that he believed Parnell had not made his mind up on the point, that Parnell's theory was to get whatever he could get most easily, that he had no bigoted view in favour of one plan as against the other.

John Dillon's own view is that we must continue to send members to the Imperial Parliament. I asked him did he expect that members of popular politics could be maintained in the Imperial Parliament after Home Rule had been obtained, because it would not be then likely that popular enthusiasm in Ireland would continue at fever heat, \& without great popular enthusiasm it would be certain that rich men able to support themselves in London would be sure to monopolise the representation of Ireland in the Imperial Parliament. His opinion is that within a very few years, probably 5 years, the Radical party in England will have carried a measure for paying all members of Parliament.

I got a letter from Sir Robert Hamilton asking me to call to the Castle to see him. I went up \& found that Sir Robert had been reading an article in the Nineteenth Century of November I882 by John Morley entitled "Irish Revolution and English Liberals". The article was one for which I remember I furnished most of the materials to Morley. ${ }^{253}$

In reference to this note, Sir Robert asked me to find out does Davitt still approve of the Constitution sketched in it \& can he give me a copy of the speech referred to in the note. ${ }^{254}$

The fact of Sir Robert Hamilton asking me to get this information tends to shew that the Government are really considering the question of what form of Home Rule can be granted at once.

I said that all parties were agreed that there should be two chambers. Sir R. said, "no, Parnell is opposed to a second chamber". I said not at all - he is opposed to a House of Peers but not to a Senate.

I have been looking over some pages of this diary and I find in them an account of an interview which I had on the 28 May at the Castle with Sir Robert Hamilton \& John Morley, at which Sir Robert astounded

\footnotetext{
${ }^{253}$ John Morley, 'Irish revolution and English liberalism', Nineteenth Century, I2 (November I882), pp. 647-666. Hamilton directed Fottrell to a passage in the article that considered Michael Davitt's views on the subject and advocated a constitution for Ireland based on the Canadian model.

${ }^{254}$ Davitt spoke at the New York Academy of Music on I9 June I882: Irish World, I July I882.
} 
me by telling me that the Legal Adviser of the Castle had advised the Lord Spencer that the Conspiracy Act of I875 did not apply to Ireland.

It is a curious commentary on this statement that I have now to mention I was with Sir Robert at the Castle about Io days ago and we [were] discussing the question of boycotting \& Sir Robert pulled out of his private dispatch box a print of the confidential instructions issued by him to Reed, the new Inspector General of Constabulary, on the occasion of his taking office about a month ago. ${ }^{255}$ In these instructions Reed's attention is specially called to the provision of the Conspiracy Act of 1875 \& he is told that this Act gives ample powers for dealing with boycotting and, as a matter of fact, it is under this Act that the boycotting prosecutions now taking place in Ireland have been instituted. ${ }^{25^{6}}$

\section{Oct.}

I was not able to see Davitt until today as he had been absent on a lecturing tour in Scotland. ${ }^{257} \mathrm{He}$ returned this morning and I saw him at the Imperial Hotel. ${ }^{25^{8}}$ I told him I had been reading Morley's article in which the allusion was made to the speech which he (Davitt) had delivered in New York in 1882 in which he had advocated the establishment of two chambers in Ireland, and I asked him was he of the same opinion still.

Davitt - Not at all, I have quite changed my opinion. When I spoke in New York I thought that the Irish landlords would shew some sense \& would settle with the tenants on reasonable terms for the sale of their holdings, but I have since seen that it is hopeless to expect any common sense or any justice from the Irish landlords and therefore I shall be no party to bringing about a scheme which would establish, in the shape of a second chamber, a landlord anti-Irish \& pro-British assembly which would strive to thwart the Irish chamber of representatives at every step.

\footnotetext{
${ }^{255}$ See Hamilton to Reed, 30 September i885: CSO RP I885/17947.

${ }^{25}{ }^{5}$ Between August and December 1885, 425 persons were prosecuted under this act: 'Summary of cases in which boycotting and intimidation have been prosecuted under the ordinary law from the expiration of Prevention of Crime Act 1882 to 3 Ist December 1885': CSO, RP $1888 / 26523$.

${ }^{257}$ Between 25 October and 8 November 1885, Davitt delivered lectures at Glasgow, Greenock, Aberdeen, Edinburgh, Dundee, Inverness, and Coatbridge: 'Land nationalization; or, national peasant proprietary', in Carla King (ed.), Michael Davitt: collected writings, I868-1906, I (Bristol, 200I).

${ }^{25^{8}}$ Situated in Sackville (O'Connell) Street, Dublin, it was destroyed during the Easter Rising of 1916.
} 
GF - I am sorry to hear that you are opposed to a second chamber. I for one regard it as inevitable \& as eminently desirable. I should be sorry to see a second chamber set up composed of such elements as would make it likely that they would persistently thwart the action of the lower chamber, but I can see enormous advantages in the establishment of a second chamber which would, for example, by its veto postpone for a year the consideration of a measure which the lower chamber might have adopted in a gust of passion. Of course the Senate or second chamber would have to be so composed as fairly to represent all interests.

Davitt - Your view is an intelligible one. I am a social democrat \& therefore I am opposed to the establishment of a second chamber which I believe will mainly represent landlords and capitalists, you are in favour of a second chamber because you are an Irish national conservative.

GF - I admit I am in many respects a conservative.

Davitt - So is Parnell, \& if the Irish landlords had any sense they would see that in an Irish Parliament Parnell must be a conservative leader. He is no revolutionist. He was originally a conservative - events have thrown upon him the task of rousing the nation \& at present short sighted people regard him as a revolutionary force. He is eminently constitutional \& in an Irish Parliament he must be a conservative most of his Parliamentary companions will side with him [-] there will be in Ireland a strong conservative party \& my party, viz. that of social democrats will be in a hopeless minority for many years to come.

I have from time to time met some landlords to whom I have opined this view, \& they have said that if they were certain that Parnell was not aiming at total separation from England they would throw in their lot with him. You know I am in favour of total separation but I recognise its impossibility, \& recognising it I for one would give a fair trial even to Chamberlain's Fortnightly Review scheme of Irish government.

GF. We shall get more than Chamberlain's scheme, but we cannot expect that English statesmen would consent to grant autonomy to Ireland without providing safeguards against the confiscation of property of any class in Ireland, \& therefore I consider that the second chamber is inevitable.

Davitt - No - it will be much easier to get a scheme carried for a single chamber than for two chambers. Parnell is opposed to the scheme of two chambers.

GF - No, I do not believe he is. He is pledged against a House of Peers but not against a Senate.

Davitt - I have the best reason for believing that Gladstone is quite prepared to concede at once an Irish legislature. He wants only to 
know what is Parnell's minimum. The Liberals are going to win at the General election by an overwhelming majority \& Parnell will make a huge mistake if he asks the Irish voters in England to vote for the Tories. In the first place he will not succeed in inducing them to do so, and in the next place even if he did succeed he would be allying himself with a losing party.

GF. Anyway, he seems to have acted judiciously up to the present. He has left the Liberals to expect that he will throw in his lot with the Tories \& he has thereby forced the Liberals to make a bid for his support, as witness Childers' speech.

After I had spoken to Davitt I went to the Castle to see Sir Robert Hamilton \& I told him in general terms Davitt's opinion. ${ }^{259}$

Sir Robert. I am sorry to hear that he is opposed to a second chamber. I regard it as essential.

GF. So do I, I regard it as inevitable \& also as eminently desirable.

Sir Robert. I shall now read for you a document which I have just roughly finished \& which I must ask you to regard as absolutely confidential. No one save myself has yet seen it \& I have not spoken of it to anyone save yourself.

Sir Robert then read for me a voluminous report which he has drawn up for the Lord Lieutenant to be laid before the Cabinet. It is a very able document \& it marks a wonderful advance in opinion on the part of Sir Robert Hamilton. Indeed it represents a complete reversal of some of his former opinions a reversal which I believe has been to a great extent brought about by the discussions which he \& I had with Sir Charles Gavan Duffy in last July. ${ }^{260}$

Sir Robert then read for me a second document which contained a scheme for the separation of the Exchequers of Great Britain \& Ireland.

It was impossible for me to commit to memory the exact figures given in this document but its argument was somewhat to the following effect -

(a) that the national debt of Great Britain \& Ireland should be divided between the two countries in the proportion at which the debts of the two countries respectively stood at the date of the Union (I80I).

(b) that for a certain period at all events the portion of the debt allocated to Ireland should be guaranteed by the Imperial Exchequer

\footnotetext{
${ }^{259}$ See Document 19.

${ }^{260}$ Fottrell outlined the main arguments of the report: see Document 20.
} 
\& that such Exchequer should also guarantee whatever money would have to be raised for buying out the Irish landlords.

(c) that the Imperial Exchequer should defray the cost of maintaining the Constabulary until that force should be disbanded.

(d) that Ireland should defray the cost of maintaining in Ireland I2,ooo troops, such cost would represent about $f_{1}, 300,000$ per annum, but that in order to avoid the unpleasantness \& irritation which the annual discussion of a vote for the purpose might entail, that instead of making this an annual charge there should be added to the Irish debt a bulk sum of $£ 40,000,000 \&$ that therefore the entire vote for the army should be by the Imperial Exchequer.

(e) the result of the foregoing arrangement would be to leave Ireland with a debt of about 88 millions - made up as follows,

$\begin{array}{ll}\text { proportion of National Debt - } & 37 \text { millions } \\ \text { added to cover the Army expenses - } & 40 \\ \text { outstanding Treasury loans in Ireland }- & \text { II } \\ \text { total }- & \text { 88 }\end{array}$

(f) the estimated annual sum now raised by Irish taxation is about $£ 7,800,000$, which the expenditure in Ireland out of the Imperial Exchequer is about $£ 700,000$ less per annum.

(g) that after allowing for the annual sum payable for interest on the debt of 86 million, the revenue of Ireland would under the foregoing arrangement shew a surplus of about $\mathcal{E}_{\mathrm{I}, 300,000}$ per annum.

It is certainly instructive to compare these official reports of Sir Robert Hamilton of the 28 October i885 with that which he told me of on the 27 June $1885 .{ }^{26 !}$ The intervening four months have produced a wondrous change.

\section{Dec.}

The General election is nearly over. It has been perhaps the most remarkable election of this century. At the last General election, viz. that of I880, the Liberal Party was returned to power with a majority of [54]. ${ }^{262}$ The election almost now concluded will leave the two English parties, Tory \& Liberal, neck \& neck. There will probably not be more than two votes difference between the members who may support the Tories \& those who may support the Liberals, but (and here comes the interest of the position) there are 86 Parnellites among the new

\footnotetext{
${ }^{261}$ See Document 9.

${ }^{262}$ In the general election of $\mathrm{I} 880$, the Liberals won 353 seats, the Conservatives 238, and the Irish Nationalists 6I.
} 
members, and into which scale will their votes be thrown? If into the Tory scale then the Tories will exactly number man for man the Liberals. If with the Liberals then the latter party will have a majority of about i72 over their opponents.

Parnell has managed either with consummate skill and foresight or with marvellous luck to place his party in the position of arbiters of the destiny of the two great parties in the state.

At the opening of the election he put forth a manifesto to the Irish electors in Great Britain calling down their vengeance on the Liberal party and asking the Irish electors in England \& Scotland to vote solid for the Tory candidates. ${ }^{263}$ The result of the manifesto was astounding. Even in places where there was a very strong local prejudice among the Irish voters in favour of the Liberal candidate they marched with the discipline of an army to vote for the Tory. All sides admit that about 25 seats (all or almost all in boroughs) were thereby transferred from the Liberals to the Tories. At first it seemed as if even in the counties the Tories were about to win, but after the first couple of days of County elections the Liberals in England, Scotland \& Wales drew steadily ahead \& they now bid fair to command 333 or even 335 seats out of 67o. The Parnellites number 86.

In Ireland, Parnell has as regards Leinster, Munster \& Connaught simply swept all before him. There is not in the entire of these three Provinces a single Liberal or Conservative member. In Ulster, the Parnellites offered to the Whigs there a compromise by which the latter might have won 3 or 4 seats in exchange for their support to the Parnellites in 3 or 4 other seats. But Lord Hartington came over to Belfast to a Liberal demonstration and his advice to the Ulster Liberals was to coalesce with the Ulster Tories against the Parnellites. ${ }^{264} \mathrm{He}$ must feel very satisfied now of the wisdom of his advice. The Liberals have been swept out of every single seat in Ulster, Munster, Leinster and Connaught. They have not a solitary representative in Ireland.

In Ulster, the Tories have won I6 seats \& the Parnellites have captured I7 so that even in the sturdy north the national Party has a majority in the representation.

There was intense interest felt in the results of the elections for West Belfast \& for the City of Derry. In the latter Justin McCarthy ${ }^{265}$ as a Nationalist opposed Lewis, the sitting member, a strong reactionary

\footnotetext{
${ }^{263}$ The manifesto was drawn up by Parnell on 2I November and subsequently issued by T.P. O'Connor: see The Nation, 28 November 1885, repr. Grenfell Morton (ed.), Home Rule and the Irish Question (London, I980), pp. 9I-92.

${ }^{264}$ Hartington addressed the Belfast Liberal Club and later spoke at the Ulster Hall on 5 November i885: The Times, 6 November I885, p. 6.

${ }^{265}$ Justin McCarthy (1830-1912), Nat. MP for Co. Longford (1879-1885) and for Londonderry city (I886-I892), chairman of the anti-Parnellite party (I890-I896).
} 
Conservative. The Presbyterian Liberals in the city were numerous enough to be an important factor in the election, and a bargain was struck between the Nationalists and them by which it was agreed that the Liberal Presbyterians should abstain from voting in the election for Derry City, and that in consideration of such abstention the Nationalist voters in North Derry should support Sam Walker, the late Liberal Attorney General, against his Tory opponent Mulholland. ${ }^{266}$ At the last moment the Liberal Presbyterians in Derry City broke their word $\&$ voted for Lewis. As a result, Justin McCarthy was beaten by 30 votes \& Derry City was lost to the National party. But if it was lost, its loss was promptly revenged for the nationalist voters in North Derry rallied with absolute unanimity around Mulholland \& defeated Walker by about 2 to $\mathrm{I}^{267}$

In West Belfast, Sexton was the National candidate. The Presbyterian Liberals acted in the same way in West Belfast as they did in Derry City \& Sexton was defeated in West Belfast. ${ }^{268}$ This double defeat \& as the nationalists believed, double treachery of the Liberals in the North cost the Liberal party dear. Dickson, Lea, ${ }^{269}$ Barbour, ${ }^{270}$ Walker, Shillington, ${ }^{271}$ Shaw Brown, ${ }^{272}$ Findlater, ${ }^{273}$ one and all have been defeated with great slaughter \& there are now in Ireland only two parties - the Irish Party numbering 85 Irish members \& I English member (T.P. O'Connor ${ }^{274}$ who was returned for Scotland Ward Division of Liverpool) - and the English party or Constitutional

\footnotetext{
${ }^{266}$ Henry Lyle Mulholland (1854-1931), second Baron Dunleith (1895), Con. MP for Londonderry North (1885-1895).

${ }^{267} \mathrm{McC}$ arthy polled 1792 votes and Lewis I824. At the election for Londonderry North (30 November I885), Mulholland defeated Samuel Walker by 5 I80 : 3017.

${ }^{268}$ At the election for Belfast West (26 November i885), James Horner Haslett (Con.) defeated Thomas Sexton by $3780: 3743$.

${ }^{269}$ Thomas Lea (I84-1-1902), Lib. MP for Donegal (I879-I885), Lib. U. MP for Londonderry South (I886-I900), lost the contest for Donegal East to Arthur O'Connor (Nat.) by $4089: 2992$.

${ }^{270}$ John Doherty Barbour, Lib. MP for Lisburn (1863) but unseated on petition, lost the contest for Antrim South to W.G. Ellison Macartney (Con.) by $5047: 3680$.

${ }^{271}$ Thomas Shillington (I835-1925), linen manufacturer and member of the Ulster Land Committee, lost the contest for Armagh North to Major E.J. Saunderson (Con.) by 4192 : 2373 .

${ }^{272}$ John Shaw Brown (b. I823), linen manufacturer, lost the contest for Down North to Colonel Thomas Waring (Con.) by 4315 : 284I.

${ }^{273}$ Sir William Huffington Findlater (I824-I9o6), Lib. MP for Co. Monaghan (I88o-I885), President of the Incorporated Law Society and the Statistical Society of Ireland, finished third in the contest for Londonderry South behind Timothy Healy (Nat.) and Colonel Hugh McCalmont (Con.).

${ }^{274}$ Timothy Power O'Connor (I848-I929), Nat. MP for Liverpool, Scotland Division (I88o-I929) and a vital link between Irish and Liberal parliamentarians; see his The Parnell Movement (London, 1886).
} 
party or Tory party numbering in Ulster i $6 \&$ with the two members for Dublin University making up a grand total of I8.

4 Jany. I886

The House of Commons now elected consists of Liberals - 335

Tories - 249

Nationalists - 86

Thus the Tories \& the Nationalists exactly balance the Liberals.

Since I last wrote in this diary, now nearly a month ago, several events of great importance have taken place. On the i 7 th December the Pall Mall Gazette \& the Standard published what purported to be the heads of a Home Rule scheme which Mr. Gladstone had matured. These heads were

I. A Parliament in Dublin.

2. A veto by the Crown on the advice of the Irish ministry.

3. Representation from Ireland in the Imperial Parliament.

4. The control of the police to be vested in the Irish Parliament.

5. Guarantees by Mr. Parnell for the protection of the Protestant minority in Ireland [and] for the recognition of the due rights of Irish landlords.

The publication of these heads of course excited a furious controversy in the press. The London press, except the Daily News \& Pall Mall Gazette, denounced the project, while many of the provincial papers, e.g. the Scotsman \& Liverpool Daily Post, supported it. Gladstone sent a carefully worded telegram denying that he had any hand in publishing the heads but not denying that they represented in the main his views. In fact, the contradiction left it open to him to adopt the heads or repudiate [them] at any future time according as he should see fit. ${ }^{275}$

Chamberlain \& Dilke at once began to sulk \& to say that it would probably be better not to oust the Tory party from office for the present. Chamberlain's speech was very sulky \& in the worst grace. He said let the Irish party now see what they can get from the Tories, their friends, \& when they find that they cannot get anything they

${ }^{275}$ Articles concerning Gladstone's position on home rule were published in the Daily Newes and the Pall Mall Gazette on 12 December and expanded upon in the Standard and the Pall Mall Gazette on 17 December: Herbert Gladstone to Lucy Cavendish, 3г December i885: GP, Add MS 56445, fos I $44^{-1} 54$. 
will be glad enough to take [from] the Liberals anything which the Liberals may choose to give them..$^{27}$

John Morley made a fine manly speech at Newcastle on Tyne insisting that Ireland should be allowed to get whatever measure of self government she required. ${ }^{277}$

Lord Hartington sent a carefully worded letter to one of his supporters in which he apparently protested against the heads but leaving [sic] himself a loophole for retreat. ${ }^{27^{8}}$

Mr. Forster denounced the scheme as revolutionary. ${ }^{279}$ A couple of days after the publication of the heads I saw Sir Robert Hamilton who said with glee, "did I not tell you that Gladstone was the man \& the one man in England who would have the courage and foresight to concede Home Rule to Ireland \& to carry it through Parliament". Sir Robert is now more eager and enthusiastic than I am myself for the speedy attainment of full legislative independence for Ireland. It is a marvellous change. By reference to my entries in this diary under the date of 27 June 1885 I see that at that time Sir Robert had not advanced beyond the notion of a Central Board elected partly by ratepayers \& partly by the managers of National Schools, \& which Board should not have any more extended powers than the management of the funds for primary education in Ireland, ${ }^{280}$ \& now within six months he has not alone considered as possible a complete scheme of Home Rule, but he is feverishly anxious for its immediate accomplishment.

We talked over the heads \& we both agreed that a scheme which would give Ireland a separate parliament and also representation at Westminster would be less feasible than one which would cut Ireland adrift from all interference in the Imperial Parliament.

On the morning of 26 th Dec. I885 I went to London, mainly with the view of seeing John Morley and talking over the situation with him. I went out to his house, Berkeley Lodge, West Hill, Putney on Sunday the 27 Dec. and the first person whom I met there was my

\footnotetext{
${ }^{276}$ Chamberlain spoke at Birmingham on 17 December and Dilke at Chelsea on the following day: The Times, I8 December I885, p. 7; 19 December 1885, p. 9.

${ }^{277}$ Morley addressed a meeting of the Liberal Five Hundred in the Northumberland Hall on 2I December: The Times, 22 December I885, p. 6; John Morley, Recollections, 2 vols (London, I923), I, p. 204.

${ }^{278}$ See The Times, 21 December 1885 , p. 9.

${ }^{279}$ William Edward Forster (I8I8-1886), Lib. MP for Bradford (I86I-I885) and for Bradford Central (1885-1886), Vice-President of the Council (1868-1874), Chief Secretary for Ireland (1880-1882). On 2r December, Forster wrote to The Times stating that home rule would not solve the Irish question and posed a danger to both Great Britain and Ireland: The Times, 23 December 1885 , p. 4.
}

\footnotetext{
${ }^{280}$ See Document 9.
} 
friend John Dillon MP. We had a long chat about Home Rule \&c. \& I found to my astonishment that Morley believed the Liberal party to be hopelessly broken up \& if the Tories were put out, that Gladstone would not be able to form a Cabinet. Mr. Frederick [sic] Harrison, ${ }^{281}$ the well known review writer, who joined us agreed in this opinion.

After John Dillon \& Mr. Harrison had left, I continued with Morley \& he told me then the reason why he believed the Liberal party to be disintegrated. He said that a couple of days after he had made his speech in Newcastle he had received a furious letter from Chamberlain, abusing him through all the moods and tenses for having in that speech given any encouragement to Gladstone in his Home Rule projects, \& saying that he, Chamberlain, \& Dilke were determined not to advance an inch beyond the National Council proposal in the Fortnightly Review article. The situation therefore is this. Gladstone \& Morley are sound on the Irish question, Hartington is more than doubtful, Lord Spencer's views are not known \& Dilke \& Chamberlain are in a sulky revolt. The outlook is certainly blue enough.

I said to Morley that if he thought I could do any good I would go to Birmingham to see Chamberlain \& try to talk him over. Morley jumped at this proposal \& said he would write to Chamberlain telling him of my visit to London \& asking would he wish to see me.

Two days afterward, Morley called at the National Liberal Club \& told me that Chamberlain had written asking me to go down to his place Highbury, Moor Green near Birmingham, to stay with him for a day or two \& talk matters over with him.

On the 3 ist December I went down to Chamberlain's house \& at once plunged into a discussion of the situation. I found Chamberlain personally polite, but shewing palpable signs of suppressed rage at the turn which things had taken. For an hour or so his every observation was directed to shew the impossibility of any scheme of Home Rule, $\&$ he even went so far as to say, "have you ever considered the contingency of the English people making up their minds that their legislative business must \& shall be attended to, \& then promptly suspending the constitution of Ireland for say ten years." I replied very calmly, "yes I have considered that contingency \& with great respect it strikes me that it is a contingency which an Irish Nationalist can view with less concern than can an English Radical".

\footnotetext{
${ }^{281}$ Frederic Harrison (I83 I-I923), President of the English Positivist Committee (I880I895), professor of jurisprudence, constitutional, and international law for the Council of Legal Education (1877-1889), defeated Liberal home rule candidate for London University (1886).
} 
"Why", said he.

"Because", I replied, "in the first place the process of carrying such a measure as the disenfranchisement of the Irish Nation is one which will occupy some considerable time, next when carried it will have placed in Ireland before the World with [sic] a grievance the comparison with which all grievances of which she has hitherto complained will be as nothing, \& lastly the ink with which the Queen will have signed her name to the disenfranchising Act will not be dry before whatever English party happens at the moment to be out of power will forthwith begin intriguing to repeal or amend the Act."

He paused for a few moments \& said then, with more quietness than he had shewn, "I believe you are right". "Now", said I, "let us calmly look at the question of Home Rule to see how even for England the advantages \& disadvantages balance each other" \& we then began our discussion with Chamberlain in the frame of mind which seeks to overcome, instead of raise, difficulties. By the way, I should mention that all this time his daughter was present and in the course of our discussion she occasionally interjected an observation. One of them amused me very much because it was such a delightfully clear proof of the belief which English people have at the bottom of their minds, that Irish members are not really citizens of the Empire with rights exactly equal to those of Englishmen. We were discussing the question of obstruction \& Chamberlain had said that if obstruction were tried it would be promptly suppressed by the suspension of the Irish members. I replied, "certainly it would be suppressed if it were perceived, but with so many members as 86 to work it it would not be perceived because it would take the shape not of persistent opposition to any one proposal, but rather that of a criticism on all affairs of the Empire". "But", said Miss Chamberlain, "if the Irish members began discussing \& criticising affairs of the Empire which did not concern them surely that would be obstruction". I smiled \& said quietly, "I think Miss Chamberlain that you are laying down a somewhat inconvenient doctrine. I thought the theory of your father's to be that Irishmen are citizens of the Empire with responsibilities \& rights equal to those of Englishmen \& if so surely they are entitled to interest themselves in all affairs of the Empire".

The upshot of the discussion was that Chamberlain admitted there were fewer objections to the following scheme than to any other

I. A Parliament in Ireland with two houses, an assembly \& a senate.

2. No representation of Ireland in the Imperial Parliament. 
3. Ireland to pay for the maintenance of say I0,00o or I2,000 Imperial troops in Ireland.

4. Ireland to take over her share of the National Debt.

He declined to pledge himself to support this, but before I left for Ireland I felt satisfied that I had succeeded in seriously modifying the views which he held before our discussion began, \& I now believe that there is not so much danger as there was of the Liberal party being disrupted by Chamberlain. Dilke will follow Chamberlain.

I returned to Dublin on the morning of the ist January \& on the 2nd I saw Sir Robert Hamilton \& told him what I had done. He was greatly pleased \& said that I had [done] a very useful \& important work in speaking to Chamberlain as I had done.

He said that Lord Spencer would be sound on the Irish question. After I had left I began to think that it would be very important to convey to Lord Spencer the fact of Sir Robert Hamilton having come round to the opinions which he now holds as regards Home Rule for Ireland, \& on yesterday I went out to the Under Secretary's Lodge to tell Sir Robert what I wished to do \& to ask him whether he would prohibit me from writing to Lord Spencer informing him of his (Hamilton's) opinion. Sir Robert then told me in strict confidence that he himself had written fully to Lord Spencer giving his opinion, \& that in doing so he considered he was not violating any official secret but that he was merely giving his own individual opinion..$^{282}$

I was very much pleased to hear that Sir Robert's opinions had been communicated to Lord Spencer, for I know how much Lord Spencer relies on Hamilton's judgement. If Spencer comes round he will be a potent factor in bringing round Hartington. All may still be well.

I dined last evening at the Jesuit College, Belvedere \& met T.D. Sullivan MP, ${ }^{283}$ William O'Brien MP, Dr. Kenny MP, Tim Healy MP, Mr. Clancy $\mathrm{MP}^{28} \&$ Sir Thomas Esmonde MP, the youthful member for Dublin County. He is only 22 or 23 years of age. I had a long chat with him \& I was greatly pleased with him. He is a very intelligent \&

\footnotetext{
${ }^{282}$ See Documents 32 and 37.

${ }^{283}$ Timothy Daniel Sullivan (1827-I9I4), Nat. MP for Co. Westmeath (1880-1885) and for College Green Division, Dublin (1885-1892), editor and proprietor of The Nation, Dublin Weekly Neres, and Young Ireland, Lord Mayor of Dublin (I886-1887).

${ }^{28}$ John Joseph Clancy (1847-1928), Nat. MP for Dublin North (1885-I9I8), member of the editorial staff of The Nation newspaper.
} 
thoughtful young man and unless I [am] much mistaken he will make a good figure in political life.

I7 Jany.

In the second last issue of the Statist there appeared a letter signed 'Economist'. It is believed to have been written by Mr. Giffen ${ }^{285}$ of the Board of Trade. It suggests as a preliminary to Home Rule for Ireland that all the landlords' interest in Irish land should be bought out on the following terms. The agricultural rental of Ireland is assumed to be about $£ 8$,ooo,ooo, which at 20 years['] purchase would represent I6o million sterling. This sum should be advanced to the Irish nation by means of consols, the annual interest on which would then belong to the Irish State who would be entitled to receive all the rent payable by the tenants. England would be paid this interest not by any cash payment from Ireland, but merely by the fact of England ceasing to contribute to local expenditure in Ireland what she now contributes \& which contributions the writer estimates at 4 millions a year. England would thus lose on the transaction only $f 800$, ooo a year, which the writer thinks the [illegible] will be satisfied to lose for such a purpose. ${ }^{286}$

The Irish State would then have the rental of Ireland for its revenue $\&$ the writer maintains that the Irish Exchequer could then afford to reduce very materially the rent payable by Irish tenants. The Statist \& the Pall Mall Gazette back up this proposal. ${ }^{287}$

I discussed it with Sir Robert Hamilton. He believes that Giffen is the author of the proposal. He thinks that Giffen underrates the agricultural rental of Ireland. Sir Robert says that the rental is about I2 millions a year of which about 3 millions represent demesnes \& farms in the owners' possession, leaving the rental payable by tenants to be about 9 million. It is somewhat strange to find how many people by different processes of reasoning are coming round to the notion that if public money is to be advanced for the purpose of buying out the landlord, it is the Irish Exchequer \& not the Irish tenant who should become the owner of the land.

\footnotetext{
${ }^{285}$ Robert Giffen (I837-I910), assistant editor of The Economist (I868-1876), Assistant Secretary of the Board of Trade and Controller-General of the Commercial, Labour and Statistical Departments (I882-I897), President of the Statistical Society (I882-I884), KCB (I886).

${ }^{286}$ See 'Home rule - a suggestion', The Economist, 9 January I886, reprinted in The 'Statist' on Ireland: reprint of 'Economist's' letters to the Statist on the Irish land and home rule questions, and of editorial comments thereon (London, I886).

${ }^{287}$ The scheme was lauded as 'a way in which the Irish difficulty can be settled with justice to all parties': $P M G$, I6 January I886, p. 6.
} 
I had a letter from John Dillon MP on yesterday. He is in London. He believes that Home Rule is still a long way off.

I have been reading the life of Francis Deak ${ }^{288}$ by the daughter of Mr. Forster's wife, a very interesting book at any time but especially at present. ${ }^{289}$ Deak was born in $1803 \&$ he was therefore 64 years of age when Hungarian independence was won in 1867 . The contest for her rights lasted in Hungary from i849. In i86i an attempt was made by the Emperor of Austria to come to terms with Hungary but the attempt failed. On this occasion Deak prepared an address to the Emperor in the course of which he made the following observation, which might with advantage be taken to heart by many of the writers who now flood the columns of the Times with letters denouncing any concession of legislative freedom to Ireland.

"A forced unity will never make the Empire strong; the outraged feeling of the individual states and the bitterness arising from the pressure of force awaken the desire for separation, and therefore the Empire would be weakest just at the moment when it would be in want of its united strength and the full enthusiasm of its peoples. The position of an empire as a great Power whose unity can only be maintained by force of arms is precarious and least safe in the moment of danger . . . ${ }^{290}$ Feelings and ideas will extend themselves; and because a 'centralised unity' is in opposition to the past of the individual lands to which they look back with pious recollection, and because it is opposed to the hopes they nourish for the future, the practical carrying out of 'centralised unity' will have to contend not only with hostile feelings; but in the course of open deliberations, with opposition and considerable difficulties. If therefore your majesty wishes your Empire to be free and really strong, your majesty cannot attain that object by a compulsory unity but by a mutual understanding arrived at through the free consent of the nation".

Commenting on this observation, the author says that it "is based not only on the opinion of a Hungarian patriot as to the form of administration best suited to his own country but on a broad principle of Government applicable to all states and in all times" ${ }^{291}$

\footnotetext{
${ }^{288}$ Ferenc Deák (1803-1876), Hungarian statesman and chief organizer of the Ausgleich or compromise with the Austrian crown in 1867.

${ }^{289}$ Florence Vere O’Brien (née Arnold-Forster) (1854-I936), adopted niece of William Forster and author of Francis Deak (London, I880): see T.W. Moody and R.A.J. Hawkins, with Margaret Moody (eds), Florence Arnold-Forster's Irish fournal (Oxford, I988), pp. xx-xxii.

${ }^{29}{ }^{\circ}$ Ellipsis in original.

${ }^{291}$ Fottrell reproduced a passage from pages $26 \mathrm{O}-26 \mathrm{I}$ of the book, which outlined the constitution of the Austro-Hungarian monarchy (1867).
} 
27 Jany.

I went to London on the night of the $22^{\text {nd }}$ inst. While there I had interviews with Charles Russell QC, John Morley MP, Mr. Giffen of the Board of Trade \& John Dillon MP.

Russell has been on a tour in the south of Europe during which he spent a few days with Sir Charles Gavan Duffy. The effect of this conference is very manifest. Russell has learned something about Home Rule. He has been as a rule too busy to learn much about it. His notions have been crude, and while he has been very radical on the subject of Irish law I have always found that he had very erroneous views on the subject of Home Rule. For example, he has kept on for years telling me that Home Rule was steadily declining as a cause. Duffy has, I think, convinced him of some of his errors \& on the whole I am disposed to think that Russell has now some grasp of the subject, but he is out of touch with Irish sentiment. For example, he was quite astonished when I told him that the Irish party would be quite satisfied to have Home Rule without any representation in the Imperial Parliament.

John Dillon is in good spirits. The Queen's Speech was delivered on Wednesday the $20^{\text {th }}$ inst. For several days previously there were all kinds of wild 'blood \& thunder' statements in the London press in reference to the intentions of the Government regarding Ireland. Martial law, suppression of the National League \& all kinds of stringent coercion were put forward as being the policy of the Government. In Ireland, we nationalists of the moderate type were in low spirits. We found that the old weary round of coercion \& retaliation was about to be travelled. The Queen's Speech came. It was a curious pronouncement. It said that serious crime had not materially increased in Ireland, but that intimidation had been resorted to prevent people from carrying out their contracts and that organised opposition to the payment of full rents had been manifested in parts of the Country, \& it added some words to the following effect

"If, as the information at my disposal would lead me to believe, the forces of the existing law shall prove inadequate to cope with the increasing evils I rely upon my Parliament to arm the executive with ample powers to deal with them". ${ }^{292}$

Sir Michael Hicks-Beach made a speech on the address in which he shewed that the state of the Country as regards crime was not serious, but he dwelt upon the boycotting \& similar evils which he deplored

\footnotetext{
${ }^{292}$ The speech read, 'If, as my information leads me to apprehend, the existing provisions of the law should prove to be inadequate to cope with these growing evils, I look with confidence to your willingness to invest my Government with all necessary powers': Hansard, CCCII, cols $3{ }^{2-} 3^{6}$.
} 
but still he did not urge that coercive measures should be at once adopted. ${ }^{293}$

Gladstone made a very adroit speech in which he did not commit himself to any definite scheme of Home Rule but plainly enough left the impression that Home Rule \& nothing else could render Ireland what she ought to be. ${ }^{294}$

Parnell also spoke very adroitly \& with great moderation shewing that Home Rule did not mean separation but quite the opposite, shewing that ample guarantees would be given if demanded for the protection of the minority in Ireland \& that as regards the land question some such scheme as Giffen's would be supported by the Irish party. ${ }^{295}$

Neither Gladstone nor any of the Irish members moved an amendment to the address. The Tories were quite deceived in the tactics of both Gladstone \& Parnell. They were certain that either of them would move a Home Rule amendment and that they, the Tories, would have had an opportunity of going out on the cry of 'the integrity of the Empire'.

On Friday the $22^{\text {nd }}$ inst., it was announced to the astonishment of everyone that Mr. W.H. Smith has been appointed Chief Secretary for Ireland. ${ }^{296}$ Lord Carnarvon had previously stated publicly his intention of resigning the Vice Royalty.

The object of Mr. Smith's appointment it was not easy to see. On Monday the $25^{\text {th }}$ inst., Lord Salisbury announced portentously that Mr. Smith, who had crossed over to Ireland on Saturday, would at once make a report to the Cabinet about the state of the Country, \& that the Government would be prepared within 24 or 48 hours to state their intentions as to repressive legislation. On Tuesday the $26^{\text {th }}$ inst., Sir Michael Hicks Beach announced in the House of Commons that the ministry would ask to have the discussion of the address to the Queen's Speech adjourned in order that they might introduce a bill proclaiming the National League to be an illegal association \& enacting the boycotting provision of the Crimes Act. ${ }^{297}$ Mr. Jesse Collings's amendment as to the importance of compulsory powers given to local bodies to enable them to obtain allotments for labourers was moved, \& on it the ministry was defeated by a majority of 79 .

\footnotetext{
${ }^{293}$ Ibid., cols I20-I30.

${ }^{294}$ Ibid., cols IOO-I2O.

${ }^{295}$ Ibid., cols $\mathrm{I} 5 \mathrm{I}-\mathrm{I} 6 \mathrm{o}$.

${ }^{296}$ Ibid., col. 68; The Times, 22 January I886, p. 6.

${ }^{297}$ See Hansard, CCCII, cols 300-30I, 4I6.
} 
With the ministry voted Lord Hartington, Sir Henry James, ${ }^{298}$ Leonard Courtney ${ }^{299} \&$ Goschen. ${ }^{300}$

Now to go back to my interview with John Dillon. I saw him on Sunday the $24^{\text {th }}$ inst. He therefore did not know of the intended coercion move of the Tories. He considered that Gladstone had outwitted the Tories \& that his attitude was a clear confession of his intention to work up to Home Rule. Dillon praised Giffen's scheme, said Parnell was quite taken with it and expressed his opinion that probably a scheme on the lines of Giffen would be carried this session \& that it would lead next session to Home Rule.

On Saturday the $23^{\text {rd }}$ inst. I had an interview of about an hour's duration with Mr. Giffen. I found him a most interesting man. A canny Scotchman with plenty of shrewd sense but also with remarkable boldness of mind. He explained his scheme fully to me. He told me it was produced owing to several conversations at the Athenaeum Club with many politicians. I told him that Sir Robert Hamilton considered that he, Giffen, underestimated the agricultural rental of Ireland. Giffen said that this was not his opinion. I said that Hamilton estimated the gross agricultural product of Ireland at 6o millions \& that the rental was probably one fifth of this. Giffen said that Sir Robert was quite out in his calculation; that the gross products were only 40 millions \& that if the rental was really I2 millions it was one which could not be paid by the agriculturalists. Giffen said that in the Economist of this week there is a letter from a Mr. Harris who is a good authority on the subject \& in his letter he contended that the gross product of Ireland was only 36 millions. ${ }^{301}$

I told Giffen what were Sir Robert's views about the necessity of granting Home Rule \& of beginning not by County Boards but by conceding the central Parliament. Giffen was greatly interested at hearing that Sir Robert had come around to this view \& plainly he is himself quite prepared to acquiesce in the wisdom of Sir Robert's view.

\footnotetext{
${ }^{298}$ Sir Henry James (I828-I9II), first Baron James of Hereford (I895), Lib. MP for Taunton (I869-I885), Lib. U. MP for Bury (I885-I895), Attorney-General (I873-I874, I88o-I885).

${ }^{299}$ Leonard Henry Courtney (1832-I9I8), first Baron Courtney of Penwith (I9o6), Lib. MP for Liskeard (1876-1885), Lib. U. MP for Bodmin (1885-1900), Financial Secretary to the Treasury (1882-I885).

${ }^{300}$ George Joachim Goschen (I83I-I907), first Viscount Goschen (I900), Lib. MP for Ripon (I880-1885) and for Edinburgh East (I885-1886), Lib. U. MP for St George's (I887-1890), Chancellor of the Exchequer (1887-1892).

${ }^{301}$ William James Harris (1835-191 I), Con. MP for Poole (I884-1885); see The Economist, 23 January I886, pp. II2-II3.
} 
On Sunday the $24^{\text {th }}$ inst. I lunched with John Morley at his home at Putney. We had a long chat about the political situation. He told me that Chamberlain kept straight for about a week after my interview with him but that he had then relapsed into his sulks \& kept swearing that the Home Rule scheme would ruin the Liberal Party. It appears that he even went so far as to contemplate \& feel his way for the establishment of a Hartington-Chamberlain alliance against Home Rule but that his radical friends plainly told him that such an alliance would mean his absolute ruin and effacement as a politician.

Morley praised Giffen's scheme \& he said he had heard that Chamberlain was writing an article in the Fortnightly Review in support of it. Morley mentioned that in the course of the debate on the address to the Queen's Speech he believed Goschen would speak on Ireland \& that if so he Morley would answer him. I suggested certain topics for Morley's speech \& when we were walking down to the station Morley said with a laugh "I wish Fottrell you would come over here about once every ten days and coach me for a speech". He had no inkling of the ministry being so near their death as the event proved them to be. I spoke to him about the Irish Chief Secretaryship \& I said that if Gladstone did come into office \& if he Morley believed that Gladstone was really about to face the Irish problem in a bold way, it would be of great service to have him (Morley) accept the post of Chief Secretary.

$3^{\text {rd }}$ February

On Thurday the $28^{\text {th }}$ Jany. Sir Michael Hicks Beach announced that Lord Salisbury had gone to the Queen but that he was not in a position to state what statement he would make to her Majesty. The House adjourned then to Monday I ${ }^{\text {st }}$ Feb. On Monday I ${ }^{\text {st }}$ Feb. Sir M. H. Beach announced that Lord Salisbury had resigned \& that the Queen had sent for Mr. Gladstone. ${ }^{302}$

On Sunday the $3 \mathrm{I}^{\text {st }}$ Jan. I had a long chat with Sir Robt. Hamilton. We discussed the situation. He is quite hopeful of Gladstone's will \& power to carry Home Rule. We discussed the Chief Secretaryship \& spoke about the rumour that either Chamberlain or Childers would be the man selected. Morley had written to me to this effect. Sir Robert agreed with me that neither one nor other of these men would suit. Chamberlain he does not personally know but from my account of him he distrusts him \& as regards Childers he has the poorest opinion of his ability, manliness or generosity \& he went so far as to tell me that he had written to Lord Spencer, not quite to the effect that he, Hamilton, would not serve under Childers, but intimating that his service under

${ }^{302}$ Hansard, CCCII, cols 532-533, 534-535. 
Childers would be so unsatisfactory that he should probably ask to be removed from the Under Secretaryship. ${ }^{303}$ Hamilton said as regards Giffen's scheme that a further examination of the figures led him, Hamilton, to put the gross agricultural return of Ireland at about 50 millions per annum instead of 60 millions. Later in the day I saw Davitt \& John Dillon \& I discussed with them the question of the Chief Secretaryship. They both scouted the idea of either Chamberlain or Childers being sent over. I asked their opinion as to the wisdom of selecting John Morley for the post \& they both replied almost in the same terms that they would be sorry to see Morley come here because they had too great a respect and love for him to wish that he should run any risk of losing his popularity in Ireland, or be subjected to the pain of feeling that he was ostracised from the friendship of the Nationalist members who are now friends of his. Both Dillon \& Davitt seemed to think that Mr. Fowler ${ }^{304}$ would be a good selection for the Secretaryship. By the same post I wrote to Morley telling him what Davitt \& Dillon said \& on this morning I recd. from him a pathetic letter telling me he had accepted the Secretaryship \& that my letter had made him very sad. It is the letter of an honest man. He marked it private but added that I might show it to John Dillon, of whom he speaks in terms of great esteem and affection.

I forgot to note in its place a fact of some significance. On the $27^{\text {th }}$ ultimo, the day after the defeat of the Conservative Government, I was at the Castle \& in the course of conversation with Sir Robert Hamilton he mentioned to me that there had been some serious cases resulting from boycotting and as an instance he read for me the report of Major Butler, ${ }^{305} \mathrm{RM}$ for the Mallow District of Cork, a case of which the following were the facts.

A, a farmer, had six years ago taken a farm from which B had been evicted. B recently claimed the farm as his. A naturally demurred \& pleaded that he had been six years in undisturbed possession, but yielding to local National League pressure or advice he offered to give to $\mathrm{B} \delta 25$ as compensation for his supposed claim, B agreed \& was paid $\hat{E} 5$ on a/c but afterwards he repudiated this bargain \& claimed the farm itself. A of course defied him \& held possession. Some few days ago A proceeded to a forge to get his horse shod \& when coming home from the blacksmiths he was violently assaulted by B. A promptly summonsed B before the magistrates who thereupon summoned as

\footnotetext{
${ }^{303}$ See Document 40.

${ }^{304}$ Henry Hartley Fowler (I830-I9II), first Viscount Wolverhampton (I908), Lib. MP for Wolverhampton East (I880-I908), Under-Secretary of the Home Office (I884-I885).

${ }^{305}$ Thomas Butler (I837-I920), RM for Mallow, advocate of Irish administrative reform.
} 
a witness the blacksmith, who gave his evidence very reluctantly. B was sentenced to a short imprisonment \& was bound over to keep the peace. The next step was the summoning of the blacksmith before the Freemount Branch of the National League to give an explanation of why he had given evidence in favour of $\mathrm{A}$, a boycotted person. On this state of facts Major Butler reported \& urged that notice should be taken by the Executive of this attempt to override the lawfully constituted courts of the Country. I expressed my opinion that the case was outrageous \& Sir Robt. told me he was sending it down to Captain Plunkett, ${ }^{306}$ the RM of Cork, for prompt investigation.$^{307}$ I said that probably I could get the case dealt with in a more summary \& effective way than Capt. Plunkett could \& I straight away went off to T. Harrington MP, the Secretary of the Central National League, \& I told him all the circumstances. Harrington at once promised to look into the case \& that if the facts were as I stated he would at once dissolve the Freemount branch of the League. Two days afterwards an announcement appeared in the Freeman stating that the branch had been dissolved..$^{308}$

I then told Sir Robt. Hamilton what had been done \& I suggested that Capt. Plunkett should be told to let the matter drop \& Sir Robt. promised he would send word to him to this effect. ${ }^{309}$ Sir Robert was greatly pleased at the result of my intervention \& said that if I could succeed in getting a few similar things done I would probably be the means of accelerating Home Rule by a year or two.

I6 Feby.

The principal members of the new Liberal Administration whose seats have been contested on their seeking for re-election are Charles Russell \& John Morley. Russell as Attorney General for England, Morley as Chief Secretary for Ireland. Both men were pronounced in their Home Rule declarations. Russell has been returned by an increased majority of 253 over that which he obtained at the General election, his majority now being II95 against 942 then. Morley has won by a majority of 266I against his former majority of 629. The exact numbers at the General election were as follows,

\footnotetext{
${ }^{306}$ Thomas Oliver Westenra Plunkett (1838-I889), son of the twelfth Baron Louth, RM (I866-I88I), SRM and DM for South-Western Division (I88I-I889).

${ }^{307}$ Butler to Hamilton, 26 January I886; Hamilton to Plunkett, 27 January i886: CSO RP 1886/1707 in RP г886/2602; Cork Examiner, 26 January i886.

${ }^{308}$ See $F \mathcal{F}$, 29 January i886, p. 5 .

${ }^{309}$ It was reported that this action was met 'by the farming class with great satisfaction': Hamilton to Plunkett, 29 January I886; Plunkett to Hamilton, 9 February I886: CSO RP I886/2602.
} 


\begin{tabular}{|c|c|c|}
\hline Cowen ${ }^{310}$ & 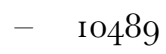 & His recent election shewed the \\
\hline Morley & 10129 & following result, \\
\hline Hammond $[s i c]^{311}$ & 9500 & $\begin{array}{l}\text { Morley } \\
\text { Hammond [sic] }\end{array}$ \\
\hline
\end{tabular}

The result of the Newcastle election shews that Morley got all the Liberal votes which he had at the General election \& in addition got all the Irish vote \& probably some few extra Liberal votes. ${ }^{32}$ The Irish strength is variously estimated at from $\mathrm{I} 500$ to 2000.

Two days before the election Morley came over to Dublin to be sworn in as Chief Secretary. ${ }^{313}$ I saw him at the Castle for a few minutes. He was anxious \& nervous. I tried to cheer him up \& told him that the National party would give him every fair play. He said he felt sure they would treat him generously but he was appalled at the magnitude of the task which had been laid upon him, a task which he said would have been heavy for a Napoleon or Frederick the Great, and in carrying out which he felt so hampered by the fact that almost all Englishmen were so ignorant of the affairs of Ireland that it was difficult to convince them of the wisdom of any step which he as Chief Secretary might take.

He asked me did I think that Parnell would be satisfied to let the Government deal first with the Land Question \& leave Home Rule in abeyance till the Land Question should have been settled.

I replied that I thought not but that I would make careful enquiries. Subsequently I did make careful enquiries from John Dillon, Dwyer Gray, Harrington \& Leamy ${ }^{34}$ \& I felt satisfied from these enquiries that Parnell had made up his mind to oppose most determinedly any proposal for giving the Land Question precedence of Home Rule. His view is I think a sound one. He considers that the Land Question has reached such a pass that it must be settled \& that no matter what ministry may be in power they must deal with that question, but he also considers that no statesman except Gladstone could carry Home Rule, that Gladstone is 76 years of age \& therefore a precarious life \& that ergo it behoves the Irish party to insist upon Gladstone at once forcing the Home Rule problem.

\footnotetext{
${ }^{{ }^{10} \mathrm{~J}} \mathrm{Joseph}$ Cowen (183 ${ }^{\mathrm{I}-\mathrm{I} 900)}$, coal-owner and newspaper proprietor, Lib. MP for Newcastle upon Tyne (1874-1886), radical reformer and home ruler.

${ }^{311}$ Charles Frederic Hamond (I8I7-I905), Con. MP for Newcastle upon Tyne (I874-1880, I892-I900).

${ }^{3{ }^{12}}$ See The Times, I2 February i886, p. 6; I3 February i886, p. 6.

${ }^{313}$ He was sworn in on Io February I886: The Times, i February i886, p. Io.

${ }^{314}$ Edmund Leamy (I848-I904), Nat. MP for Waterford city (I880-I885) and for Cork North East (1885-1887).
} 
Accordingly I wrote very fully to Morley urging that the Cabinet ought to deal with the Land Question \& with Home Rule in the one bill, \& saying that in my opinion a bill dealing with both questions would for the purpose of commanding Tory support be better balanced than if it dealt with only Home Rule, \& would for the purpose of commanding Irish national support be better balanced than if it deal $[s i c]$ exclusively with the Land Question.

A few days ago I had a characteristic letter from Charles Russell in which he said that if Home Rule were to be pushed forward now its fate would be sealed for years, because there is a strong feeling in England against any such measure \& that nothing but time \& discussion could remove this feeling \&c. \&c. I replied pointing out that his election \& Morley's seemed rather to demolish his theory about the strong antiIrish feeling in England \& I added that while there might be some risk in Gladstone straightaway formulating his Home Rule plans, I was satisfied the risk was one which he would have to face, because if he did not face it he would have to face the bigger risk of losing the Irish vote. On today I got a letter from Charley Russell, his son, written by direction of Charles Russell himself in which he repeats his observation about the anti-Irish feeling in England, says that it may become less "six months hence" \& says that with the exception [of] Gladstone \& Morley all the members of the Cabinet are opposed to the Parnellites. This shews an ignorance of the state of affairs in London which is to my mind simply astounding.

I have it on what I consider to be the very best authority that Lord Spencer is as keen for Home Rule as Parnell himself, that Mundella ${ }^{315}$ professed himself converted to the urgent necessity for Home Rule that Childers is of the same opinion \& so is Campbell Bannerman, and that the only really determined opponent of Gladstone in the Cabinet is Chamberlain.

I saw Sir Robert Hamilton today. He has been in London for the past 3 or 4 days. He has discussed the situation with every member of the Cabinet save Trevelyan, Childers \& Lord Rosebury ${ }^{316}$ and after the discussion he is satisfied that the state of affairs is hopeful. I told him Russell's view \& he simply laughed at his want of knowledge of the views of the Cabinet. He is enthusiastic in his admiration of the thorough way in which Lord Spencer has thrown himself into the

\footnotetext{
${ }^{315}$ Anthony John Mundella (I825-1897), Lib. MP for Sheffield (I868-I885) and for Sheffield Brightside (1885-1897), advanced Liberal and supporter of home rule.

${ }^{{ }^{16}}$ Archibald Philip Primrose (I847-1929), fifth Earl of Rosebery (I868), Lord Privy Seal (1885), Foreign Secretary (1886, I892-I894), Prime Minister (I894-1895).
} 
fight in favour of Home Rule. He said that Lord Spencer's views are as advanced as his own.

I told him what I had written to Morley about Parnell's resolve \& he said "Parnell is quite right. If I were in his place I would oppose any dealing with the Land Question in priority to Home Rule. They ought to be both taken up together".

He said he had in London spoken to both Giffen \& Fowler of the Board of Trade \& that Giffen had admitted he had not fully thought out the details of his scheme. Hamilton considers that John Dillon's plan of naming a fixed number of years['] purchase at which every Irish landlord would be entitled to demand from the Irish state the purchase of his estate is more likely to be carried out than a plan like Giffen's for the compulsory expropriation of all landlords. Hamilton thinks that

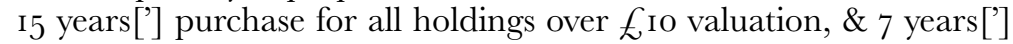
purchase for all holdings under $\mathcal{E}_{\mathrm{I}} \mathrm{o}$ valuation, would be a reasonable price to fix as that at which the Irish state could be compelled to buy. I said that the Irish people ought to give the landlords more than the commercial value of the land so as to settle the question. Yes said Sir Robert, but remember that the English people are to guarantee the price \& England is so depressed at present that she will not tamely submit to guaranteeing any exorbitant price. He read for me a letter to him from Sir Thomas Farrer ${ }^{317}$ giving the strictly economic view of the value of small holdings in Ireland. Farrer says that the rent should be arrived at by deducting from the gross produce of the land the amount necessary for the subsistence of the tenants or the amount necessary for the eviction \& emigration of the tenants. Either deduction would I fear shew that a large proportion of the land in the west of Ireland can produce no rent \& that therefore strictly speaking it has absolutely no purchase value.

The Irish party has during the past ten days gone through a crisis which went near to breaking up the party. Parnell without consultation with or notice to his colleagues sent Captain O'Shea ${ }^{31^{18}}$ down to Galway City with a recommendation to the Electors to return him for their borough. O'Shea was a Whig and is - well no one knows what he is except that he is the husband of Mrs. O'Shea. ${ }^{319}$ The news reached Dublin on the night of last Thursday week. It was kept a secret till

\footnotetext{
${ }^{3{ }^{17}}$ Sir Thomas Farrer (1819-1899), first Baron Farrer of Abinger (I893), Permanent Secretary to the Board of Trade (I865-1886).

${ }^{3{ }^{18}}$ William O'Shea (1840-1905), Nat. MP for Co. Clare (1880-1885) and for Galway town (I886), facilitated communication between leading Liberal politicians and Parnell during I880-I885.

${ }^{319}$ Katherine O'Shea (I845-I92I) married William O'Shea in I867 and, as Parnell's mistress, acted as go-between in his dealings with Gladstone. Divorced in I89o, she married Parnell in I89I.
} 
Saturday morning when an announcement of the fact appeared in the Freeman. On this Friday night, as Edmund Dwyer Gray told me, there was a meeting of some of the Irish members including Timothy Healy which lasted till $4 \mathrm{am}$. To the consternation of the Irish party Healy \& Biggar ${ }^{320}$ without any mandate from the party, rushed down to Galway on Saturday morning \& forthwith publicly denounced O'Shea \& supported Lynch, ${ }^{321}$ a local nationalist. There was at once a private meeting held of all or most of the nationalist members in Dublin \& they resolved that Parnell's authority should be upheld even although they hated O'Shea \& finally a declaration to the effect was signed by over 50 of the members \& published in the Freeman..$^{322}$ The morning on which this declaration appeared Parnell turned up in Dublin from London \& went down to Galway where he met Healy \& Biggar, \& forthwith their candidate was withdrawn \& two days later O'Shea was returned. Parnell produced a document purporting to have been signed by O'Shea a fortnight before the election in which he bound himself by the pledge taken by all the Nationalist candidates at the General election.

The anxiety throughout Ireland during the period which elapsed between Healy's arrival in Galway \& Parnell's appearance there was simply electric, for there was a dread that the party was about to be hopelessly split up.

Three or four evenings afterward I met at the National League rooms Healy, Harrington, Leamy, Deasy ${ }^{323}$ \& T.P. O'Connor. The storm had then blown over.

The Divorce Case of Crawford \& Crawford \& Dilke was tried on last Friday. ${ }^{324}$ It resulted in the dismissal of the bill as against Dilke but it also, in my opinion, resulted in his irretrievable ruin. Crawford, the husband, was examined \& he detailed the confession made to him by his wife which justified all even the wildest rumours which were current in London when the Dilke scandal was first mentioned. Mrs. Crawford did not appear \& the hearsay evidence of the husband detailing the wife's confession was not technically evidence against Dilke, although it was evidence against Mrs. Crawford herself \& therefore the judge pronounced a decree of divorce against Mrs. Crawford but dismissed the bill as against Dilke. Dilke was represented by Charles Russell \&

\footnotetext{
${ }^{320}$ Joseph Gillis Biggar (I828-I89o), Nat. MP for Co. Cavan (I874-I885), pioneer of 'obstruction' in the House of Commons.

${ }^{321}$ Arthur Alfred Lynch (I86I-I934), colonel of the 2nd Irish Brigade, South Africa (I899I902), Nat. MP for Galway city (I9OI-I903) and for Clare West (I909-I9I8).

${ }^{322}$ See Ff, ro February i886, p. 6; Lyons, Parnell, pp. 314-340.

${ }^{323}$ John Deasy (I856-I896), Nat. MP for Cork city (I884-I885) and for Mayo West (I8851893), prominent member of the Irish National League.

${ }^{324}$ See The Times, I3 February I886, p. I2.
} 
Sir Henry James \& Russell, who as Attorney General 'led' in the case, made the astounding statement that after anxious consultation as there was no legal evidence against Dilke he had resolved not to put Dilke in the witness box to be cross examined about all the indiscretions of his previous life - needless to say that everyone must after this believe Dilke either guilty of the horrible transaction which Mrs. Crawford confessed to her husband, or guilty of the unspeakable meanness of abstaining from getting into the witness box to clear the character of a woman who, in a moment of phrenzy, had invented against herself and him a tale which blasted her reputation. On the whole it would have been as well if Chamberlain had not (as he told me he had) prevented Sir Charles Dilke from emigrating to the Antipodes when the scandal was first broached.

\section{March ist}

About a week ago I got a letter from Charles Russell saying that he still adhered to his own view as to the desirability of dealing first with the Land Question \& leaving Home Rule in abeyance, but he added "as you \& Mr. Parnell have arranged that a different course is to be followed this puts an end to discussion". I thought that this sneer was quite uncalled for \& I wrote a pretty tart reply to the Attorney General which brought from him a letter of explanation denying any intention of sneering \& saying that he valued very highly my opinion, \& in this letter he asked me to write for him a memorandum putting forth my views as strongly as I could \& that he would bring my views before Mr. Gladstone.

I prepared this memorandum ${ }^{325} \&$ sent it to Russell a few days ago \& I have received from him a letter in which he says "I think the order will be (a) a big land scheme but (b) dependent upon and of non effect without Home Rule, for the working it out will be the [?] new Irish Authority. If you ponder over this you will I think see it is very cleverly devised. Whether the whole thing will come out at once, i.e. in April, I don't know, but you may rely upon it the several parts will be independent".

I wrote saying that this line of policy met my difficulty in as much at it withheld from the landlords in Ireland a settlement of the Land Question until they swallow Home Rule. My whole contention was that the desire of the landlords for the settlement of one question should be used as a lever for securing the settlement of the other.

\footnotetext{
${ }^{325}$ See Journal (12, 21 March 1886).
} 
When I was in London last I, in speaking to Mr. Giffen, incidentally mentioned that Alderman Dillon, ${ }^{326}$ the father of John Dillon MP, had some years ago written for the Dublin Corporation a report upon the taxation of Ireland in which he shewed that Ireland was too heavily taxed in proportion to her resources. ${ }^{327}$ Giffen replied that he had never heard this alleged but he said he would look carefully into the question of Ireland's contribution. In the Nineteenth Century of this month there is a very important article by Giffen in which he states that Ireland contributes annually three millions more in taxes than she ought to pay \& that England loses three millions more in useless expenses in Ireland, i.e. the expenses of an over grown military \& police establishment \&c. ${ }^{328}$ The article is a very remarkable one \& will I have no doubt have a great effect on the English view. A new election has taken place in Cardiff where Sir E.J. Reed, ${ }^{329}$ who got some small office under Gladstone had to seek re-election. The Irish vote was cast for him. The result is encouraging. At the General election he won by about Ioo, he has now won by about $95^{\circ}$ which would tend to show that Wales is not frightened by the bug bear of Home Rule for Ireland. ${ }^{33^{\circ}}$ We are marching steadily on.

\section{March I2}

On Saturday last, the 6th inst., I received a telegram from Charles Russell, the Attorney General, asking me to go over that night to London as it was important he should have a conversation with me. I went over \& found that what he wanted to speak to me about was the Land Purchase Bill, which is in course of preparation by the Cabinet. He told me that he had been consulted by Gladstone \& that he had been present at some official Cabinet meetings at which Mr. Stanislaus Lynch, ${ }^{3{ }^{31}}$ the Land Purchase Commissioner, was also present, but that

\footnotetext{
${ }^{326} \mathrm{John}$ Blake Dillon (1814-1866), staff member of The Nation and Young Ireland, alderman of the city of Dublin, founder of the National Association, Lib. MP for Co. Tipperary (1865-1866).

${ }^{327}$ Report on the State of the Public Accounts between Ireland and Great Britain (1863, published Dublin, I882).

${ }^{328}$ Robert Giffen, 'The economic value of Ireland to Great Britain', Nineteenth Century, I9 (March I886), pp. 329-345.

${ }^{329}$ Sir Edward James Reed (1830-1906), Chairman of Milford Haven Shipbuilding \& Engineering Company, Lib. MP for Cardiff (1880-I895, I900-I906), Junior Lord of the Treasury (1886).

${ }^{33^{\circ}}$ Reed beat the Conservative candidate by $5708: 4845$ (see The Times, I March I886, p. 7).

${ }^{331}$ John Stanislaus Lynch (I83I-I9I5), Registrar of the Landed Estates Court and land purchase commissioner; see his 'Suggestions for the simplification of the procedure in relation to the sale of land in Ireland', presented to the Statistical and Social Inquiry Society of Ireland, 28 April I885, and The Times, in May I885, p. 7.
} 
at none of the consultations had Gladstone opened his entire scheme \& that he (Charles Russell) found it difficult to advise on any point without having before him the entire scheme for land purchase \& Home Rule. He asked me to draft for him a memorandum, which he could forward to Mr. Gladstone, embodying his views on the land purchase scheme \& on its dependence upon Home Rule. He gave me a sheet of note paper on which he had jotted down a few heads.

I went to work \& drafted a portion of the memorandum.

On Sunday 7 th inst. this conversation took place. On that day we had at lunch at 86 Harley St (Russell's house) Stanislaus Lynch, Samuel Walker (Attorney General for Ireland), The MacDermot (Solicitor General for Ireland), Thomas A. Dickson \& myself. After lunch the Land Question was discussed. I was amused to find that both Lynch \& MacDermot started by assuming that the basis of purchase was not what the tenant could be expected to pay as rent or annual instalments but what the landlord might expect to receive as purchase. Their argument was: Buy out the landlord by giving him a certain number of years' purchase of the existing rent and then reduce the tenant's rent by charging him interest at the rate of $f_{3}$. IO.O per cent on the amount of purchase money \& charge him no sum as a sinking fund. I ventured to ask who was to collect the interest \& they said the Irish Exchequer, "but", said I, "what interest will the Irish Exchequer have in collecting the interest if you start by giving out \& out to the landlord the highest sum you can screw up his compensation to by reducing, as you propose to do, the tenant's instalments to $£ 3$.IO.o per cent on the purchase money, a reduction which will have no possible margin of profit for the Irish Exchequer".

In addition to the persons whom I mentioned as being present at lunch there was a Mr. Henniger Heaton, ${ }^{332}$ MP for Canterbury, a Conservative. I think he must have gone straight to some Conservative club \& told all that he heard at Stanley St. because next day there appeared in the St. James Gazette a paragraph stating that several gentlemen who had lunched at Russell's were in London to be consulted by the Cabinet on the Irish Question. I was described as "Mr. George Fottrell late solicitor to Mr. Parnell and the Irish Land Commission." "333 After lunch Russell \& I took a walk \& called on John Morley, \& Chamberlain, neither of whom happened to be at home.

\footnotetext{
${ }^{332}$ John Henniker Heaton (I848-I9I4), landowner and newspaper proprietor, Con. MP for Canterbury (1885-1910).

${ }^{333}$ St. Fames's Gazette, 8 March I886, p. 8.
} 
Next morning, Monday gth March, I had a post card from Morley appointing an hour to see me at the Irish Office. I called and found him in good spirits. He is hopeful. I explained my views as to land purchase \& I found he agreed with me in the main. He then asked my opinion as to whether or not Ireland should in the event of Home Rule being granted send members still to Westminster. I replied that as far as the Irish people were concerned they cared very little whether members would still be sent to Westminster or not, but that I fancied it would be easier in England to carry a scheme which would contemplate Ireland continuing to send representatives (very much reduced in number) to Westminster than to carry a scheme which would cut Ireland adrift from the Imperial Parliament. I also urged Morley to insist upon there being two chambers in Ireland.

I asked him about Chamberlain. He believes that Chamberlain is casting about to see could he carry a party with him if he abandoned the Cabinet. I asked did he, Morley, think I could do any good by speaking with Chamberlain \& he said he thought it might be useful for me to do so, but he had not much hope I should be able to influence him.

Late in the day I was at the House of Commons \& I had a long chat with John Dillon MP \& with Wm. O'Brien MP. I found that O'Brien had very shadowy notions on the subject of land purchase. He seemed in some vague way to suppose that the circumstances of every estate would have to be investigated by a Commission who would fix the price at which the landlord was to be compulsorily bought out. I said that if this plan was to be followed it would take 50 years to make any impression. I said that there must be a uniform rate of purchase laid down in the Act of Parliament \& that there should be no compulsory powers sought for purchasing out the landlords; because compulsion would not be necessary \& because it would involve too high a price being fixed as the rate for purchase. But, said O'Brien, if there be no compulsory provision obliging Irish landlords to sell, how are we to make them sell. "Simply enough" I replied. "Landlords in Ireland will have the choice of selling or of abiding by such legislation as an Irish Parliament will pass \& I think that the alternative open to them will induce a large number to sell quickly enough." O'Brien said that the Imperial Parliament would never deal in this fashion with the Irish landlords. John Dillon took a different view \& said that he believed my view was sound.

While standing in the lobby of the House of Commons I met Lord Spencer who chatted with me for a few minutes \& asked me to call on him at Spencer House on the following morning so that he might have a conversation with me. 
I had a long talk with Thomas Sexton MP. He too is very hopeful. I did not discuss details with him.

I went to hunt up Mr. Chamberlain. I found him in a room at the foot of the staircase which leads to the Strangers Gallery. The ministers have each a private room within the precincts of the House of Commons.

Chamberlain was at work with some papers \& was smoking a cigar. We plunged at once into a discussion of the 'situation'. "We are in an eddy at present" said he with a smile. "Yes", said I, "there is a strange sensation among public men at present. A kind of suppressed excitement \& a vague expectation. What is it to come to". "Well", said he, "I have not changed the opinion which as I told you I had formed when last I saw you. We English people may possibly grant Home Rule to get rid of the Irish members, but I think they are not such fools as to grant Home Rule and at the same time pledge their credit for an enormous sum to buy out Irish landlords." "Well", said I, "in the first place I don't think the sum for which their credit would have to be pledged is as large as you suppose for I don't see any necessity of adopting such a gigantic scheme as Giffen's, \& in the next place I think that the chances of loss to the English taxpayer if a proper scheme of land purchase be adopted is extremely remote. Giffen says that Ireland has been overtaxed. I do not pretend to be a financier but I believe that those who are financiers agree that something would have to be returned each year to Ireland by England out of the Customs \& Excise duties. If by any chance Ireland, i.e. the Irish Exchequer not the Irish tenants, failed in any year to pay up the full amount due upon the land purchase transaction for interest \& sinking fund surely it would not be very difficult for England to pay herself the deficit by simply abstaining from sending over so much of the rebate out of customs duties to Ireland."

Chamberlain shook his head, said I might be right but he feared that the English taxpayer would be hostile \&c. \&c. "Well", said I, "I have been hearing a deal about this hostility of the British taxpayer, you yourself Mr. Chamberlain will remember that you wrote to me saying that a bitter anti-Irish feeling might at any moment be aroused in England but I confess I don't yet see any evidence of it. The elections since the General election certainly lend no support to the theory that the anti Irish feeling is rampant in England." "My dear Sir", said Chamberlain, "these elections do not prove anything. Nothing was explained to the Electors." I replied, "you are correct if you mean to convey that the sharp details of a definite scheme were not explained but surely the very fact of Mr. Gladstone having spoken as he spoke in 
Midlothian, ${ }^{334}$ followed as his speeches were by the 'Hawarden Kite' on the subject of Home Rule \& followed as this again was by persistent paragraphs in the newspapers to the effect that Mr. Gladstone was engaged in elaborating a scheme of land purchase \& of Home Rule for Ireland, was quite sufficient to arouse the anti-Irish feeling if it had any existence in England \& yet we find that all the re-elections have been favourable to Gladstonian candidates."

Chamberlain pooh-poohed my view, said he was persuaded that Englishmen would never agree to pledge their credit for buying out Irish landlords \& said he believed he would have to leave the Cabinet.

"But", said I, "if you go where will you go?". Chamberlain replied, "I don't conceal from myself that if I do go I must work with the Whigs." "Well Mr. Chamberlain", said I, "I don't pretend to understand your affairs as well as you do but I must say that if you elect to stable your horses in the Whig stalls I think you will find that the atmosphere will not agree with them. The motive power of your political mind is diametrically opposite to that which moves the Whigs \& I cannot see how an alliance between you \& the Whigs can last long with advantage or comfort to you. Don't create a big line of cleavage in the Liberal party merely for the sake of theorectic danger which you apprehend in the financial part of the Gladstone policy. At least satisfy yourself that there is a real practical risk before you take so serious a step as to resign."

Chamberlain smiled again, said he would not do anything rash \& then we parted, he asking me at any time I happened to be in the House of Commons to come down to his room to discuss matters with him.

On Tuesday morning (9th March) I called on Lord Spencer. He at once entered upon a discussion of details of land purchase schemes \& asked my opinion on several points, for example as to whether I thought a voluntary or a compulsory scheme would be more satisfactory \& workable, as to what could be done to deal with the head rents to which landlords' estates in Ireland were frequently subject, as to whether the gross or the nett rent should be taken as the basis for purchase \&c. I gave him my views on these several points and I think he was disposed to agree with them. Incidentally he mentioned that as regards his own estates in England he had not got his accounts checked over for 20 years and he found that the average annual deduction from

\footnotetext{
${ }^{334}$ The speech was delivered at the Music Hall, Edinburgh: The Times, 25 November I885, pp. II, I2.
} 
his gross rental was 34 per cent, of which only $43 / 4$ per cent was for agency fees, the bulk of the deduction was for money paid for erecting or repairing farm buildings on the estate. The average deduction on Irish estates is only about $\mathrm{I} 5$ per cent.

He said that his views as to Home Rule had undergone great changes since he left Ireland \& that some two or three months ago, finding that such was the case, he thought it right to send a letter to Sir Robert Hamilton telling him of his altered views \& that he did so because he had while in Ireland worked so cordially with Hamilton \& their views had always agreed. To his surprise he received a letter in reply from Sir Robert Hamilton which shewed that while his, Lord Spencer's, views had undergone modification, Sir Robert had without any communication with him come round to just the same opinion as Lord Spencer had arrived at. ${ }^{335}$

After a talk of about an hour's duration Lord Spencer asked me to write for him a memorandum on land purchase embodying what I had said to him. I said that I would gladly do so but that it was right he should know I was drawing up a memorandum on the subject for Sir Charles Russell, the Attorney General, which he (Sir C. R.) intended to forward to Mr. Gladstone \& that therefore he, Lord Spencer, should not be surprised at the similarity of the views expressed in the two documents.

Late in this day I saw the Attorney General \& told him about Lord Spencer's request that I should write the memorandum \& the Attorney then said that under these circumstances my best plan would be [to] write the memorandum for Lord Spencer \& let him submit it to Mr. Gladstone. ${ }^{33^{6}}$

I saw John Morley \& told him the result of my interview with Chamberlain \& he expressed himself not surprised -

Morley, "I shall tell you now sub sigillo what occurred last evening. Chamberlain tried to pump one after another three subordinate members of the Government to see whether he would be likely to detach them from the ministry if he should resign. His query was, "If Mr. Gladstone should bring in a Home Rule bill what will you do", \& it appears that each of the three made the same answer, "I shall stick by Gladstone." I said that my own view is that Chamberlain will not resign \& Morley said "I think so too".

\footnotetext{
$6 \mathrm{o}-6 \mathrm{r}$.

${ }^{335}$ See Document 32; Spencer to Carnarvon, 5 August i886: CP, Add MS 6o83o, fos

${ }^{336}$ See Fottrell to Spencer, io March I886: AP, Add MS 77152.
} 
2I March

I prepared the memorandum for Lord Spencer \& forwarded it to him on the $\mathrm{II}^{\text {th }}$ inst. It was a rather elaborate document. ${ }^{337}$

I received from Lord Spencer the following reply,

I4 March 86

\section{Dear Mr. Fottrell}

I have read over your paper carefully and sent it on to Mr. Gladstone.

I was so busy yesterday that I had not time to read it. It is a valuable paper and tackles several of the most difficult problems.

I shall not now go into it at length. The immediate reduction to the tenant is very large. At the same time you give the Irish Authority a large benefit for 66 years and after that an immense fund.

Your proposals for dealing with Head rents, Crown rents \&c. are very well worthy of consideration.

The paper will be very useful and gives a new mode of handling the subject.

There are two others ${ }^{33^{8}}$ already under discussion.

$$
\begin{array}{r}
\text { yours truly } \\
\text { Spencer. }
\end{array}
$$

I wrote to John Morley telling him of the memorandum \& saying that if it was not [to] be printed for the Cabinet I could let him have a manuscript copy if he wished for one. He replied,

I7 March 86

My dear Fottrell

The memo is now in the press. ${ }^{339} \mathrm{I}$ understand that it has excited much interest in high places. I have told Lord Spencer that you would like a proof of it \& will certainly send you one if it be possible.

\footnotetext{
${ }^{337}$ Fottrell listed the fourteen points made in his paper: see 'Confidential. Land Purchase. Memorandum of G.F.', in March i886: GP, Add MS 44632, fos I77-184. For original manuscript, see AP, Add MS 77324, and Fottrell to Spencer, I I March i886: AP, Add MS 77152.

${ }^{338}$ For schemes proposed by Chamberlain and Gladstone, see CAB 37/18/22, CAB $37 / 18 / 27$.

${ }^{339}$ 'Confidential. Ireland. Land Purchase Scheme. Summary of Memorandum dated March in 1886', i6 March I886: CAB 37/18/29. See also his 'Confidential. Landed Estates Court. - Report and Memorandum of G.F.', I7 March 1886: AP, Add MS 77324.
} 
We have plenty of trouble on hand \& ahead. Hav'nt we?

$$
\begin{aligned}
& \text { yours truly } \\
& \text { John Morley. }
\end{aligned}
$$

\section{April}

Chamberlain \& Trevelyan's resignations were accepted a few days ago. Chamberlain is replaced by Mr. Stansfield ${ }^{34^{\circ}}-$ Trevelyan by Lord Dalhousie. ${ }^{34+}$

Gladstone has announced that on the $8^{\text {th }}$ instant he will move for leave to introduce a bill for the future government of Ireland, i.e. the

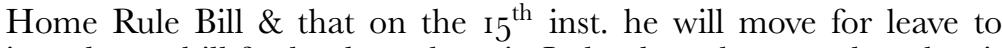
introduce a bill for land purchase in Ireland, so that not alone has it come to pass that land purchase will not be dealt with in priority to Home Rule, but it has dropped into a secondary place while Home Rule occupies the post of honour. I have been looking over the note which I wrote in this diary on 16 February last as to the relative positions of Home Rule \& land purchase as measures to be dealt with promptly \& I see that my forecast was not very wide of the mark.

\section{April}

Poor old Forster, late Chief Secretary for Ireland, died on last Monday. His death has not caused even a ripple on the political waters. It is strange how fast we live. Seven or eight years ago he was a possible Prime Minister. Then in an evil moment for himself he took the post of Irish Chief Secretary. He shewed doggedness \&, in my opinion, stupidity in his action as Chief Secretary. He imprisoned Parnell \& John Dillon \& about I30o 'suspects' ${ }^{342}$ or as he called them 'village ruffians' \& at the end of about a year England found that the game was not worth the candle, Forster was recalled and in spite of all the predictions that he would ruin the Liberal Government by reason of his recall, he seems poor fellow to have ruined only himself. I have no reason to love him for indeed he did not treat me too well as he, in the House of Commons, to save himself invented a conversation between me \& him which never took place, \& yet I believe the poor old fellow to have been in the main honest. ${ }^{3+3}$ He was pigheaded \&,

\footnotetext{
${ }^{34^{\circ}}$ Sir James Stansfield (I820-I898), Lib. MP for Halifax (1859-1895), President of the Local Government Board (I87I-1874, I886), radical and home ruler.

${ }^{341} \mathrm{John}$ William Ramsay (1847-1887), thirteenth Earl of Dalhousie (1874), Lord-in-Waiting in ordinary to Queen Victoria (I880-I885), Secretary of State for Scotland (I886).

${ }^{342}$ Between March I88I and July I882, 955 persons were arrested and imprisoned under the Protection of Person and Property (Ireland) Act (44 \& 45 Vict., c. 4): Ball, 'Policing the Land War', p. 22.

${ }^{343}$ See appendix, pp. 323-324.
} 
like most Englishmen who come over here, he assumed as an axiom that he knew more about Ireland than any of us who had lived in Ireland during all our lives.

I5 April

Gladstone on the $8^{\text {th }}$ instant introduced his Home Rule Bill. ${ }^{344}$ The scene was one of wild excitement. The Irish members arranged on the previous night that in order to make a goodly show of their strength they would go to the House very early in the morning so as to secure seats. They began to arrive at half past five o'clock in the morning and before 9 o'c they had practically all secured their seats. The members of the House number 670, while the House is constructed to accommodate only about 430 . The eagerness to secure seats was such that the hitherto unprecedented course was followed of placing chairs on the floor of the House for members.

Gladstone was received outside the House with marvellous enthusiasm. The newspapers state that: Crowd between Downing St and the House of Commons was the largest ever seen \& that even the house tops were filled with people. A deafening cheer was raised as Gladstone drove through the mass of people assembled. On his entrance into the House of Commons the Irish members rose en masse and the Liberals caught the contagion \& a mighty cheer such as is said was never before heard in St Stephens greeted the veteran statesman who was about to unfold his scheme for conferring legislative freedom upon Ireland. He spoke for 3 hours \& 25 minutes and at the end he was fresh as a May morning. ${ }^{345}$

Gladstone was followed by Colonel Waring, ${ }^{34^{6}}$ one of the rag-tag of the Orange faction, \& the contrast afforded by the two men set the House of Commons into a roar of laughter \& consequent good humour. Trevelyan spoke against the Bill \& unfolded his own plan, which is to establish County Boards in Ireland instead of a Central Legislative body. His speech was rather viperish \& it reflected upon Lord Spencer for sticking to the Cabinet. Parnell followed Trevelyan \& gave him a very rough handling, contrasting Lord Spencer's dogged pluck in remaining at his post with Trevelyan's pusillanimity in running away from his. ${ }^{347}$

\footnotetext{
${ }^{344}$ Bill to Amend Provision for Future Govt. of Ireland: PP I886, II, 46r.

${ }^{345}$ See Hansard, CCCIV, cols I036-I085. Fottrell listed the forty provisions of the bill.

${ }^{346}$ Colonel Thomas Waring (1828-1898), Con. MP for Down North (1885-1898), Grand Master of the Loyal Orange Institute of England (1892-I898); Hansard, CGGIV, cols I085I089.

${ }^{347}$ Ibid., cols I IO4-II34.
} 
Chamberlain moved the adjournment of the debate $\&$ on the $9^{\text {th }}$ April he spoke. His speech opened badly. He tried in explaining his reasons for leaving the Cabinet to disclose not only what had taken place in the Cabinet in relation to the Home Rule Bill but also what had occurred in relation to the Land Purchase Bill, a bill which had not yet been introduced. Gladstone at once pounced on him \& stated that he had no permission from Her Majesty to allow Mr. Chamberlain to divulge Cabinet secrets relating to a bill not yet drawn. Chamberlain was plainly quite put out \& his speech was in my opinion a disjointed one. His object was to do as much damage as he could to the Home Rule Bill. His criticisms were in the main a declaration against the removal of Irish members from Westminster, \& a declaration that such removal would lead the Irish Legislature to repudiate the obligation of contributions for Imperial purposes provided for by the Bill. So far, he made a tolerably effective speech but he then proceeded to develop his own plan which was certainly a sufficiently comical one. He proposed to pass an act staying all evictions in Ireland for 6 months \& thereupon to establish a Commission to enquire into the relations between England \& Ireland with a view to further legislation. Meanwhile he proposed to saddle the Irish landlords on the Imperial Treasury for their rents.

There were just a few initial objections to these proposals. First, that the Right Honl. gentleman could not possibly pass through the House of Lords, \& probably not through the House of Commons, a bill suspending evictions for 6 months. Secondly, if he did succeed in doing so \& in starting his Commission of enquiry that of course no one in Ireland would allow the Commission ever to finish its labours, the Irish landlords would receive their rents from the Imperial Exchequer while the Irish tenants would pay no rents at all.

Healy followed Chamberlain \& made an extremely able speech in support of the Bill.

The Marquis of Hartington opposed the Bill with tooth \& nail. His argument was that the strict maintenance of law \& order was the only panacea for Ireland \& that it was most dangerous to concede any extension of local freedom. He said that Gladstone had brought a disaster upon the Empire by bringing forward his Bill because it was now impossible to undo the mischief \& Gladstone's scheme would be henceforth the irreducible minimum of the Irish demand.

John Morley followed Hartington \& made a strong speech in favour of the Bill. Lord Randolph Churchill opposed the Bill but confined himself to a criticism of details \& did not pledge himself against Home Rule..$^{34^{8}}$ Sir Charles Russell, the Attorney General, supported

${ }^{34}{ }^{8}$ Ibid., cols II8I-I222, I238-I278, I317-I344. 
the Bill and in doing so quoted Lord Grey, ${ }^{349}$ Charles Fox, ${ }^{350}$ \& other Whig statesmen of the Union period to shew that the leading Whig politicians of that day were opposed to the Union. ${ }^{35 r}$

The House was greatly impressed by a speech in favour of the Bill by Mr. Whitbread, ${ }^{35^{2}}$ a member of the Whig section \& who is greatly respected \& trusted by the Whigs. His speech was a very able \& dignified one.

Sir W. Harcourt, Chancellor of the Exchequer, made a rattling speech which threw great ridicule on the alternative proposals put forward by Trevelyan, Chamberlain \& Lord Hartington, all of whom agreed in opposing the Bill but no two of whom agreed as to the scheme which ought to be substituted for that put forward by the Government. ${ }^{353}$

Mr. Goschen bitterly attacked the Government proposals. Sir Mich. Hicks Beach also assailed the Bill but his speech was rather weak.

Gladstone wound up the debate with a speech which it was admitted on all hands was a most brilliant reply and then at five minutes past one o'clock on Wednesday morning the I4 April I886 the Home Rule Bill for Ireland was read a first time, no division having been challenged on Gladstone's motion for leave to introduce it. ${ }^{354}$

Now I wish to chronicle the state of public opinion which followed Gladstone's speech. For the first two days there was undoubted despondency among Liberals \& it was freely said that the Government was certain to be defeated at a very early stage of the Bill. Gradually opinion began to veer round and after a few days the date of the disaster prognosticated for the Government was shifted from the first reading to the second reading of the Bill. Now the date seems to be again adjourned, for most men say it will be carried by a substantial majority. In example, Healy laid me one sovereign to two sovereigns that the Bill will go through its second reading with a majority of $5^{\circ}$.

${ }^{349}$ Charles Grey (1764-1845), second Earl Grey (I807), Whig MP for Northumberland (I786-1807), First Lord of the Admiralty (1806), Foreign Secretary (1806-I807), Prime Minister (I83I-I834).

$3^{3 \circ}$ Charles James Fox (I749-1806), Whig MP for Midhurst (I768-I780), for Westminster (I780-1783, I785-1806), and for Kirkwall (I784-1785), a lord of the Treasury (I772-1774), joint Secretary of State (I783), Foreign Secretary (1782, I806).

${ }^{35^{1}}$ Hansard, CGCIV, cols I344-1364. Russell drew particular attention to Chamberlain's views as articulated by Fottrell in the Fortnightly Review: Hansard, col. I352.

${ }^{352}$ Samuel Whitbread (I830-I9I5), Chairman of Whitbread Brewery, Lib. MP for Bedford (1852-1895), home ruler; Hansard, CCCIV, cols I396-I406.

${ }^{353}$ Ibid., cols I439-I458. Harcourt also forced Chamberlain to admit that he had not written the Fortnightly Review article.

${ }^{354}$ Ibid., cols I458-I482, I5I8-I550, and see Bill to make amended provision for Sale and Purchase of Land in Ireland: PP I886, V, I93. 
I do not find that many men are so sanguine on the subject as Healy, usually the number spoken of as a probable majority is between 5 \& I5.

On Friday the $16^{\text {th }}$ April I886 Gladstone introduced his Land Sales \& Purchase Bill in a speech which was considered a more eloquent effort than that which he put forth when introducing the Home Rule Bill. ${ }^{355}$ It was mainly a historical retrospect with the object of shewing that England had for centuries bolstered up the system of Irish landlordism, \& that therefore she had contracted obligations towards existing landlords in Ireland which she ought to recognise by allowing her credit to be used to raise money for the purpose of buying them out.

He states that the sum to be borrowed on such credit was not without further sanction to exceed 50 millions sterling.

The essence of the Land Bill is that every Irish landlord can compel the Irish State to buy him out, the rate of purchase being usually 20 years' purchase of the nett rent, in some exceptional cases 22 years' purchase of the nett rent, while power is reserved to the Land Commission to reduce these rates if on investigation they consider such rates excessive. On a sale being effected, the tenants are to become owners of their holdings subject to their paying for 49 years instalments, representing four per cent on the purchase money of the gross rent, thus giving them usually a reduction of 20 per cent less by the additional taxes which the tenant as owner would become liable to, while the Irish State would be liable to the Imperial Exchequer for the instalments for 49 years, representing only 4 per cent on the purchase money of the nett rent, so that the Irish State would have a premium of 20 per cent on the annual instalments less by the cost of collection.

In my opinion the Land Purchase Bill is not at all as satisfactory a measure as might have been devised and I find that both John Dillon \& E. Dwyer Gray both consider that my plan of making the tenant pay a perpetual, \& the Irish State a terminable rent charge of $£ 4$ per cent on the purchase money of the nett rent would have been better both for the Irish tenants and for the Irish State.

Sir Robert Hamilton is of the same opinion. I hear that the reason why the Cabinet did not adopt my suggestion was that it was strongly represented to them by certain northern Liberals that the Ulster tenants would very much prefer a system which would at the end of a certain number of years leave them free of rent, even although their immediate reduction of rent might be less.

${ }^{355}$ Hansard, CGCIV, cols I778-I8II. 
Both Gray and John Dillon consider that the real explanation of Gladstone's plan is that he wants to show that the Irish State will have a good revenue, so as to satisfy Englishmen that the Irish State will fulfil its financial engagements to England. Gray considers that Gladstone's proposed contribution from Ireland to England under the Home Rule Bill is more than Ireland could possibly continue to pay.

John Dillon tells me that Parnell's mot d'ordre as regards the Land Purchase Bill is for the Irish party neither to praise nor to condemn it, but to leave it to the Tories to oppose its second reading if they are foolish enough to do so \& that then the English politicians of every shade would become disgusted with the unreasonableness of the Irish landlords. I think that this is prudent on Parnell's part.

Dillon also told me that Parnell is quite resolved that either the provision in the Home Rule Bill declaring that no members shall be sent from Ireland to Westminster shall be adhered to, or else that the full present number (IO3) of Irish members must have seats in the Imperial Parliament, in which case he believes that the struggle in Westminster would continue for 3 or 4 years more \& that then Mr. Chamberlain \& his friends would insist upon that which they now oppose, viz. the retirement of Irish members from the Imperial Parliament.

Sir Robert Hamilton said to me on yesterday that he believed every day was improving the chances of the Home Rule Bill \& that every day was lessening those of the Land Purchase Bill.

\section{April}

John Morley, the Chief Secretary, came to Dublin this morning and he sent me a letter stating he would wish to see me at the Castle. I went up to him and had an hour's chat. Dr. Patton ${ }^{356}$ of the Daily Express was with him when I arrived \& I waited till he left.

We discussed the Land Purchase Bill of which he asked me my opinion. I told him that I considered it was not in its present shape a workable measure because I had reason to believe that the tenants would not consent to the Irish State deriving such an income as 20 per cent from every purchase \& that Dillon \& Dwyer Gray took the same view. He admitted that the reason for adopting the line laid down in the Bill was partly information received from the north of Ireland that the Presbyterian farmers would resent being made not proprietors but tenants of the Irish State, \& partly because Gladstone wished to show that the Irish state would derive a good revenue from the land. He

\footnotetext{
${ }^{356}$ George Valentine Patton (I836-I898), editor of the Dublin Daily Express (I873-1898) and Dublin correspondent for The Times (I866-I898).
} 
seemed to think however that if the Bill ever reached the Committee stage it might be altered to my plan.

He considers that the Home Rule Bill will pass not only a second reading but that it will in all probability pass through all its stages in the House of Commons; that it will then go up to the Lords where it will be at once rejected, that then the probable course will be an Autumn Session in which both the Home Rule Bill \& the Land Bill both (probably considerably modified) would be again considered \& both sent up to the Lords, \& if then rejected that a dissolution would most likely take place. All this however he said was problematical as nothing had yet been definitely decided.

We discussed Chamberlain's attitude. He said that all politicians were surprised to find what a small following Chamberlain had. I said it seemed that Chamberlain's probable course would be to concentrate his strength upon opposing the Land Purchase Bill \& relax his opposition to the Home Rule Bill. This view, Morley said, he thought would probably prove to be correct.

Morley expects the Home Rule Bill to pass its second reading by a majority of between 20 \& 30 .

We spoke about the big meeting at Newcastle. He told me that when Lord Spencer saw the dense crowd which filled the building in which the meeting was held, he turned quite pale \& was very nervous \& turning to Morley that he said "I don't know what to do. This is a scene such as I have never witnessed. I have spoken in the House of Lords \& I have spoken at agricultural meetings after a farmers' dinner but I never spoke to a crowd like this \& I am quite put out." Morley said "Don't be alarmed Lord Spencer, you will find it far easier to speak to an enthusiastic crowd like this than to address the House of Lords or the House of Commons", \& added Morley, "he then went on to the platform \& he was cool as a cucumber \& spoke with great dignity \& self possession. His speech had \& will have very great weight." ${ }^{357}$

Morley asked me what answer I would give to several points which Chamberlain had made against the Home Rule Bill \& he took note of the answers so as to use them in a speech which he is to deliver in Glasgow on next Friday. ${ }^{35^{8}} \mathrm{He}$ is much more cheery than when I last saw him which is a good omen. He tells me that the brunt of the work preparing the Home Rule \& the Land Purchase Bills fell on him \& on Gladstone \& Lord Spencer. The latter is, he says, a capital man at 'collar work', that he can sit down \& work hour after hour. He has a

\footnotetext{
${ }^{357}$ The meeting was held at Newcastle Town Hall on 21 April I886: The Times, 22 April I886, p. 6.

${ }^{35}{ }^{8}$ It was addressed to the National Liberal Federation of Scotland at St Andrew's Hall, Glasgow, on 30 April 1886: The Times, I May 1886, p. 9.
} 
very high opinion of Lord Spencer's high character \& pluck. "Believe me", said he, "it needs a deal more pluck for Lord Spencer to do as he is now doing, setting defiance to all the opinions of his own caste \& of his social friends, than it did to run the risk of his life over here from the knife or bullet of the assassin."

$3^{\text {rd }}$ May

On last Friday morning (30 April ı886) I received from Thomas A. Dickson, formerly MP for Tyrone, a letter stating that Mr. Shaw Lefevre, ${ }^{359}$ the newly returned MP for Bradford \& formerly Postmaster General in Gladstone's last Administration, had just arrived in Dublin \& that he would call on me at my office at I2 o'c.

Both Shaw Lefevre \& Dickson came at the appointed hour \& we had an hour's conversation mainly about the Home Rule Bill.

Shaw Lefevre's opinion is that a delegation of 20 or 25 members from the Irish Legislature, as suggested by me, would obviate the difficulty raised by many of the radicals to the provision in the Bill which enacts that Ireland shall not send members to Westminster, but he considers that even this delegation should not be sent until the expiration of 5 years \& not even then unless the Irish Legislature by a majority decided in favour of sending them. He argues with Mr. Whitbread MP in thinking that both for Ireland \& for England it would be better to have a few years of separation during which Irish statesmen could devote all their energies to the work of 'constructing' in Ireland a proper system of government.

He told me with what I regarded as somewhat unusual frankness in a Cabinet Minister of what occurred in the Cabinet in last May \& June. For example, he told me that when Gladstone on the ${ }_{15}$ May I885 announced in Parliament the resolve of the Cabinet to reintroduce "some valuable and equitable provisions contained in the Crimes Act" there had not up to that moment been any resolve arrived at, and also that in the division which took place in the Cabinet on the question of whether or not any provisions of the Crimes Act should be renewed all the Peers in the Cabinet voted for the renewal \& all the Commoners against.

He thinks that the Land Purchase Bill may pass but that the English people will need to be satisfied that not more than 50 millions will be needed. I suggested that all farms over $\mathcal{E}$ Ioo rental might be excluded from the Act. This would afford some limit.

John Dillon MP spent last Saturday evening (I May I886) with me. We discussed the Home Rule \& Land Purchase Bills. He approves

\footnotetext{
${ }^{359}$ George Shaw-Lefevre (I83I-I928), first Baron Eversley (I906), Lib. MP for Reading (I863-I885) and for Bradford Central (I886-I895), Postmaster-General (I884-I885).
} 
of Shaw Lefevre's suggestion that there should be a period of some years during which no representation of any kind should be sent by Ireland to Westminster. He is not in favour of reducing the number of representatives in the Irish Legislature to 103 of the second order \& $5^{\circ}$ of the first order. He thinks that the numbers contained in the Home Rule Bill [are] on the whole preferable. At first he was disposed to think that the smaller number would be better, but Wm. O'Brien MP pointed out to him that a House numbering 153 in all would rarely have in attendance more than one half of this number \& that with so few a number of members present as 80 or 90 the assembly would scarcely command respect as a deliberative body.

He would not vote for an alteration in the Bill providing for an immediate dissolution on the passing of the Act.

As regards the Land Purchase Bill, he thinks that on the whole the proposal to leave to the Irish Land Commission the power of fixing the price to be paid in every case would be best for the Country.

He would allow Judge O'Hagan ${ }^{360} \& \mathrm{Mr}$ Litton $^{361}$ to continue as Commissioners \& even to allow Mr. Lynch \& Mr. MacCarthy ${ }^{362}$ to continue as such if the Irish party were allowed to nominate 3 others. As two of these three he suggested myself \& Thomas A. Dickson.

\section{June}

The division on the second reading of the Home Rule Bill is now at hand. It may take place tonight or possibly it may not be taken till next week. The debate began on the Ioth May. The fluctuations of opinion as to the chances of the Bill passing a second reading have been remarkable. A few days before the debate began Timothy Healy MP took from me a bet of 2 sovereigns to one that the Bill would not pass by a majority of $5^{0}$. A week after the debate began odds were freely laid that the Bill would not pass a second reading at all. At the end of another ten days or fortnight 5 to 2 were quoted as the odds in favour of the Bill \& now its defeat seems almost certain.

At first the Conservative party kept a prudent silence, leaving it to Lord Hartington to lead the opposition to the Bill \& egging on Mr. Chamberlain \& his following to support Lord Hartington. Suddenly

\footnotetext{
${ }^{360} \mathrm{John}$ O'Hagan (I822-I89o), Judicial Commissioner of the Irish Land Commission (I88I-I889), nationalist poet and supporter of Irish home rule.

${ }^{361}$ Edward Falconer Litton (I827-I890), Lib. MP for Co. Tyrone (I880-I88I), land commissioner (I88I-I889), Judicial Commissioner of the Irish Land Commission (I889I890).

${ }^{362}$ John George MacCarthy (I829-I892), Lib. MP for Mallow (I874-I880), subcommissioner of the Land Act (I88I-I885), land purchase commissioner (I885-I892), author of works on Irish history and the land question, advocate of 'tenant-right'.
} 
Lord Salisbury made a pronouncement outside of Parliament shewing that if the Bill were defeated it was the Conservatives \& not the Whig or Radical malcontents who would seize the spoils of victory \& declaring as the Conservative policy "20 years of firm \& resolute government for Ireland" and the deportation of a million of the Irish population to Manitoba. ${ }^{363}$

This pronouncement exercised a damping effect upon the courage of Lord Hartington's followers \& more thoroughly damped the ardour of Mr. Chamberlain's supporters, \& the prospects of the Bill rose. Lord Hartington objects to the Bill in toto. Mr. Chamberlain objects to the provision contained in its 24 [th] clause which enacts that Ireland shall not send members to Westminster, rather a strange objection coming from the man who so late as the I2 March regarded the getting rid of the Irish members as the main reason which would induce the English people to consent to Home Rule. Notwithstanding the opposition of Hartington \& Chamberlain it seemed very probable that the Bill would pass its second reading, but a couple of days ago a meeting of Chamberlain's followers was held in Committee room no. I5 and Chamberlain had provided himself with a letter from John Bright announcing the intention of that old Tribune of voting against the second reading. ${ }^{36_{4}}$ The effect of this letter was immediate \& striking. Men who had been shivering on the brink of opposition made up their minds to take the plunge when they found that they would have John Bright as a fellow plunger and by a majority of the meeting it was decided that they should vote against the second reading.

June 9

On Monday night, the $7^{\text {th }}$ inst., the division took place \& the Bill was defeated by a majority of 30 . For the second reading there voted 3II including 85 Parnellites. Against it there voted 34I which number included 93 nominal Liberals \& radicals. The majority comprised among others Chamberlain, Lord Hartington, Sir Henry James, Trevelyan, Leonard Courtney, Goschen \& John Bright.

I saw Sir Robert Hamilton today. He was summoned to London on Saturday last. He told me that he spent Sunday with Mr. Gladstone \&

\footnotetext{
${ }^{36} \mathrm{O}$ On 15 May, Salisbury told the National Union of Conservative Associations at $\mathrm{St}$ James's Hall that the effect of sending 'a large proportion of the inhabitants of the congested districts to Manitoba ... would be magical upon the social condition of the Irish people': The Times, I7 May I885, p. 6.

${ }^{36}{ }_{4}$ John Bright (I8I I-I889), Leader of the Anti-Corn Law League (I838-I846), Lib. MP for Durham (1843-1847), for Manchester (1847-1857), and for Birmingham (1858-1885). For Bright's letter to Peter Rylands MP, the Liberal Unionist candidate for Burnley, see The Times, 26 June i886, p. 9.
} 
that the old man was firm as a rock \& resolved to budge not an inch but to fight to the bitter end for his plan of Home Rule. Gladstone is thoroughly master of all the details of the Irish question \& Sir Robert said that he found he had next to nothing to post the veteran statesman on. Sir Robert was present in the House of Commons during the debate on Monday night. He said he would not for an extra year of life have missed being present. Parnell's speech was in his opinion a masterly statement \& he says that if Parnell had spoken a couple of nights sooner he (Sir Robert) believes that the Bill would have passed its second reading. Gladstone's speech was in Sir Robert's opinion a splendid effort. He tells me that Chamberlain looks anything but comfortable. He writhed under Gladstone's contemptuous allusions to him. ${ }^{3{ }^{65}}$ A dissolution is inevitable. The ministerialists are badly off for money \& candidates. Sir Robert mentioned that he could not have believed what bitterness now exists in London 'Society', \& all the hangers on of Society are absolutely savage in their denunciation of Gladstone \& Home Rule \& any man who ventures to support Home Rule is ostracised from London Society life. This I regard as a good sign. It marks the cleavage between classes, \& when a measure comes in England to be regarded as 'the people's cause' it is sure to win.

Terrible riots took place last night in Belfast. They read like the Gordon riots. I think that the police in Belfast were not well handled. I50 extra men have been sent down today. ${ }^{366}$

\section{Dec. $5^{\text {th }}$}

I have not written a line in this diary since the day after the defeat of Gladstone's Home Rule and yet I ought to have done so for the events of the past few months have been interesting and highly instructive.

The General election took place in [July] and it resulted in the return of

\section{Conservatives / Gladstonians \\ Liberal Unionists / Parnellites ${ }^{367}$}

Gladstone at once resigned and Lord Salisbury took office as Prime Minister. His Chancellor of the Exchequer \& leader of the House of Commons being Lord Randolph Churchill while Sir Michael Hicks Beach was relegated to the post of Chief Secretary for Ireland. As soon as the Conservative Government was installed in office a savage

\footnotetext{
${ }^{365}$ Hansard, CGCVI, cols II68-II84, I2I5-1240.

${ }^{366} \mathrm{For}$ an account of the policing of the riots, see Mark Radford, "'Closely akin to actual warfare": the Belfast Riots of I886 and the RIC', History Ireland, 7, no. 4 (I999), pp. 27-3I.

${ }^{367}$ The Conservatives won 317 seats, the Liberal Unionists 77 , the Liberals I9I, and the Irish Nationalists 85 .
} 
onslaught was made in the Times and St Fames Gazette on Sir Robert Hamilton and his dismissal or transference from the office of Under Secretary for Ireland was loudly called for. ${ }^{368}$ The reason alleged by the Times for this attack on Sir Robert was the fact of his having assisted Mr. Gladstone in framing his Home Rule Bill, while the St James Gazette put forward as one of their main arguments against him that he was known to be very intimate with me, a fact which that journal stated to be a conclusive proof of his unfitness for the post of Under Secretary for Ireland. ${ }^{36}$ Under the circumstances I considered it fairer to Sir Robert to avoid his society for a while at least \& during four months I saw him only twice.

Immediately after Gladstone's resignation Parnell came over to Ireland for a few days. I called to see him at Morrison's Hote ${ }^{37^{\circ 0}}$ and in the course of conversation I said that I thought the Conservative Government would disappoint expectation by working along very quietly in Ireland instead of adopting a retrograde policy or one of an Orange complexion. Parnell replied with his soft voice \& quiet smile "my dear sir the Conservative Government cannot govern Ireland without a coercion act", "but", said I, "I feel sure they will try to avoid anything like coercion", to which Parnell's only reply was a still softer tone of voice \& a still more pronounced smile as he said "oh they cannot govern Ireland with a coercion act", \& from this little conversation I saw that Parnell's game was to render government by the Conservatives without a coercion act an impossibility. He laid his plans with quiet astuteness. He opened the new session, which began immediately on the re-election of the Conservative ministers, by laying great and prolonged stress upon the agricultural depression which undoubtedly existed in Ireland, a depression which rendered the payment of full rents, even of judicial rents almost impossible. He next introduced a bill for staying evictions by referring it to the Land Commission or County Court judges to decide whether or not the tenant was able to pay his full rent this year \& if he were proved to be able to pay in full \& if he lodged a certain proportion, I think $5^{\circ}$

\footnotetext{
${ }^{368}$ Those defending Hamilton included Sir Ralph Lingen, Sir Thomas Farrer, Henry Jephson, and John Morley who, under the signature 'M', argued that, while Hamilton was not the author of the Home Rule Bill, he had been duty-bound to lay opinions formed upon the subject of his daily work before his political chiefs: The Times, 27 July I886, p. 8; Morley to Spencer, ro August I886: AP, Add MS 76938. See also The Times, 22 July I886, p. Io; 24 July I886, p. 9; 29 July I886, p. 8; 30 July I886, p. 5; 3I July I886, p. 5; 4 August I886, p. I2; 5 August I886, p. 6; 7 August I886, p. Io.

${ }^{669}$ Hamilton was accused of having 'taken a leading part in forming the party policy of Mr. Gladstone's Irish Governments': St. Fames's Gazette, 24 July I886, p. 4; and see 21, 29, and 3 I July.

${ }^{370}$ Situated at the junction of Nassau and Dawson Streets, Dublin. Parnell was a regular guest and his party met there frequently to select parliamentary candidates.
} 
[per] cent of the rent due, the tribunal was to have power to stay the eviction on such terms as it should consider reasonable. ${ }^{37^{1}}$ The bill received the support of Gladstone \& the Liberals but it was defeated by the Conservative and Liberal Unionist vote. In the course of the debate on the second reading Sir Michael Hicks Beach threw out some hint of coercion whereupon he was replied to by John Dillon, who made [a] most impassioned speech in which he defied the ministry to do their worst and told them that they had now thrown the tenants of Ireland upon their own resources and that he would go back to Ireland to urge the Irish tenants by their own combination \& pluck to win the safety from landlord rapacity \& cruelty which the Government had denied them by opposing Parnell's bill. The speech created a most profound impression, Lord Randolph Churchill who sat on the Treasury Bench grew livid with excitement and all the newspapers agreed that the scene was one of the most dramatic ever witnessed in the House. . $^{32}$

John Dillon came back to Ireland \& forthwith a series of public meetings began at which the inability of the tenants to pay their rents in full was again \& again insisted. Meanwhile the Government had appointed General Sir Redvers Buller ${ }^{373}$ as a kind of Magisterial Dictator in Kerry so as to put an end to a horrible system of moonlighting outrages which had increased to an intolerable extent. The hopes of the landlord party were high that Buller would pacify Kerry by capturing the moonlighters and thus assist materially in [the] collection of the landlords' rent. Buller drove all over the County, a couple of parties of suspected moonlighters were captured, but soon rumours began to spread among the landlord clubs that, anxious as Buller was to capture moonlighters, he seemed to be almost still more anxious to compel the Kerry landlords to accept reasonable rents for their land instead of exacting their full demand. Gradually the rumours reached the press and it was openly said that Buller had insisted upon having ample notice sent to him whether any landlord required police aid for carrying out evictions, and that on such notice being given the General investigated the facts of the case so as to see whether the rent demanded was reasonable, and if he found that the demand was not fair he plainly told the landlord that no police aid would be given to him to enforce payment of a

\footnotetext{
${ }^{371}$ Bill for Temporary Relief of Agricultural Tenants in Ireland, and for Admission of Certain Leaseholders to Land Act, 1881: PP I886 (Sess. 2), VI, 3.

${ }^{372}$ Hansard, CCCIX, cols II9I-I207, I223-1247.

${ }^{373}$ Sir Redvers Henry Buller (I839-1908), chief of staff for Khartoum expedition (I884), Special Commissioner for Cork and Kerry (I886), Under-Secretary for Ireland (1886-I887), Commander-in-Chief in South Africa (I899-190o).
} 
rent which the tenant could not afford to pay. ${ }^{374}$ These statements caused great alarm among the Irish landlords who opened their eyes with amazement when they found that a revolution was quietly being carried out by the Conservative Government itself, upon which they had relied for protection of all their interests. Their alarm was not lessened when United Ireland published what purported to be a portion of a letter written by one of the members of the Royal Commission on the working of the Land Act ${ }^{375}$ to a friend of his in England, in which letter it was stated that Buller had given evidence before the Royal Commission and that in this evidence he had lauded the Land League as the sole protection which the unfortunate Kerry tenants had had against oppression, \& that in short his evidence was wildly revolutionary.

This announcement appeared in United Ireland about three weeks ago. ${ }^{37^{6}}$ About the same time Sir Robert Hamilton went over to London for a few days and again the abuse of him began in the Times \& St James Gazette, \& it was kept up so persistently for several days that it was plain that it was being done to order. ${ }^{377}$ On Sir Robert's return I called on him and he then told me that he had been offered \& has accepted the post of Governor of Tasmania, a post worth $£ .5000$ a year. He regarded the offer as being virtually a dismissal from his office. He was not offered the option of a pension. If he had been offered it, he said, he would have accepted it \& would have tried to get into Parliament. Sir Robert admitted that my intimacy with him had been the real cause of his unpopularity with the Conservatives, but he said that if all that he had done with me had to be done again he would pursue exactly the same course as he had followed. He said that it was a strange commentary on the strictures which had been made in relation to his intimacy with me that as soon as the Conservatives had come in to office I was one of the first men whom they had selected for an important post, he referred to the Royal Commission of Enquiry on the working of the Land Act. My connection with the body was as follows.

\footnotetext{
${ }^{374}$ For Buller's service in Ireland, see Geoffrey Powell, Buller: a scapegoat? A life of Sir Redvers Buller 1839-19o8 (London, 1994), pp. 8I-96.

${ }^{375}$ The Royal Commission on the Land Law (Ireland) Act, I88I, and the Purchase of Land (Ireland) Act, I885 was appointed on 29 September i886. For its reports, see PP I887, XXVI, I, 25, IIOg.

${ }^{376}$ See 'General Buller against the landlords', United Ireland, 20 November I886, p. 2.

${ }^{377}$ It was claimed that Hamilton's 'speedy departure from the Castle is indispensable to the restoration of "social order" in Ireland': St. Fames's Gazette, I8 November i886, pp. 3-4. See also The Times, I8 November I886, p. 9; 20 November I886, p. II; 23 November I886, p. 6.
} 
In August last I went for my vacation trip to Bavaria \& Lord Ashbourne, the Lord Chancellor, hearing that I was at Innsbruck addressed a letter to me there asking me to accept the post of Royal Commissioner on the Commission above named. I did not receive this letter and on my return to Ireland early in September I was met at the landing pier by Dunbar Barton ${ }^{37^{8}}$ (Lord Ashbourne's private secretary) who handed me a letter from Lord Ashbourne enclosing a copy of the former letter written about a fortnight before and urging me to accept the post of Commissioner. I went to the Castle next day \& on Lord Ashbourne's assurance that the Commission would not occupy much of my time I accepted the post.

My colleagues on the Commission were shortly after nominated \& their names were announced in the House of Commons as follows,

$\begin{array}{ll}\text { Lord Cowper } & \text { J. Chute Neligan QC } \\ \text { Sir James Caird } & \text { \& }\end{array}$

As a matter of fact I did not act upon the Commission because my brother ${ }^{33}$ having fallen ill, \& Lord Cowper having written to me to say that the sittings of the Commission would be continuous, and the nationalists having shewn unmistakeable signs of boycotting the Commission, I found it necessary for me to resign \& I accordingly did so. ${ }^{384}$

Sir Robert Hamilton in reply to an enquiry of mine said that he would not leave Ireland until next spring.

A few days after this interview the Irish public were mystified by the extraordinary announcement that General Sir Redvers Buller had

\footnotetext{
${ }^{37^{8}}$ Dunbar Plunket Barton (1853-1937), private secretary to Lord Ashbourne (1885-1886), justice of King's Bench and Chancery, Ireland (I900-I9I8).

${ }^{379}$ Francis Thomas de Grey (1834-I905), seventh Earl Cowper (1856), Lord Lieutenant of Ireland (I880-I882), Chairman of the Royal Commission on Irish Land Legislation (I886), opponent of home rule.

${ }^{380} \mathrm{John}$ Chute Neligan (I826-I9II), county court judge for King's County (I882-I89o), recorder of the cities of Londonderry and Cork (1890-1908).

${ }^{38}{ }^{8}$ Sir James Key Caird (I8 $\left.37-1916\right)$, entrepreneur and philanthropist, owner of the Ashton and Craigie jute mills near Dundee.

${ }^{382}$ Edward Nugent (1835-189o), sixth Earl of Milltown (I871), Lord Lieutenant of Co. Wicklow, owner of land in counties Wicklow, Queens, Kings, Dublin, and Tipperary.

${ }^{383}$ John George Fottrell (I857-1940), crown and state solicitor for Co. Meath (c.1904-1935) and co-author, with his brother, of several publications on land law.

${ }^{384}$ See The Times, I October I886, p. 7; 4 October I886, p. 6; and John J. Clancy, Six Months of 'Unionist' Rule (London, I887), pp. 36-37.
} 
been appointed Under Secretary for Ireland ${ }^{385}$ Surprise was expressed on all sides at this announcement. The national press bandied the Government on their selection of a man whose opinions were more pronounced against Irish landlords than Sir Robert's had ever been, \& the Conservative press, Daily Express \&c., seemed shamefaced \& unable to give any plausible explanation of why Redvers Buller was to be Under Secy.3.

Either of two explanations must I think be correct. Either the Government, not knowing how to get Redvers Buller out of Kerry, has adopted this course of temporarily putting him into office as Under Secy., or else, feeling that the only chance of the Conservatives keeping in office is the avoidance of coercion \& that the only chance of the avoidance of coercion is official repression of the landlords, the ministers have put Buller into office in the hope that he will frighten the Irish landlords into mitigating their demands.

John Dillon has been served with a summons to appear before the Court of Queen's Bench under the Act of Edward the 3rd to give bail for his good behaviour. ${ }^{37}$

This is in consequence of his proceedings under the United Ireland 'Plan of Campaign'. As this plan is likely to be historic I may as well shortly describe what it is. It appeared in United Ireland about three weeks ago. ${ }^{38}$ Its authors are Timothy Harrington MP \& William O'Brien MP. The object is to enable tenants to whom their landlords refuse a reasonable abatement of rent to combine together to defeat any proceedings which the landlords may adopt against the tenant or any of them. Under the plan the tenants would meet together \& resolve first upon what percentage of reduction it would be fair to demand. This being done, if the demand be acceded to well \& good, the tenants pay. If the reduction be refused the tenants again meet \& appoint a managing Committee from among themselves \& they then arrange to pay to some one or two trusted persons the amount of their rent less by the reduction demanded \& this money, when collected, is then handed by the one or two persons who collected it to some person unknown to the tenants \& unknown to any one save to the person so handing it over. The money so collected is then available for the support of any tenant whom the landlord may seek to evict

\footnotetext{
${ }^{385}$ See The Times, 30 November i886, p. 6.

${ }^{386}$ See $F$ F, I December I886, pp. 4-5.

${ }^{387} 34$ Ed. III, c. I. Normally used to deal with vagrancy, this statute enabled the Crown to prosecute defendants without need of complainant or opportunity of appeal. It was revived, after a lapse of 300 years, for use against political agitators in I883: Thomas Gerrard to William Lane Joynt (Crown and Treasury Solicitor), 30 March I883: CSO RP I883/II555.

${ }^{388}$ See United Ireland, 23 October I886, repr. Laurence Geary, The Plan of Campaign, I886I89I (Cork, I986), pp. I44-I50.
} 
and it will not be paid to the landlord until he comes to terms with the tenant, \& if any tenant behind the back of the others pays his rent to his landlord he forfeits at once all right to the contribution which he made to the tenants' collected fund.

John Dillon had under this plan collected rents on Lord Clanrickarde's estate \& on Lord Dillon's estate. The plan has been put in operation on several other estates, among others on the Ponsonby estate in the County of Cork. ${ }^{389}$ The adoption of the plan threw the Cork Property Defence Association $39^{\circ}$ into a panic \& they promptly called upon Captain Plunkett, the Divisional Magistrate in Cork, to arrest Mr. Lane $\mathrm{MP}^{391}$ while actually collecting the rents on the Ponsonby estate. Captain Plunkett was too cautious to accede to this request but he sent a memorandum up to the Castle stating the particulars of the case \& asking for the opinion of Mr. Hugh Holmes, ${ }^{392}$ the Attorney General. The opinion given was as follows,

"There is a mode by which the landlord might get hold of the money which of course is not a matter for the Government; \& I dare say the landlord will have good advice. I do not see how any action can be taken by the Executive.

\section{Hugh Holmes Attorney General"}

This opinion was by some mysterious means conveyed to the Editor of United Ireland who published it in the issue of the paper dated yesterday and the result is consternation. ${ }^{393}$ The publication must embarrass the ministry terribly because the opinion practically cuts the ground from under their feet in relation to the seizure of United Ireland, which John Dillon assures me was certainly determined on in Dublin Castle early in last week. ${ }^{394}$ The National League seem to know almost as soon as

\footnotetext{
${ }^{389}$ The Marquis of Clanricarde owned 56,826 acres at Portumna, Co. Galway; Viscount Dillon owned 83,749 acres in County Mayo; and Charles Talbot-Ponsonby held I0,367 acres near Youghal, Co. Cork.

${ }^{39^{\circ}}$ The Cork Defence Union was established in October I885, under the presidency of the Earl of Bandon, to assist landowners, merchants, farmers, and labourers boycotted by the National League.

${ }^{391}$ William John Lane (b. I849), Nat. MP for Cork East (I885-1892), trustee of Cork Savings' Bank.

${ }^{392}$ Hugh Holmes (I840-I9I6), Con. MP for Dublin University (I885-1887), Solicitor- and Attorney-General for Ireland (1878-1880, I885-1886, I886-1887), justice of Common Pleas and Queen's Bench, and Lord Justice of Appeal for Ireland (1887-1915).

${ }^{393}$ See United Ireland, 4 December I886, p. 5.

${ }^{394}$ In fact, the Chief Secretary, on the advice of his law officers, abandoned the idea of prosecuting United Ireland for publishing the Plan of Campaign: Hicks Beach to Salisbury, 3o November 1886: SAP, D2445, PGG/3I.
} 
the Law Officers themselves everything which transpires in the secret councils at Dublin Castle.

\section{Friday Dec. I7.}

On last Thursday I had a farewell dinner for Sir Robert Hamilton. He, the Most Rev. Dr. Donnelly, E.D. Gray MP, Mr. Commissioner Lynch \& others were present. Sir Robert devoted most of his time to an earnest talk with Gray. On last Monday I met Sir Robert at dinner at Father Healy's of Little Bray, ${ }^{395}$ and in the course of a conversation which I had with him on our way up from the train he told me that in his opinion Sir Redvers Buller was not an advocate for Home Rule, but that his (Sir Redvers Buller's) view was that the Irish people had hitherto seen the law used altogether in favour of the landlords \& that consequently they were disaffected, but that if they could once realise that the law would not be put in force to aid bad landlords in cruel oppression the Irish people would come to have not alone a respect for the law but also an indifference towards Home Rule. I laughed at this estimate of the Irish situation \& Sir Robert agreed that it was a very shallow one. At Father Healy's was Mr. John Mulhall, ${ }^{396}$ the private secretary of Lord Londonderry, ${ }^{397}$ the Lord Lieutenant. Mr. Mulhall was introduced to me by Sir Robert Hamilton \& we had a friendly chat on our way home \& in the course of it he promised to introduce me to Sir Redvers Buller.

On last Tuesday I dined at the house of Samuel Walker QC, formerly Attorney General for Ireland under the Gladstone Government. Sir Robert Hamilton was present \& among others Thos. A. Dickson, formerly MP for Tyrone. In the course of the evening I remarked to Sir Robert that I thought Sir George Otto Trevelyan had shewn a great want of foresight when he did not avail himself of Sir Robert's practical dismissal from the Under Secretaryship to sever his connection with the Liberal Unionists, because as Trevelyan had brought Sir Robert over from the Admiralty to Ireland \& as they were most intimate friends \& connections, the bad treatment of Sir Robert would have enabled Trevelyan to pose as a chivalrous man in resenting that treatment \& making it an excuse for abandoning his

\footnotetext{
${ }^{395}$ Rev. James Healy (1824-I894), curate and administrator of Bray (I858-I893), parish priest of Ballybrack (I893), member of the FitzGibbon-Churchill circle: Foster, Lord Randolph Churchill, p. 42, and see W.J. Fitzpatrick, Memories of Father Healy of Little Bray (3rd edition, London, I898).

${ }^{396} \mathrm{John}$ Mulhall (b. I856), private secretary to Lord Londonderry and the Earl of Zetland (I886-I892), Vice-Chairman of the General Prisons Board (I892-I912).

${ }^{397}$ Charles Stewart Vane-Tempest-Stewart (I852-I9I5), sixth Marquess of Londonderry (I884), Con. MP for Co. Down (I878-1884), Lord Lieutenant of Ireland (I886-I889), Chairman of the Ulster Unionist Council (I9I2-I9I4).
} 
untenable position as a Liberal Unionist. Sir Robert then told me that Trevelyan had not written him one single line for several months past $\&$ had not sent any message of sympathy or any expression of regret or resentment at the treatment which he, Sir Robert, had met with. He also said that he was aware that Sir George Trevelyan did feel that the Liberal Unionists were fighting a losing game.

Dickson came to me to tell me that Mr. Knipe ${ }^{39^{8}}$ the tenant farmer who had been put on the Royal Commission in my place, had been with him (Dickson) \& had said that he was very anxious to draw a separate report \& had asked Dickson for help to do it. Dickson evidently wanted me to draw it, but I said I not alone could not draw it but that I could not even give any hints about it unless I saw the evidence. Dickson promised to get me the evidence. ${ }^{399}$ Dickson also told me that he had been examined the day before by the Royal Commission \& that in the course of the examination Lord Cowper, the Chairman, asked him would it not be a good plan to enact that in every proceeding for ejectment the judge should be bound to enquire into the ability of the tenant to pay the rent sued for, \& that a decree in ejectment should not be granted if it was proved that the tenant was unable to pay. ${ }^{400} \mathrm{I}$ smiled \& asked how this differed from Mr. Parnell's Bill, which Lord Cowper's friends had aided in rejecting. Dickson said that Lord Cowper \& the other Royal Commissioners seemed quite to admit that the judicial rents of I88I \& I882 could not possibly be maintained.

On the morning of Wednesday the 15 Dec. 86 I saw Sir Robert Hamilton at the North Wall \& bid [sic] him goodbye on his leaving Ireland. No one was there to see him off except Harrel, ${ }^{401}$ the Commissioner of the Metropolitan Police, Reed, the Inspector General of the Constabulary, Sir William Kaye, ${ }^{402}$ Assistant Under Secretary, \& myself.

\footnotetext{
${ }^{39{ }^{8}} \mathrm{~A}$ Presbyterian farmer holding 500 acres at Ballaghy, Co. Armagh: The Times, 4 October I886, p. 6.

${ }^{399}$ Dissenting from the Commission's findings, Knipe recommended that the Land Commission be empowered to lower rents: Report by Mr. Thomas Knipe on the Land Law Act I88I, and the Purchase of Land Act I885: PP I887, XXVI, I24I.

${ }^{400}$ See $P P$ I887, XXVI, 25, pp. 906-910.

${ }^{401}$ David Harrel (I84I-I939), RIC officer (I859-I879), RM for Co. Mayo (I879-I883), Chief Commissioner of the Dublin Metropolitan Police (I883-I893), Under-Secretary for Ireland (1893-I902).

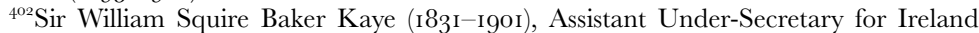
(I878-I895), private secretary to the Lord Lieutenant of Ireland (I895-I90o).
} 
On Wednesday morning John Dillon MP dined with me and we had a chat about the Plan of Campaign. He told me that he \& his staff had collected already about $f, 7000, \&$ that he expected to collect altogether about $£ 20000$ which he thought would be enough to enable the Irish party to fight the battle of the tenants. His belief is that when the English people come to realise the enormous expense, trouble \& disgrace involved in a contest to enable a man like Lord Clanrickarde ${ }^{03}$ to screw impossible rents out of his tenantry they will speedily throw Lord Clanrickarde \& his like overboard \& will insist upon some settlement being come to. John Dillon told me he was going down on the following morning to Loughrea to continue the rent collection on Lord Clanrickarde's estate.

On yesterday (Thursday) morning I went down to Newcastle West, Co. Limerick to meet Lord Devon' ${ }^{404}$ tenants in order to see if I could arrange terms of sale. I travelled home by the night train \& on arriving home at 5 am I learned that John Dillon had been arrested in Loughrea during the day. ${ }^{405}$ It appears that the magistrate there granted a warrant for his arrest on the charge of conspiracy. I should have mentioned that on last Saturday John Dillon's case was resumed before the Court of Queen's Bench \& in the course of the proceedings the Attorney General (Holmes) stated that the Plan of Campaign was distinctly a conspiracy, \& the Judges (Judge O'Brien ${ }^{406}$ \& Judge Johnson ${ }^{407}$ ) in pronouncing judgement \& ordering John Dillon to find bail himself in $£$ IOoo \& two sureties in $£ 500$ each for his good behaviour likewise said that the plan was a conspiracy.

In Loughrea John Dillon was collecting rents along with Mr. Matthew Harris MP, ${ }^{408}$ Wm. O'Brien \& Mr. Sheehy MP ${ }^{409}$ when the police broke into the house, seized all the books \& money (about fioo) which John Dillon had before him, [and] marched all the aforesaid

\footnotetext{
${ }^{403}$ Hubert George de Burgh-Canning (I832-I9I6), second Marquess of Clanricarde (I874), Con. MP for Co. Galway (1867-I87I).

${ }^{404}$ William Reginald Courtenay (I807-I888), eleventh Earl of Devon (I849), Con. MP for Devon South (I84I-I849), Chancellor of the Duchy of Lancaster (I866-I867), owner of 33,026 acres in Co. Limerick.

${ }^{405}$ See The Times, I7 December I886, p. 5 .

${ }^{406}$ William O'Brien (I832-I899), justice of Common Pleas and Queen's Bench, Ireland (1882-I899).

${ }^{407}$ William Moore Johnson (1828-I918), Lib. MP for Mallow (1880-1883), Solicitor- and Attorney-General for Ireland (I880-I88I, I88I-I883), justice of Queen's Bench, Ireland (I883-I909).

${ }^{408}$ Matthew Harris (I826-I89o), Land League organizer, representative for Connaught on Supreme Council of the IRB (I878), Nat. MP for Galway East (1885-189o).

${ }^{409}$ David Sheehy (1844-1932), Nat. MP for Galway South (1885-1900) and for Waterford city (1903-1918).
} 
gentlemen before a magistrate who remanded them for a week taking bail for each in $£$ IOO for himself \& two sureties of $£ 5^{\circ}$ each.

On this morning I saw John Dillon in bed. He came up last night. On his way to the train he was thrown from his car \& he has severely bruised his side so that he must rest for a couple of days..$^{40}$

I asked what would he \& his friends now do \& he told me in confidence that if they could not collect the rents openly they would do it by sending collectors round quietly to the tenants' houses.

\section{Dec. 25 .}

A day or two after I had seen John Dillon, he \& his co-defendants were served with a summons to appear before the magistrates at Dublin to answer for their conduct \& simultaneously, or immediately after, they were served with a notice by Sub Inspector Davis ${ }^{411}$ (their Loughrea prosecutor) that he would not proceed any further with his prosecution. I saw John Dillon on the evening of notice being served on him \& he told me that he had not made up his mind which course he \& his friends would pursue, but that his belief was that they would go down to Loughrea on the day named in the remand (which by a curious piece of stupidity on behalf of the Crown was the same day as that named in the Dublin summons) and demand a dismissal of the Loughrea proceedings or a prosecution of them.

On Thursday last, accordingly, the proceedings at the Police Court in Dublin ended in a fiasco because the Defendants did not appear \& Mr. Healy, Counsel for one of them, mentioned that the charge being one of conspiracy, \& therefore the evidence against one Deft being evidence against all, it would be singularly inconvenient to go on with the case in the absence of some of the Defts. who were in Loughrea. Accordingly the Dublin proceedings were adjourned for a week.

Meanwhile Dillon, O’Brien \& Harris had gone down to Loughrea \& a message had been sent to the supposed national magistrates to attend the Loughrea bench. Col. Nolan MP ${ }^{12} \&$ Mr. McDonagh attended, \& Mr. Radford \& Mr. Townsend, ${ }^{413}$ representing the other side of politics. Nolan, who was Chairman of the Bench by virtue of seniority, seems to have acted rather weakly. The Bench were evenly divided as to whether the case should be entered as 'dismissed' or as 'no rule' \& therefore the ruling entered was "no rule the prosecution being withdrawn",

\footnotetext{
${ }^{410}$ See The Times, i7 December i886, p. 5 .

${ }^{41 \mathrm{II}}$ William Davis (b. I834), RIC District Inspector for Loughrea.

${ }^{412}$ Colonel John Philip Nolan (1838-1912), Nat. MP for Co. Galway (1872, I874-1885) and for Galway North (1885-I895, I900-1906).

${ }^{413}$ Norman Lionel Townsend (b. I846), Sub-Inspector of RIC (I866-I886), RM (I886I9II).
} 
but on an application being made for an order to restore to Dillon the money \& book seized Nolan alleged that the Court had no jurisdiction \& refused to make any order. ${ }^{44} \mathrm{I}$ am not much of a lawyer but I should have supposed that the money \& book having been ostensibly seized as evidence for a prosecution which was withdrawn, he ought to have decided that on the withdrawal the money \&c. should be restored to the persons from whom they had been taken.

One the same day a thunderbolt fell in the political world. Lord Randolph Churchill resigned his post as Chancellor of the Exchequer. Of course, the surmises as to his reasons were various. The alleged reason was his inability as Chancellor to acquiesce in certain large increases of expenditure on the army \& navy which were demanded by Lord George Hamilton ${ }^{45}$ on behalf of the navy \& by W.H. Smith on behalf of the army. The general impression is that he resigned partly because he could not get the Cabinet to agree in putting forward a tolerably democratic scheme of County government \& partly because he did not like the Irish outlook. ${ }^{4{ }^{16}} \mathrm{I}$ had a letter today from Mr. Labouchere $\mathrm{MP}^{47}$ in which he says that the opinion in London is that Lord Hartington will now join the ministry, or failing him that Mr. Goschen will be put forward.

On the day of the announcement of Lord Randolph's resignation Chamberlain made a speech in Birmingham which I think evidences a decision on his part to get back into the Liberal ranks. ${ }^{48}$ It said that he $\&$ his friends were agreed with the Liberals on 99 per cent of their programme.

I887

Jany. 3 .

On Christmas Eve my Father met with an accident to which I did not at the moment attach so much importance as I ought to have

\footnotetext{
${ }^{414}$ See The Times, I8 December I886, p. 6; 21 December I886, p. 6; 24 December i886, p. 4 .

${ }^{45}$ Lord George Francis Hamilton (I845-I927), Con. MP for Middlesex (I868-I885) and for Ealing (1885-I906), First Lord of the Admiralty (1885-1886, I886-I892), Secretary of State for India (1895-1903).

${ }^{416}$ See Foster, Lord Randolph Churchill, pp. 30I-310.

${ }^{417}$ Henry Du Pré Labouchere (I83I-I9I2), Lib. MP for Northampton (I880-I906), proprietor of Truth, radical reformer and home ruler. Earlier, Labouchere had transmitted news of Gladstone's position on home rule to Churchill, as revealed to him in a recent letter from 'go-between' (presumably Fottrell): Labouchere to Churchill, i January i886: RCHL, I/II. I238.

${ }^{4{ }^{18}}$ Chamberlain addressed a private meeting of the Liberal Divisional Council of West Birmingham on 23 December i886: The Times, 24 December I886, p. 4.
} 
done but which has since developed very seriously. He was thrown down by a car in Sackville St and his forehead was cut across. For a few days he shewed no serious symptoms but for the last two days he has been delirious \& his condition is critical. I had arranged to be in London on Monday morning the 27 Dec. but in consequence of my father's accident I delayed leaving Dublin until that evening, when the Doctors told me that I might safely go without apprehension of any bad result during my absence. ${ }^{49}$

On Tuesday morning the $28^{\text {th }}$ Dec. I called at Gardiner Place, by appointment, on Lord Stanhope ${ }^{420}$ (whose estate I was engaged in selling to his tenants) so that he might execute the conveyances to complete the sale. I did not remember ever having met Lord Stanhope before but he reminded me that he had been a member of the House of Lords Committee in I882 which sat to enquire into the working of the Land Act of I88I \& before which Committee I was examined. ${ }^{421}$

I chatted with him on various topics, political and other, but I could not gather from him that he knew anything more of political prospects than what we all knew. His brother, the Hon. Edward Stanhope MP, ${ }^{422}$ is the Colonial Secretary \& a member of the Cabinet. Lord Stanhope asked me to call on his brother who is also his trustee \& who was up in London on that day attending the Cabinet Council which had been summoned to consider what the ministry should do consequent upon the resignation of Lord Randolph Churchill. Unfortunately, when I called at the Colonial Office Mr. Stanhope had gone to his County seat \& therefore I had no chance of learning his views.

On Wednesday the 29 Dec John Morley, Sir Robert Hamilton, Mr. Labouchere MP, Captain Waldron ${ }^{423}$ \& young Charles Russell dined with me at the National Liberal Club. Labouchere was in his most entertaining mood. He is I think almost the best if not the very best dinner companion I have ever met. He is almost more exhilarating in this capacity than poor Isaac Butt, ${ }^{24}$ than whom it would be impossible to name a more genial companion. Butt of course

\footnotetext{
${ }^{419}$ See Ff, 28 December I886, p. 6.

${ }^{420}$ Arthur Philip Stanhope (I838-I905), sixth Earl Stanhope (I875), Con. MP for Nottingham (I860-I866), owner of 2,I29 acres in Queen's County.

${ }^{421}$ Land Law (Ireland): First Report from the Select Committee of the House of Lords: PP I882, XI, I. For Fottrell's evidence (24 March I882), see pp. 219-264, and for his report as solicitor to the Land Commission (II February I882), see pp. $44^{\mathrm{I}}-44^{8}$.

${ }^{422}$ Edward Stanhope (1840-I893), Con. MP for Mid-Lincolnshire (I874-I885) and for Lincolnshire, Horncastle Division (1885-1893), President of the Board of Trade (I885I886), Secretary of State for the Colonies (I886) and for War (I887-I892).

${ }^{42}$ Francis Waldron (1853-1932), captain of Royal Artillery, brother of Laurence Waldron.

${ }^{424}$ Isaac Butt (1813-I879), Con./Lib. MP for Youghal (I852-I865), Nat. MP for Limerick (I87I-1879), founder of the Home Government Association (1870) and the Home Rule League (I873).
} 
was infinitely a greater man \& gave vastly more information in his sallies of humour than Labouchere could contribute, but the cynical playfulness of Labouchere it would be hard to beat. For four hours he kept us all in a roar of merriment. With him no man is sacred. He would scalp his grandmother for the sake of a joke \& yet it would be unjust to say that he is hard hearted or cruel. Indeed, he jokes at himself as much as he does at other people. Some of his stories about the election for Windsor, for which place he was years ago returned as member \& after which election he was by an Election Committee of the House of Commons unseated for bribery, made Hamilton stare in dazed amazement. Hamilton takes a serious view of life \& it was most amusing to watch his perplexity while Labouchere rattled away in the most audacious fashion telling how he bribed \& how he cajoled electors first, \& how he endeavoured afterwards to cajole the Commons Committee. ${ }^{425}$ Of course, Labouchere if his statements about himself were to be taken as grand serieux would be worthy of the dock, but as was truly said of him by a newspaper correspondent (I think T.P. O'Connor MP) some time ago he takes more pains to make himself out infinitely worse than he is, than most men take to make themselves appear better than they are. In truth, he is a very strong, earnest politician keenly anxious for the triumph of radical principles of government \& anxious to improve the condition of the people, but to listen to himself one would suppose he was a mere 'flaneur'. Some of his descriptions struck me as very racy. Waldron, à propos of some mention of the Duke of Marlborough ${ }^{26}$ asked him - "Is not the Duke a clever man". "Yes", said Labouchere, "very clever \& a charming fellow. I have known him \& Randolph since they were boys \& they are both charming fellows - very interesting - they are among my dearest friends - they are both members of the criminal classes - I mean that if one did not happen to be a Duke \& the other a leading statesman they would be picking pockets at the corner of a street".

He described the scene in the House of Commons in I88I when the Gladstone ministry was engaged in passing the Coercion Bill for Ireland - "Harcourt \& Parnell gave me great pleasure at that time. Parnell thought that Harcourt would lock him up in prison \& Harcourt thought that Parnell's friends would blow him (Harcourt) up with dynamite. Parnell used to ask me with a long face whether I thought the Government really meant to pounce on him when the Bill would have passed, \& Harcourt used to enquire eagerly whether I really thought there was a danger of a dynamite attack on himself

\footnotetext{
${ }^{425}$ Labouchere was elected on I2 July I 865 but unseated by a committee of the House of Commons on 25 April I866: The Times, I3 July I865, p. I0; 26 April I866, p. 7.

${ }^{426}$ George Charles Spencer-Churchill (I844-1892), eighth Duke of Marlborough (I883).
} 
personally. I used to say 'thank God another 24 hours have passed without any fresh outrage I really thought there would have been worse work before now', \& when Harcourt one day asked me home to dine with him I said 'oh no my dear Sir William I am much obliged but I really should be afraid that your cellar may be filled up with dynamite'. Harcourt got such a fright at that time that if he were now to waver in his new born faith in Home Rule I believe that the explosion of a cracker would promptly bring him to heel". ${ }^{427}$

Turning to more serious conversation, I found that Labouchere very strongly urged upon Morley that the Liberals, leaders \& followers, should not alone drop the land purchase scheme for Ireland, but that they should go for Home Rule alone as the work of the next Parliament, \& pledge themselves not to use Tory votes to carry a purchase scheme until after the passage of a Home Rule bill [or] a new Parliament should have been summoned.

Morley did not express a decided opinion, nor did any of the rest of us \& when Morley had gone Labouchere came up to me to have a few private words with me \& he urged me very strongly to use my influence with Morley to get him to fall in with the opinion which he, Labouchere, had expressed. He said, "if you can bring Morley round don't be afraid, we shall get the old man (Gladstone) to go for the plan. He will throw Catherine in", some slang expression which I had never heard before, ${ }^{428}$ but the plain meaning was that Gladstone would be able \& willing to shew that he was not bound by any declaration of his to couple land purchase \& Home Rule together.

On yesterday I wrote [to] Morley urging him not to pledge himself as Labouchere suggested, but simply to allow land purchase to fade gradually out of the Liberal programme - to go straight for Home Rule \& to allow all the pressure in favour of a purchase scheme to come from the Tories or from their Liberal Unionist allies.

On Thursday the 30 Dec. I saw Mr. Stead, ${ }^{429}$ the Editor of the Pall Mall Gazette \& remained with him for some quarter of an hour or so. He told me with a great air of mystery that since he had seen me in Dublin Parnell had sent for him \& that in his interview he (Stead) had mentioned that Captain O'Shea had called on him a few days previously \& had told him that he (O'Shea) had discovered among his letters a couple of letters from Parnell in which Parnell acknowledged that he was the originator of Chamberlain's

\footnotetext{
${ }^{427}$ 'Was there ever', Labouchere asked Churchill, 'such a timorous Jumbo?': Labouchere to Churchill, 23 December i885: RCHL i/ı. iाg9.

${ }^{428}$ Presumably a reference to Gladstone's wife, Catherine.

${ }^{429}$ William Thomas Stead (I849-I9I2), editor of the Pall Mall Gazette (I883-I89o), founder of the Review of Reviewes (1890).
} 
'National Council Scheme', which I had developed for Chamberlain in the Fortnightly Review. He said that Parnell replied there were no letters of his he was afraid of even although they had been given to Chamberlain, that it was quite true he, Parnell, had in starting the National League in I88I shadowed forth such a Council, but that he never intended it as a substitute for a legislative assembly. ${ }^{43^{\circ}}$ I incidentally mentioned that Chamberlain in speaking to me had distinctly told me he had in writing Parnell's approval of the 'heads' which Chamberlain, or rather Escott had given me as the basis of the article which I was asked to write. To my astonishment I found in the Pall Mall Gazette of the $\mathrm{I}^{\text {st }}$ inst. the statement on the opposite page. ${ }^{43 \mathrm{r}}$

Mr. Goschen has accepted the post of Chancellor of the Exchequer under Lord Salisbury.

It was announced in Saturday's (I Jany. 87) evening papers that Morley had had an interview with Chamberlain on the previous day at the Devonshire Club \& had then gone together to the Lyceum Theatre to see Henry Irving in Faust. ${ }^{43^{2}}$ I wrote in my letter to Morley asking what the meeting portends the more especially as it is stated that a conference is to take place between Morley, Chamberlain, Harcourt, Lord Herschell ${ }^{433} \&$ Trevelyan.

Jany. 6

I received a letter today from John Morley in which he says "I am much obliged for your letter \& will lay it to heart all the more as I was already of the same mind. Be sure that there is not the slightest fear of my selling the fort. I wish you could find time to jot down ever so roughly any points which you think might be useful to me in our disputation with the opponents of next week."

Jany. 7

On this morning at a quarter to I2 o'c. noon my poor father breathed his last. God rest his soul. A more kindly, innocent, unselfish man never breathed. He had not an enemy in the world. ${ }^{434}$

\footnotetext{
${ }^{43^{\circ}}$ The Irish National League was founded on I7 October 1882.

${ }^{431}$ Cutting inserted into journal: see $P M G$, I January I 887 , p. 8.

${ }^{432}$ Sir Henry Irving (1838-1905), actor credited with reviving popular interest in the plays of Shakespeare; during 1885-1887 he appeared as Mephistopheles in Wills's Faust. See also $P M G$, I January I887, p. 3.

${ }^{433}$ Sir Farrer Herschell (1837-I889), first Baron Herschell (I886), Lib. MP for Durham city (1874-I885), Solicitor-General (I880-I885), Lord Chancellor (I886).

${ }^{434}$ See $F$ f, 8 January 1887 , p. 4. Following an inquest, the car driver responsible for the incident was charged with manslaughter: $F \mathcal{F}$, Io January I887, p. 2; I5January I887, p. 6.
} 
Jany. 24

Monday

On last Friday I got a sudden summons to London on business connected with the sale of a large Irish estate. I let John Morley know that I was going over \& he asked me to go to him to lunch to have a quiet chat alone on the political situation.

I was with him on last Saturday for a couple of hours. I did not point blank ask him the result of the 'round table conference' nor did he in turn mention the result, but it was plain from his observations \& from his questions that the result might be summed up by saying that Chamberlain had seen the error of his ways \& that he would by successive \& gradual feats of oratorical gymnastics get back into the Gladstone fold \& show that in doing so he had all along been consistent.

Chamberlain was the first to make overtures for the meeting of himself \& Morley at the Devonshire Club. Morley at first refused the meeting but Chamberlain asked him to go to the Lyceum Theatre with him \& Morley fought shy of this proposal but yielded after a while. ${ }^{435} \mathrm{He}$ has since received many letters from Liberals abusing him for going so ostentatiously with Chamberlain.

Morley asked me a number of questions as to my opinion on certain points, always saying "remember I don't say that the suggestion which I put before you is my own or whether it is not".

For example, he asked me did I believe it possible to frame a scheme of purchase from Irish landlords which would be compulsory \& which would not involve pledging Imperial credit. I replied "certainly not". A successful scheme of purchase involves a reduction in the annual sum payable by Irish tenants. A reduction in such sum involves either the borrowing of money on cheap terms or the purchase on the basis of a small number of years' purchase of the rental. If the Irish bonds in which the Irish landlord is to be compelled to accept payment be bonds bearing a low rate of interest, say 3 or $3{ }^{\mathrm{I}} / 2$ per cent, they will not stand at par \& therefore the landlord will be paid in a depreciated currency, if on the other hand they bear interest at a rate which will secure that the bonds shall stand at par then the tenant cannot get a reduction in his annual payment unless the purchase be at a very low number of years of the rental.

\footnotetext{
${ }^{435}$ Morley informed Spencer that Chamberlain had pressed Hartington to join them but the latter declined, fearing that his presence might kindle distrust in the Conservative Party: Morley to Spencer, I January I887: AP, Add MS 76938; and see Michael Hurst, Joseph Chamberlain and Liberal Reunion: the Round Table Conference of I887 (London, I967), pp. I52-I56.
} 